\title{
ESTUDOS DE Bacillus thuringiensis Berliner VISANDO AO CONTROLE DE Spodoptera frugiperda (J. E. Smith)
}

\author{
Ricardo Antonio Polanczyk
}

Tese apresentada à Escola

Superior de Agricultura "Luiz de Queiroz", Universidade de São Paulo, para obtenção do título de Doutor em Ciências, Área de Concentração: Entomologia.

\author{
PIRACICABA \\ Estado de São Paulo - Brasil \\ Janeiro - 2004
}




\section{ESTUDOS DE Bacillus thuringiensis Berliner VISANDO AO CONTROLE DE Spodoptera frugiperda (J.E. Smith)}

\section{Ricardo Antonio Polanczyk}

Engenheiro Agrônomo

Orientador: Prof. Dr. SÉRGIO BATISTA ALVES

Tese apresentada à Escola Superior de Agricultura "Luiz de Queiroz", Universidade de São Paulo, para obtenção do título de Doutor em Ciências, Área de Concentração: Entomologia.

\footnotetext{
PIRA C I C A B A

Estado de São Paulo - Brasil

Janeiro - 2004
} 
Dados Internacionais de Catalogação na Publicação (CIP) DIVISÃO DE BIBLIOTECA E DOCUMENTAÇÃO - ESALQ/USP

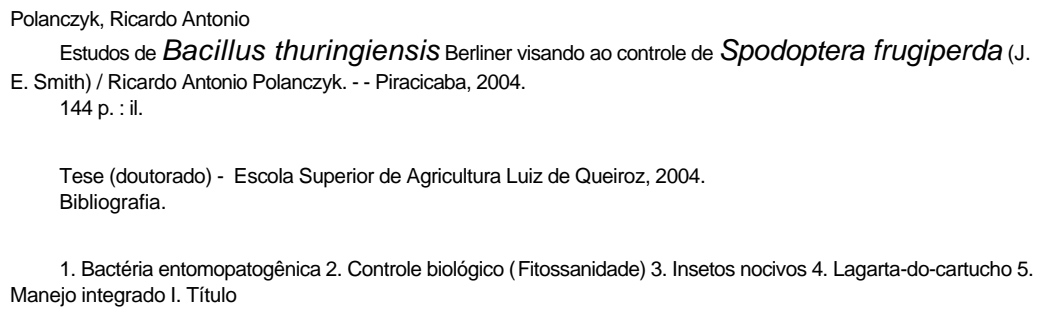

CDD 632.78

\section{"Permitida a cópia total ou parcial deste documento, desde que citada a fonte - $\mathrm{O}$ autor"}


Aos meu pais, Alphonso e Olga Dedico 


\section{AGRADECIMENTOS}

Ao Prof. Dr. Sérgio Batista Alves, pela orientação, amizade, compreensão e oportunidade de realizar o Curso de Pós-graduação em Entomologia nesta Escola. Ao Prof. Dr. José Djair Vendramim por ceder espaço para a criação dos insetos.

A Coordenação de Aperfeiçoamento de Pessoal de Nível Superior (CAPES), pela concessão da bolsa de estudos.

A minha família que sempre me apoiou.

Aos Professores do Programa de Pós-graduação em Entomologia da ESALQ/USP, pelos ensinamentos.

Ao Professor Manoel Victor Franco Lemos e Professora Janete Apparecida Desidério Sena e orientados do Laboratório de Genética de Bactérias da Universidade Estadual Paulista (Jaboticabal-SP), especialmente às mestrandas Maila Azol e Fernanda Randon, pela participação, dedicação e persistência na realização da caracterização molecular do material da tese.

Aos colegas Paulo César e Uemerson pelo auxílio na análise dos dados. Ao colega Samuel pelo auxílio na elaboração do Summary.

Aos amigos e colegas do Laboratório de Patologia e Controle Microbiano de Insetos e do Setor de Entomologia que participaram direta ou indiretamente da condução deste trabalho.

A Walkiria, especialmente pela paciência e companheirismo durante o período de elaboração da tese.

Aos funcionários do Setor de Entomologia da ESALQ/USP, pelos auxílios prestados. 


\section{SUMÁRIO}

Página

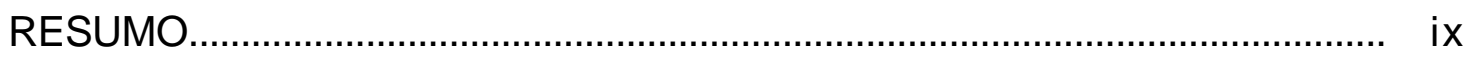

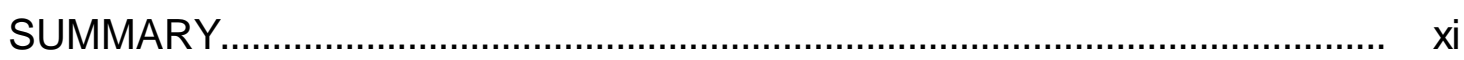

1 INTRODUÇÃO

2 REVISÃO DE LITERATURA ......................................................................

2.1 Spodoptera frugiperda (Lepidoptera: Noctuidae) (J.E. Smith, 1797) ....... 3

2.1.1 Biologia e Hábitos ................................................................................. 3

2.1.2 Prejuízos causados por Spodoptera frugiperda na cultura do milho ............................................................................................................. 4

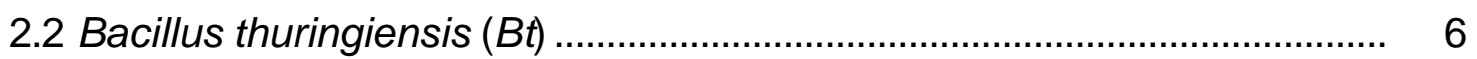

2.2.1 Presença, persistência e transmissão de Bacillus thuringiensis no ambiente ...................................................................................................... 7

2.2.2 Atividade tóxica de Bacillus thuringiensis............................................. 9

2.2.3 Nomenclatura e caracterização de Bacillus thuringiensis................... 15

2.2.4 Utilização de Bacillus thuringiensis na agricultura............................... 16

2.2.5 Impacto de Bacillus thuringiensis sobre o ambiente e organismos

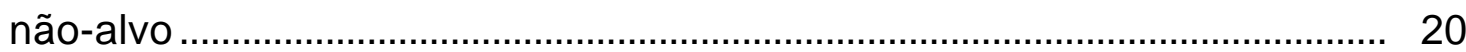

2.3 Controle de Spodoptera frugiperda........................................................ 21

2.3.1 Controle químico ................................................................................. 21

2.3.2 Controle biológico ....................................................................... 21

2.3.3 Atividade de Bacillus thuringiensis para Spodoptera frugiperda....... 24 
3 ISOLAMENTO E INFLUÊNCIA DAS CARACTERÍSTICAS QUÍMICAS DO SOLO NA OBTENÇÃO DE Bacillus thuringiensis ..................................... 27

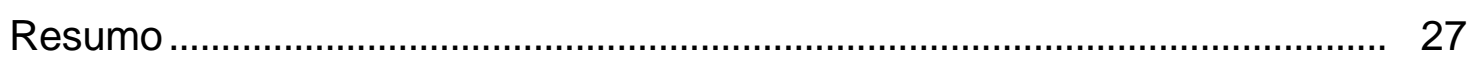

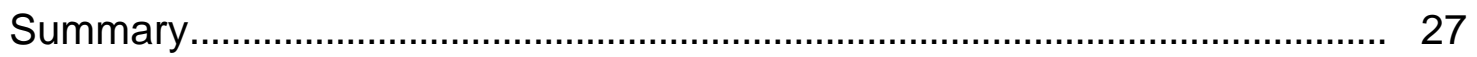

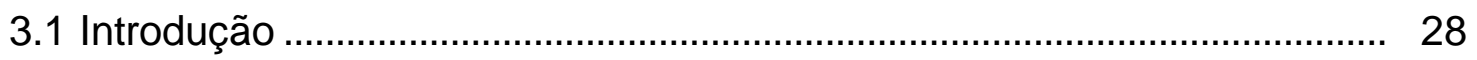

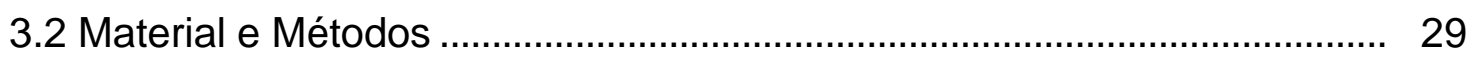

3.2.1 Isolamento de Bacillus thuringiensis a partir de amostras de solos

3.2.2 Influência das características químicas do solo na obtenção de Bacillus thuringiensis

3.3 Resultados e Discussão

3.3.1 Isolamento de Bacillus thuringiensis a partir de amostras de solos

3.3.2 Influência das características químicas do solo na obtenção de Bacillus thuringiensis

3.4 Conclusões

4 SELEÇÃO, EFEITOS SUBLETAIS DE Bacillus thuringiensis PARA Spodoptera frugiperda E CARACTERIZAÇÃO MOLECULAR DOS ISOLADOS.

Resumo 40

Summary. 41

4.1 Introdução

4.2 Material e Métodos

4.2.1 Criação dos insetos 43

4.2.2 Testes de patogenicidade 44

4.2.3 Testes de estimativa da Concentração Letal Média $\left(\mathrm{CL}_{50}\right)$............... 45

4.2.4 Efeitos subletais 45

4.2.5 Caracterização molecular dos isolados de Bacillus thuringiensis.... 46

4.3 Resultados e Discussão 49

4.3.1 Testes de patogenicidade 49 
4.3.2 Interação inseto x patógeno nas populações testadas....................... 59

4.3.3 Testes de estimativa da concentração letal média $\left(C L_{50}\right)$................. 60

4.3.4 Efeitos subletais ........................................................................... 64

4.3.5 Caracterização molecular................................................................ 70

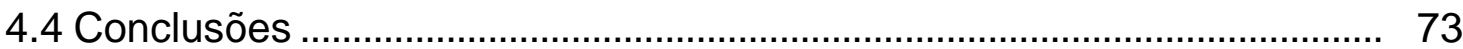

5 PERSISTÊNCIA E ATIVIDADE DE Bacillus thuringiensis PARA Spodoptera frugiperda EM CASA-DE-VEGETAÇÃO E CAMPO..................... 75

Resumo ……................................................................................... 75

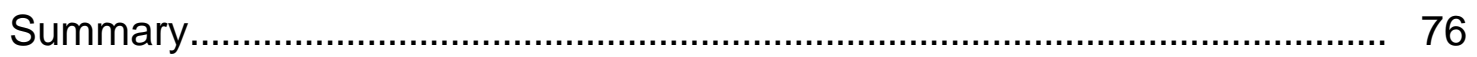

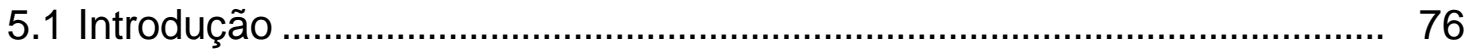

5.2 Material e Métodos .................................................................................. 77

5.2.1 Bioensaio preliminar ............................................................................ 77

5.2.2 Bioensaio em casa-de-vegetação ………………………………..... 80

5.2.3 Bioensaio em campo ………………………………………...... 82

5.3 Resultados e Discussão .................................................................. 82

5.3.1 Bioensaio preliminar .................................................................... 82

5.3.2 Bioensaios em casa-de-vegetação e campo ...................................... 87

5.4 Conclusões............................................................................................... 91

6 INTERAÇÃO DE Bacillus thuringiensis COM OUTROS ENTOMOPATÓGENOS NO CONTROLE DE Spodoptera frugiperda........... 92

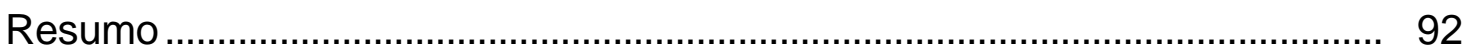

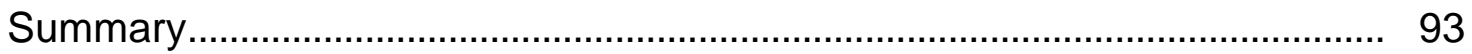

6.1 Introdução .................................................................................. 93

6.2 Material e Métodos ................................................................................... 94

6.2.1 Avaliação da interação do nematóide entomopatogênico (Heterorhabditis sp.) e Bacillus thuringiensis................................................ 94

6.2.2 Avaliação da interação entre fungos entomopatogênicos ( $B$. bassiana e N. rileyi) x Bacillus thuringiensis ................................................ 96

6.2.3 Avaliação da interação entre Virus de Poliedrose Nuclear de $S$. frugiperda (VPNSf) $\times$ Bacillus thuringiensis 
6.3 Resultados e Discussão

6.3.1 Nematóide entomopatogênico (Heterorhabditis sp.) x Bacillus thuringiensis

6.3.2 Fungos entomopatogênicos (Beauveria bassiana e Nomuraea rileyi) $\times$ Bacillus thuringiensis.

6.3.3 Virus de Poliedrose Nuclear de $S$. frugiperda (VPNSf) $\times$ Bacillus thuringiensis 105

6.4 Conclusões 107

7 CONCLUSÕES GERAIS 108 REFERÊNCIAS BIBLIOGRÁFICAS 110 


\title{
ESTUDOS DE Bacillus thuringiensis Berliner VISANDO AO CONTROLE DE Spodoptera frugiperda (J. E. Smith)
}

\author{
Autor: RICARDO ANTONIO POLANCZYK \\ Orientador: Prof. Dr. SÉRGIO BATISTA ALVES
}

\section{RESUMO}

A partir de 24 amostras de solos foram isoladas 461 colônias bacterianas, sendo que destas 190 foram identificadas como Bacillus thuringiensis $(B t)$. A relação entre as características químicas das amostras de solos e a presença do patógeno pode ser expressa por iBt $=-0,4+0,6 \mathrm{Ca}+$ $0,07 \mathrm{Cu}+0,009 \mathrm{Fe}-0,53 \mathrm{Mg}-0,12 \mathrm{Mn}+1,26 \mathrm{Zn}$. Dentre os 83 isolados de $B t$ testados para o controle de Spodoptera frugiperda, o ESALQ 3.7 mostrou-se mais promissor para o controle desta praga, causando $86,6 \%$ de mortalidade em lagartas provenientes da população de São Paulo, com uma $\mathrm{CL}_{50}$ estimada de $0,749 \times 10^{8}$ esporos $/ \mathrm{mL}$. Esse isolado possui as toxinas Cry1Ac, Cry $1 \mathrm{C} \mathrm{e}$ Cry1E que justificam sua eficiência para $S$. frugiperda. Toxinas da classe Cry1 foram encontradas em $72 \%$ dos isolados testados contra este inseto. Foram observadas diferenças na suscetibilidade entre as três populações (São Paulo, Minas Gerais e Rio Grande do Sul) da lagarta-do-cartucho do milho para 49,4\% dos isolados testados e na população de São Paulo, alguns isolados afetaram os parâmetros biológicos das lagartas sobreviventes aos tratamentos. A persistência do Dipel foi superior às outras formulações de $B t$, até 27 horas 
depois da aplicação dos tratamentos (65.772 esporos $/ \mathrm{mL}$ ), porém sua meia vida ( $\pi=17,54$ horas) foi inferior ao Ecotech e Bac-Control. O estudo da persistência do isolado ESALQ 3.7 foi prejudicado por fatores bióticos e abióticos tanto em campo como em casa-de-vegetação, que comprometeram a validação dos resultados. Não foi verificada diferença estatística significativa nas notas da escala de dano causado pela lagarta-do-cartucho na testemunha e o tratamento com o isolado ESALQ 3.7. Nos estudos de interação com outros entomopatógenos observou-se que entre Bt e Heterorhabditis sp. ocorreu interação positiva, variando de efeito aditivo a sinergismo subaditivo, de acordo com a concentração do nematóide. Entre $B t$ e os fungos entomopatogênicos Beauveria bassiana e Nomuraea rileyi foi verificada interação negativa (antagonismo) e entre um vírus de poliedrose nuclear e Bt a interação foi negativa e positiva (efeito aditivo), dependendo da concentração do vírus. 


\title{
Bacillus thuringiensis Berliner RESEARCH APPLIED FOR THE CONTROL OF Spodoptera frugiperda (J. E. Smith)
}

\author{
Author: RICARDO ANTONIO POLANCZYK \\ Adviser: Prof. Dr. SÉRGIO BATISTA ALVES
}

\section{SUMMARY}

From 24 soil samples about 461 bacterial colonies have been isolated, and 190 were identified as Bacillus thuringiensis $(B t)$. The relation between soil chemical characteristics and the presence of this pathogen may be expressed by the equation $\mathrm{i} B t=-0,4+0,6 \mathrm{Ca}+0,07 \mathrm{Cu}+0,009 \mathrm{Fe}-0,53 \mathrm{Mg}-0,12 \mathrm{Mn}+$ $1,26 \mathrm{Zn}$. Among $83 \mathrm{Bt}$ isolates assayed against Spodoptera frugiperda, the ESALQ 3.7 was the most effective to control this pest, causing $86.6 \%$ of mortality to São Paulo larvae, with an estimated LC $_{50}$ of $0.749 \times 10^{8}$ spores $/ \mathrm{mL}$. This isolate has the toxins Cry $1 \mathrm{Ac}$, Cry $1 \mathrm{C}$ e Cry $1 \mathrm{E}$ that justify its efficiency against $S$. frugiperda. The Cry 1 toxins were found in $72 \%$ of isolates assayed for this pest. There have been observed differences in the susceptibility among three fall armyworm populations (São Paulo, Minas Gerais e Rio Grande do Sul) to $49.4 \%$ of the assayed isolates, and some of them affected the biological parameters of the São Paulo larvae. The Dipel persistence was higher than the others $B t$ based products, until 27 hours after application (65.772 spores $/ \mathrm{mL}$ ), but its half life ( $\pi=17.54$ hours) was lower than Ecothech and Bac-Control. The study of ESALQ 3.7 persistence was prejudiced by biotic and abiotic factors in 
field condition and at the greenhouse conditions, that consequently constrained the data validation. About the isolate ESALQ 3.7 efficiency in the field, there was no statistical differences in the damage caused by fall armyworm in the control and treatment. In the interaction studies with other entomopathogens, it was observed a positive interaction between $B t$ and Heterorhabditis sp. This interaction varied from na additive effect to a subadditive sinergism, according to nematode concentration. Between Bt and entomopathogenic fungi Beauveria bassiana e Nomuraea rileyi it was observed a negative interaction (antagonism). Also, the interaction between a poliedrosis nuclear vírus and $B t$ varied according to the virus concentration. 


\section{INTRODUÇÃO}

O aumento da produção agrícola brasileira para atender à crescente demanda por alimentos, exportação de grãos e seus subprodutos têm impactos diretos sobre o agroecossistema, pois está ligado ao uso intenso de insumos visando diminuir as perdas, causadas por fatores bióticos e abióticos, durante 0 processo produtivo. Os agrotóxicos, embora de grande importância no controle de pragas, são freqüentemente, utilizados em grandes quantidades, sem orientação técnica, causando uma série de problemas ao ambiente e aos agricultores.

Entre as culturas de grande importância para o Brasil, o milho destaca-se na alimentação humana e animal, como matéria-prima para a indústria e exportação, contribuindo com a economia nacional e o desenvolvimento social no campo. A produção brasileira em 2003 deve atingir 47,4 milhões de toneladas contra 35,4 milhões de toneladas em 2002 (IBGE, 2004). Para alcançar um rendimento satisfatório o agricultor deve dar atenção aos vários fatores que afetam a produção, destacando-se os insetos-praga, especialmente a lagarta-do-cartucho (Spodoptera frugiperda).

$\mathrm{O}$ ataque dessa praga, dependendo das condições climáticas e estágio de desenvolvimento da cultura, pode afetar, significativamente, a produção. O controle químico, principal medida empregada para evitar que os prejuízos atinjam o nível de dano econômico, muitas vezes não tem a eficácia desejada e apresenta alto custo, pois geralmente são necessárias várias aplicações. Esse tipo de controle pode, também, contaminar os grãos deixando resíduos nos alimentos causando problemas de saúde pública. Os agrotóxicos 
utilizados no controle de pragas do milho podem prejudicar a entomofauna benéfica, impedindo que o controle biológico natural atue, favorecendo 0 surgimento de novas pragas ou ressurgência de outras. Devido a estes fatores, a busca por alternativas que possam minimizar ou até mesmo substituir os inseticidas convencionais foi intensificada e, atualmente, as novas táticas abrangem uma série de alternativas: plantas resistentes, inseticidas seletivos, parasitóides e microrganismos entomopatogênicos. Entre os entomopatógenos, o Bacillus thuringiensis (Bt) Berliner, 1915 destaca-se pela sua ampla utilização no combate dos insetos praga, especialmente lepidópteros.

Apesar do uso deste patógeno para o controle da lagarta-do-cartucho ter sido considerado em estudos iniciais pouco eficiente, o crescente interesse dos pesquisadores por medidas de controle que estejam de acordo com os objetivos do Manejo Integrado de Pragas (MIP), levou à obtenção de resultados promissores. Muitos estudos ainda são necessários para estabelecer um conjunto de medidas eficazes, que possam servir de base para o MIP desta praga, mas o Bt mostra-se como uma excelente alternativa que precisa ser mais bem explorada, tanto em termos de pesquisa básica como aplicada.

Esta pesquisa foi conduzida com o objetivo de isolar e selecionar, em laboratório, isolados de $B t$ eficientes para diferentes populações de $S$. frugiperda, testando posteriormente sua eficácia em semicampo e campo, bem como explorar alguns aspectos importantes da relação patógeno x praga: efeitos subletais, identificação das toxinas mais eficientes, diferenças na suscetibilidade entre populações geograficamente diferentes e interação com outros entomopatógenos. 


\section{REVISÃO DE LITERATURA}

\subsection{Spodoptera frugiperda (Lepidoptera: Noctuidae) (J.E. Smith, 1797)}

\subsubsection{Biologia e Hábitos}

A lagarta-do-cartucho, Spodoptera frugiperda (J. E. Smith, 1797) (Lepidoptera: Noctuidae) foi reconhecida pela primeira vez em 1797, na Geórgia (EUA) e inicialmente foi classificada como Phalaena frugiperda, passando por várias denominações até receber o nome atual de Spodoptera frugiperda. Este inseto possui ampla distribuição geográfica, ocorrendo desde a região central dos EUA até a Argentina e em algumas ilhas a oeste da Índia (Bertels, 1970; Pedigo, 1989). É também conhecida como lagarta militar e lagarta do milharal.

S. frugiperda é um inseto de metamorfose completa e os adultos, de hábito noturno, acasalam-se três dias após a emergência. As fêmeas, principalmente nos primeiros quatro dias após a cópula, podem colocar até 1000 a 2000 ovos, em camadas e recobertos por filamentos brancos, escamas e pêlos (Ferraz, 1982; Leiderman \& Sauer, 1953; Valicente \& Cruz, 1991).

As lagartas eclodem entre dois e três dias após a colocação dos ovos (Ferraz, 1982). Sua coloração varia de pardo-escura até quase preta, apresentando três finas linhas longitudinais branca-amareladas na parte dorsal do corpo. Podem migrar para plantas vizinhas à procura de folhas menos danificadas ou mais tenras. Devido, principalmente, ao canibalismo que se manifesta a partir do terceiro ínstar, é raro encontrar mais de duas lagartas na mesma planta (Ávila et al., 1997; Bianco, 1991; Brett \& Bastida, 1963; Cruz, 
1995; Gassen, 1994; Leiderman \& Sauer, 1953). Durante a fase larval o inseto pode apresentar de quatro a sete ínstares, variando conforme a fonte de alimento (artificial ou natural), temperatura, sexo e genética. A duração desta fase é de 12 a 30 dias, quando a lagarta atinge aproximadamente $5 \mathrm{~cm}$ de comprimento (Lordello et al., 1980; Lucchini, 1977; Nalim, 1991; Parra \& Haddad, 1989).

Ao completar o desenvolvimento a lagarta penetra no solo, onde se transforma em crisálida. Em campo, a fase de crisálida dura em média 11 dias (Valicente \& Cruz, 1991). Em laboratório a duração desta fase varia entre 8 e 11 dias (Leiderman \& Sauer, 1953; Melo \& Silva, 1987; Silveira et al., 1997).

Os adultos emergem a noite e apresentam acentuado dimorfismo sexual, medindo cerca de $3,5 \mathrm{~cm}$ de envergadura, com as asas anteriores pardo escuras e as posteriores branco-acinzentadas (Cruz, 1995; Ferraz, 1982).

\subsubsection{Prejuízos causados por Spodoptera frugiperda na cultura do milho}

A lagarta-do-cartucho é de difícil controle devido à sua ampla gama de hospedeiros e sua grande capacidade de dispersão durante o período de cultivo. O movimento migratório rápido e de longo alcance serve como mecanismo de escape para determinados patógenos, cuja eficácia depende da densidade do hospedeiro (Knipling, 1980).

A lagarta-do-cartucho ataca algodão, alfafa, amendoim, arroz, aveia, batata, batata doce, cana-de-açúcar, hortaliças, milho, soja e trigo, sendo mais comum em gramíneas. Neste sentido, Pashley (1988) listou 80 espécies de plantas hospedeiras, distribuídas em 23 famílias. No Brasil, já na década de 20 foi relatada a presença dessa praga em vários Estados, causando severos danos em algumas culturas (Leiderman \& Sauer, 1953). Segundo Cruz et al. (1999), as perdas causadas pela lagarta-do-cartucho no Brasil atingem cerca de U\$ 40 milhões por ano. 
No milho, a referida praga causa perda de $20 \%$ na produção de grãos, quando o desfolhamento ocorre próximo à floração (Carvalho, 1970; Cruz, 1980). Gassen (1994) enfatiza que os maiores danos ocorrem na fase em que a planta apresenta de oito a 10 folhas, podendo ocorrer uma redução de $19 \%$ no rendimento de grãos. Na fase de até seis e a partir de 12 folhas, os danos são inferiores a $9 \%$ na produção de grãos. Sua presença evidencia-se por folhas danificadas, com dejetos no centro da planta. Silva et al. (1983) ressaltam que pode ocorrer a destruição completa das plantas em caso de infestação intensa, em condições de estresse hídrico.

As lagartas recém-eclodidas atacam o parênquima foliar de uma das faces da folha, deixando apenas a epiderme membranosa, o que confere um aspecto transparente à folha e em ínstares mais adiantados, os insetos passam a perfurá-las. Quando o ataque ocorre nos estágios iniciais da cultura, pode causar a morte de plantas, reduzindo o "stand". Pode também se dirigir para a região da espiga, atacando o pedúnculo e impedindo a formação de grãos. Pode ainda penetrar nas espigas na sua porção basal e danificar diretamente os grãos ou alimentar-se da ponta da espiga. O dano mais severo é causado por lagartas de quinto e sexto ínstares (Bianco, 1991; Carvalho, 1982; Cruz, 1980; Cruz \& Turpin, 1982; Valicente \& Cruz, 1991; Waquil et al., 1982) (Figura 1).
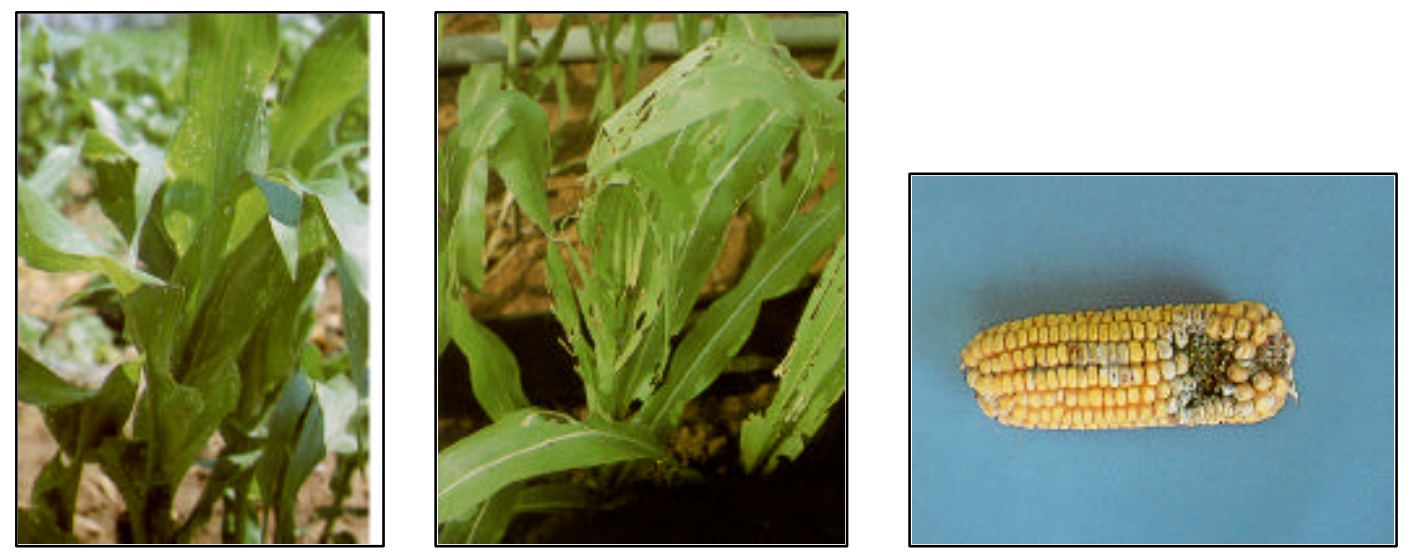

Figura 1 - Danos causados por Spodoptera frugiperda em milho. A) folhas raspadas; B) folhas perfuradas; $C$ ) espiga danificada (Cruz et al. 1997) 


\subsection{Bacillus thuringiensis (Bt)}

A microflora bacteriana dos insetos, confinada no intestino, é rica, diversa e compreende bactérias Gram positivas e negativas. Muitas delas auxiliam na digestão dos alimentos, porém algumas são patogênicas e recebem grande atenção dos pesquisadores devido ao seu magnífico potencial para o controle de pragas agrícolas e urbanas (Priest, 2000). Entre estes patógenos destaca-se Bacillus thuringiensis (Bt) (Bacillaceae), bactéria em forma de bastonete, formadora de esporos e capaz de produzir inclusões cristalinas durante a esporulação, que são responsáveis pela atividade tóxica desta espécie (Glare \& O'Callagham, 2000) (Figura 2).

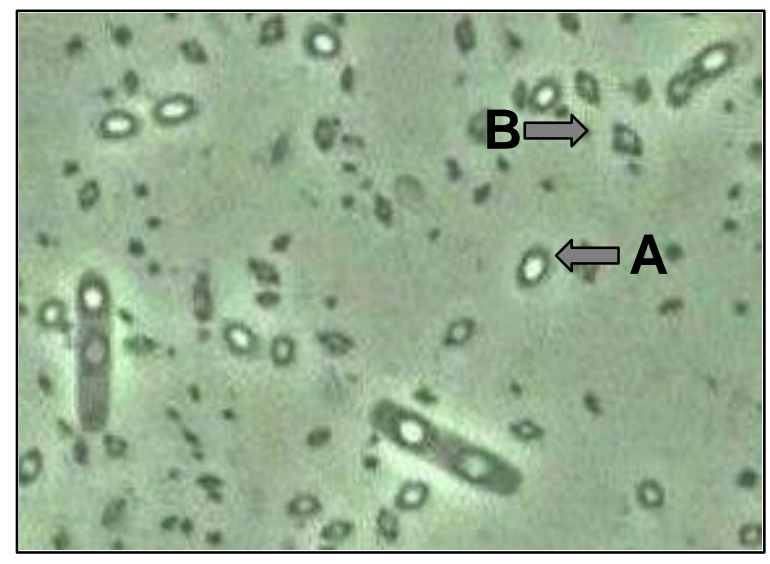

Figura 2 - Células de Bacillus thuringiensis mostrando o esporo (A), de coloração mais clara; e o cristal bipiramidal (B), de coloração mais escura. Fonte: helios.bto.ed.ac.uk/ bto/microbes/bt.htm

O $B t$ foi pela primeira vez descrito por Berliner em 1911 quando este pesquisador isolou o bacilo de Anagasta kuehniella. Posteriormente, ele o nomeou $B$. thuringiensis em homenagem à província de Thuringia (Alemanha), onde o primeiro inseto infectado foi encontrado. Embora esta seja a primeira descrição utilizando o nome de Bacillus thuringiensis, não foi o primeiro isolamento deste patógeno. Em 1901, o biólogo S. Ishiwata isolou a bactéria que 
era o agente causal da "sotto-disease". Em 1908, Iwabuchi a denominou como $B$. sotto Ishiwata, que posteriormente foi considerado nome inválido e o nome mais recente (Bacillus thuringiensis) foi mantido (Glare \& O'Callagham, 2000).

Embora geralmente o termo Bacillus thuringiensis seja empregado para uma única espécie, na verdade ele pertence a um complexo de várias espécies (B. anthracis, $B$. cereus, $B$. mycoides, $B t$ e $B$. weihenstephanensis) denominado $B$. cereus. Bt e $B$. cereus, por exemplo, mostram características fenotípicas e bioquímicas comuns, mas por definição, Bt pode ser diferenciado pela presença dos cristais (Luthy \& Wolfersberger, 2000), visíveis em microscopia de contraste de fase, embora este seja um critério com pouco valor taxonômico (Lysenko, 1983). Os métodos moleculares como hibridização do DNA cromossômico, análise de ácidos graxos e fosfolipídeos, comparação da seqüência 16S rRNA, entre outros, mostram que estas duas espécies são, na verdade, somente uma. Esta semelhança é devida à transferência de plasmídeos que codificam as $\delta$-endotoxinas de $B t$ para $B$. cereus e, por outro lado, o Bt pode perder a capacidade de produzir estas toxinas, "tornando-se" $B$. cereus". Portanto, a distinção entre estas espécies não é clara e continua sendo assunto de interesse de muitos taxonomistas (Glare \& O'Callagham, 2000; Hansen \& Salamitou,2000; Schnepf et al., 1998).

\subsubsection{Presença, persistência e transmissão de Bacillus thuringiensis no ambiente}

O Bt ocorre em diversos ambientes e é facilmente isolado a partir de diferentes substratos por métodos relativamente simples e eficientes (Glare \& O'Callagham, 2000). O número de células de $B t$ obtidas varia entre $10^{2}$ e $10^{4}$ unidades formadoras de colônias (UFC) por grama de solo, enquanto que em plantas este número varia entre 0 e 100 UFC cm$~^{-2}$ (Damgaard, 2000).

Esse microrganismo não é considerado um entomopatógeno com grande agressividade e nem sempre esporula em insetos antes ou após sua 
morte. Por esse motivo, este entomopatógeno dificilmente é encontrado causando epizootias naturais em insetos, porém alguns trabalhos (Brownbridge \& Onyango, 1992; Burges \& Hurst, 1977; Meadows et al, 1992; Porcar \& Caballero, 2002; Rajagopal et al., 1988; Talalaev, 1956; Vankova \& Purrini, 1979) relatam este fato, especialmente em lepidópteros, inclusive em local onde o Bt nunca foi aplicado. De acordo com Damgaard (2000), estas epizootias ocorrem sob certas condições específicas em campo, em criações de insetos e em ambientes onde são armazenados grãos. Baseado nestas e em outras observações Hansen \& Salamitou (2000) sugerem que essa bactéria, embora apresente uma capacidade de multiplicação limitada, pode ocasionalmente tornar-se epizoótica em escala limitada.

Este patógeno pode se multiplicar em microhabitats favoráveis como, por exemplo, os insetos-alvo, embora possa crescer e esporular em solos ricos em nutrientes. No entanto, devido à sua baixa ocorrência epizoótica, é pouco provável que a principal fonte de toxinas e esporos sejam os insetos colonizados. Também existe a hipótese que esse patógeno tenha algum tipo de relação simbiótica, talvez com as plantas, para explicar a produção de toxinas tão específicas e eficientes (Aronson \& Shai, 2001).

As informações sobre o destino das toxinas de $B t$ no solo são limitadas e estimativas da persistência de sua atividade no ambiente variam muito. Alguns trabalhos mostram que suas toxinas unem-se a ácidos húmicos, suplementos orgânicos ou com partículas de solo que as protegem da degradação por microrganismos sem, no entanto, perder sua atividade inseticida. Nas folhas, a meia-vida de esporos de Bt é muito menor que no solo (100-200 dias), variando, geralmente, de menos de um dia até três dias. Uma vez que os cristais são mais resistentes à radiação ultravioleta que os esporos, a atividade larvicida reflete a atividade dos cristais, embora o número de esporos viáveis possa ser reduzido. Existem várias teorias que tentam explicar o nicho ecológico do Bt. Diferente da maioria dos entomopatógenos, a reciclagem deste patógeno é pobre no solo, levando à hipótese de ele ser 
essencialmente um microrganismo com atividade inseticida acidental (Martin \& Travers, 1989). O fato de esta bactéria ser normalmente encontrada no ambiente, independentemente da presença ou não de insetos, dá suporte a esta teoria. Meadows (1993) sugere quatro possíveis explicações para a presença de $B t$ no solo: 1 - $B t$ raramente desenvolve-se no solo, mas é depositado neste substrato por insetos, folhas, etc, dessa forma o solo atuaria como um reservatório de esporos, que poderiam, posteriormente, ser transportados a longas distâncias pelo vento; 2- Bt pode ser patogênico a insetos de solo com reduzida importância econômica, com os quais poucos estudos foram realizados; $3-B t$ pode desenvolver-se no solo quando existem nutrientes suficientes, obtidos principalmente, de resíduos orgânicos em decomposição e, 4 - afinidade com $B$. cereus, com o qual Bt pode trocar material genético, possibilitando sua permanência no ambiente.

\subsubsection{Atividade tóxica de Bacillus thuringiensis}

O Bt desenvolve-se, em condições aeróbicas, em meios artificiais bastante simples. Sob certas restrições, como ausência de nutrientes ou acúmulo de metabólitos indesejáveis, esta bactéria entra em processo de esporulação durante a fase estacionária. No início da esporulação Bt sintetiza uma grande quantidade de proteínas com atividade inseticida. As proteínas acumuladas formam um corpo de inclusão cristalina, razão pela quais elas são denominadas Cry (Yamamoto \& Dean, 2000). Estas toxinas são codificadas por genes cry e sua toxicidade está ligada à região $\mathrm{N}$-terminal das cadeias polipeptidicas, enquanto que a porção C-terminal determina a forma da estrutura do cristal (Li et al., 1991).

Os genes cry podem estar localizados tanto no cromossomo como em grandes plasmídeos (40-200 MDa) ou em ambos (Gonzáles et al., 1982; Sanchis et al., 1998). Sua expressão é regulada por dois mecanismos: o 
primeiro é dependente de fatores sigma específicos da fase de esporulação, onde está baseada a classificação da maioria dos genes cry, e outro independente do processo de esporulação, como o gene vip3, cujos fatores são típicos da fase de crescimento vegetativo (Valadares-Inglis et al., 1998). Algumas cepas de Bt apresentam um único gene codificador (Bt kurstaki HD73), enquanto outras apresentam genes diferentes, porém relacionados ( $B t$ aizawai 7.29) (Lereclus et al., 1993; Sanchis et al., 1998).

A inclusão cristalina pode ser responsável por mais de $25 \%$ do peso seco das células. A quantidade de toxina produzida em laboratório (aproximadamente $0,5 \mathrm{mg}$ de proteína/ $\mathrm{mL}$ de meio de cultura) e o tamanho dos cristais indicam que cada célula tem que sintetizar de $10^{6}$ a $2 \times 10^{6}$ moléculas de $\delta$-endotoxina para formar o cristal (Agaisse \& Lereclus, 1995).

Após a ingestão dos esporos+cristais pelo inseto, os cristais são solubilizados em $\mathrm{pH}$ alcalino, originando as protoxinas que em presença de enzimas digestivas (proteinases) são convertidas em 4 ou mais polipeptídeos tóxicos ( $\delta$-endotoxinas). Essas toxinas hidrolizadas cruzam a membrana peritrófica, liga-se a receptores específicos localizados na membrana apical das células colunares do intestino médio, interferindo no gradiente iônico e balanço osmótico da membrana apical formando poros que aumentam a permeabilidade da membrana. O aumento na absorção de água causa lise celular e eventual ruptura e desintegração das células do intestino médio. $O$ inseto também pode morrer por inanição, uma vez que pouco tempo após a infecção o inseto cessa a alimentação (Copping \& Menn, 2000).

As proteinases, junto com as peptidases e dipetidases, formam 0 grupo das proteases que são enzimas que hidrolisam ligações peptídicas. As proteínas clivam ligações peptídicas internas em proteínas, as peptidases atacam as ligações de oligopeptídeos a partir do resíduo $\mathrm{N}$-terminal (aminopeptidases) ou C-terminal (carboxipeptidases) e as dipeptidases hidrolisam dipeptídeos (Panizzi \& Parra, 1991). 
De acordo com Knowles (1994), o intestino dos insetos suscetíveis geralmente possui um pH elevado, o que evita a germinação dos esporos ingeridos do patógeno. Porém as $\delta$-endotoxinas causam a paralisia do intestino, retendo os esporos e destruindo a parede do intestino. O conteúdo do intestino mistura-se ao da hemolinfa, reduzindo o $\mathrm{pH}$ e fornecendo nutrientes para iniciar a germinação dos esporos. O inseto morto serve então como fonte de alimento para o crescimento vegetativo da bactéria. Copping \& Menn (2000) ressaltam que diferentes toxinas ligam-se a diferentes receptores em diversas espécies de insetos e com intensidade variada, o que explica a especificidade destas toxinas. Devido à importância do esporo na patogenicidade desta bactéria, a maioria dos produtos comercializados possui os esporos e as toxinas, visando aumentar sua atividade tóxica.

Knowles (1994) descreve as etapas da patologia de Bt sobre insetos: aumento da absorção de glicose e início dos sintomas histopatológicos (1-5 minutos); paralisia do intestino médio, cessa a alimentação, membrana apical permeável a corantes, aumento do volume e formação de vesículas nas células, aumento do $\mathrm{pH}$ da hemolinfa e redução do $\mathrm{pH}$ do lúmen (5-10 minutos); aumento do fluxo e concentração de $\mathrm{K}^{+}$da hemolinfa, diminuição do transporte de glicose e leucina para a hemolinfa, colapso metabólico celular (10-30 minutos); lise celular e ruptura da membrana basal, paralisia geral ocorre em 1 a 7 horas; morte por falta de alimento ou septicemia (1-3 dias).

Uma determinada cepa de $B t$ pode produzir um ou mais cristais e estes, por sua vez, podem conter uma ou mais toxinas com peso molecular variado. Por exemplo, Bt kurstaki HD-1 contém três Cry1 (130 kDa) e duas Cry2 (70 kDa), enquanto que $B t$ tenebrionis produz uma única toxina com peso molecular de $67 \mathrm{KDa}$. A forma do cristal é determinada pelo número de $\delta$ endotoxinas presentes, e uma relação parcial entre composição da proteína e sua estrutura molecular foi estabelecida por Glare \& O'Callagham (2000) e Lereclus, et al. (1993). 
As estruturas terciárias de 3 toxinas (Cry1 Aa, Cry3Aa e Cry2Aa) foram determinadas por cristalografia de raio X. Assim verificou-se a presença de 3 diferentes regiões estruturais, cada uma com cerca de 200 resíduos de aminoácidos. A "região 1" é responsável pela inserção da toxina na membrana, a "região 2" contém os receptores responsáveis pela ligação toxina-membrana e a "região 3" protege a molécula da digestão por proteinases e também tem papel de receptor (Schnepf et al., 1998; Yamamoto \& Dean, 2000) (Figura 3).

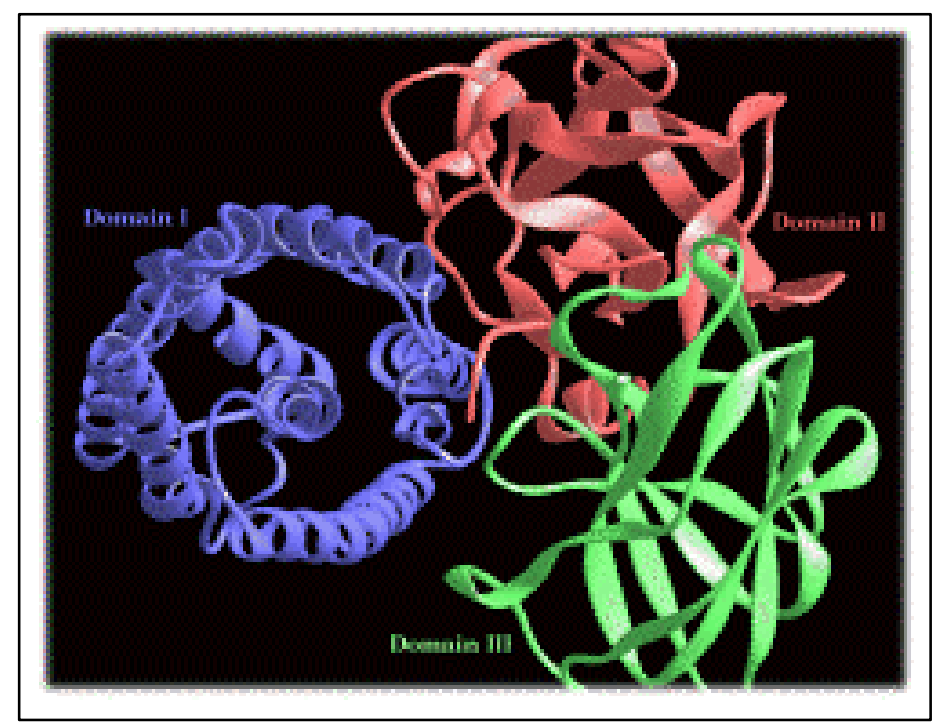

Figura 3 - Estrutura molecular da toxina de Bacillus thuringiensis mostrando as três regiões funcionais ("domains"). Fonte: www.iia.msu.edu/ absp/toxin.gif

A ligação ao receptor é um processo que ocorre em duas etapas, envolvendo processos reversíveis e irreversíveis. No primeiro caso, a toxina em questão (Cry1Ab) não possui a "região 1", e apesar da toxina se ligar ao receptor, esta ligação é insuficiente para conferir ação tóxica contra o inseto. $O$ segundo caso envolve uma ligação forte da toxina com o receptor e a inserção 
da toxina na membrana apical, com o conseqüente desenvolvimento da doença no inseto (Schnepf et al., 1998).

Várias cepas de $B t$ também produzem outras endotoxinas, de menor peso molecular (25-28 kDa), denominadas de endotoxinas citolíticas (Cyt). Diferente das $\delta$-endotoxinas, as Cyt possuem um maior espectro de ação contra insetos, tanto in vivo como in vitro. Os genes que codificam estas toxinas estão contidos em plasmídeos grandes com $125 \mathrm{~kb}$, que também contêm genes que codificam as toxinas Cry (Glare \& O'Callagham, 2000).

Além das toxinas do cristal, essa bactéria pode produzir outras toxinas, como a $\beta$-exotoxina, também denominada thuringiensina. Essa toxina é termoestável, sendo produzida por várias cepas deste patógeno e possui atividade inseticida contra uma ampla gama de insetos, porém devido à sua toxicidade para vertebrados, a maioria dos bioinseticidas à base de $B t$ utiliza subespécies ou isolados que não produzem a $\beta$-exotoxina. $B t$ também produz muitas exoenzimas que são patogênicas para insetos. Estas toxinas podem destruir a membrana peritrófica do inseto, danificando o epitélio intestinal. Recentemente, foi descoberta uma nova classe de toxinas, as VIPs ou proteínas vegetativas, com elevada toxicidade para lepidópteros, incluindo Agrotis ipsilon, Heliothis virescens, Helicoverpa zea, Spodoptera exigua e S. frugiperda (Glare \& O'Callagham, 2000). As referidas toxinas causam paralisia do intestino e lise das células do epitélio do intestino médio, de modo semelhante às proteínas Cry (Yu et al., 1997). De acordo com Rice (1999), análises do DNA feitas por PCR mostram que o gene que codifica a toxina VIP3A é encontrado em cerca de $30 \%$ dos isolados de $B t$.

Embora os produtos comerciais disponíveis restrinjam-se ao controle de lepidópteros, dípteros e coleópteros, Glare \& O'Callagham (2000) citam que mais de 1.000 espécies de insetos, pertencentes a diversas ordens de insetos, são suscetíveis a este patógeno (Tabela 1). A suscetibilidade de insetos a esse patógeno pode variar de acordo com a origem geográfica da população da praga. Neste sentido, López-Edwards et al. (1999) estimaram diferentes $\mathrm{CL}_{50}$ de 
um mesmo isolado de Bt para diferentes populações de $S$. frugiperda, coletadas em 5 regiões do México.

Além da patogenicidade e virulência desse patógeno contra insetospraga, outros aspectos como os efeitos subletais sobre os indivíduos sobreviventes, embora difíceis de detectar, certamente ocorrem e representam um importante parâmetro, que auxilia na avaliação de sua atividade tóxica. Também é pouco estudada a interação com outros entomopatógenos, pois além de incrementar a eficácia desta tática de controle biológico, também fornece indícios sobre o impacto ambiental de $B t$. Embora existam muitos estudos sobre as interações entre parasitóides, predadores e patógenos, poucos são aqueles que tratam da interação entre patógenos, principalmente quando envolvem espécies-praga de difícil controle.

Tabela 1. Espécies de insetos suscetíveis a Bacillus thuringiensis (Glare \& O’Callagham, 2000)

\begin{tabular}{cc}
\hline Ordem & Número de espécies \\
\hline Diptera & 266 \\
Hemiptera & 48 \\
Hymenoptera & 62 \\
Isoptera & 5 \\
Coleoptera & 106 \\
Lepidoptera & 572 \\
Neuroptera & 4 \\
Orthoptera & 6 \\
Siphonaptera & 7 \\
Thysanoptera & 3 \\
TOTAL & 1.079 \\
\hline
\end{tabular}




\subsubsection{Nomenclatura e caracterização de Bacillus thuringiensis}

No final da década de 80 , Hofte \& Whiteley (1989) propuseram uma classificação para as toxinas de $B t$, baseada na combinação de suas seqüências de aminoácidos e espectro inseticida. Nesta classificação 38 toxinas foram agrupadas em 14 classes diferentes. As quatro principais classes continham toxinas com atividade contra Lepidoptera (I), Lepidoptera e Diptera (II), Coleoptera (III) e Diptera (IV). No entanto, esse esquema apresentou problemas, pois tentou relacionar toxinas com seqüências de aminoácidos similares, com diferentes atividades inseticidas. Durante a década de 90 uma nova classificação foi proposta por Crickmore et al. (1998), baseada somente nas relações entre as seqüências de aminoácidos. Esta mudança permitiu uma alta relação entre as toxinas e eliminou a necessidade de bioensaios contra um grande um número de insetos. Até o momento mais de 250 genes cry foram seqüenciados (http://www.biols.susx.ac.uk/home/Neil_Crickmore/Bt/) e agrupados em 40 grupos de toxinas Cry.

A sorotipagem é o método mais comumente utilizado para diferenciar grupos de $B t$, mas a determinação do sorotipo nem sempre traduz a atividade inseticida de um isolado. Atualmente, 82 sorotipos são conhecidos, porém existem alguns problemas de reação cruzada com alguns isolados de $B$. cereus, cepas autoaglutinantes e também algumas cepas de $B t$ que, por não produzirem cristais, são consideradas como B. cereus (Lecadet et al., 1999).

A caracterização bioquímica é difícil, principalmente porque $B t$ mostra variações nas respostas e por este tipo de caracterização não estar sempre associada a resultados de sorotipagem. Os meios seletivos também têm sido desenvolvidos para $\mathrm{o}$ isolamento de $B t$ a partir de diferentes substratos. Entretanto, estes somente são capazes de separar Bacillus spp. e sua utilização não implica na obtenção de um número maior de isolados do que aquele obtido com métodos mais simples. 
Os avanços recentes na biologia molecular permitiram 0 desenvolvimento de métodos baseados no DNA, capazes de diferenciação inter e intraespecífica de $B t$. Tais métodos podem diferenciar cepas e isolados e podem também ser empregados para determinar a presença/ausência de determinados genes cry.

Descrita na década de 80 (Mullis \& Faloona, 1987), a técnica da Reação em Cadeia de Polimerase (PCR) permite obter in vitro várias cópias de um determinado segmento de DNA, obedecendo às seguintes etapas: a) extração do DNA que contém a região a ser amplificada, b) escolha do segmento a ser amplificado e obtenção de "primers" (iniciadores) específicos para o reconhecimento desse segmento, c) amplificação que dará origem a várias cópias, fazendo-se uso de um termociclador e, por fim, d) leitura do produto amplificado após eletroforese e coloração.

Para $B t$, esta técnica tem muitas utilidades e pode ser empregada com a finalidade de amplificar regiões conhecidas do DNA, para comparar geneticamente isolados de Bt pouco conhecidos, além de indicar o potencial inseticida de uma determinada toxina (Bravo et al., 1998; Carozzi et al., 1991; Porcar \& Juárez-Pérez, 2003).

\subsubsection{Utilização de Bacillus thuringiensis na agricultura}

A eficácia e especificidade das cepas de Bt e suas toxinas no controle de insetos praga, favoreceu a formulação de biopesticidas à base deste patógeno e, desde o primeiro produto lançado na França em 1938, mais de 100 formulações foram colocados no mercado mundial, sendo atualmente responsáveis por mais de $90 \%$ do faturamento com bioinseticidas. O continente americano é responsável por $50 \%$ deste mercado, principalmente os Estados Unidos e Canadá e a América Latina representa apenas 8 a $10 \%$ do total (Tamez-Guerra et al., 2001). Hansen \& Salamitou (2000) estimaram que a aplicação mundial anual de Bté de 13.000 toneladas. 
O produto à base de $B t$ com maior alcance no mercado mundial é o Dipel (Bt kurstaki HD-1). Este produto, pouco tóxico para ácaros, coleópteros, dípteros e hemípteros é altamente eficiente para 170 lepidópteros-praga (Beegle \& Yamamoto, 1992; Glare \& O'Callagham, 2000).

Além de o Bt ser à base da formulação dos bioinseticidas com maior sucesso comercial no mundo, marca o início da substituição dos inseticidas convencionais em várias áreas. Na década de 80 , o surgimento de novas técnicas, especialmente aquelas voltadas para a tecnologia do DNA recombinante, e manifestações públicas a respeito do uso abusivo dos inseticidas convencionais, levaram a um aumento cada vez mais crescente do interesse dos órgãos de pesquisa e indústrias sobre a utilização do Bt na agricultura e saúde pública (van Frankenhuyzen, 1993).

A liderança destes biopesticidas no mercado há mais de 40 anos, gerou um acúmulo grande de informações sobre aspectos determinantes na eficiência destes produtos: idade larval mais suscetível, comportamento alimentar do inseto, limitações ambientais, segurança, método de aplicação e formulação (Navon, 2000a).

No entanto, nem sempre os resultados obtidos no laboratório correspondem aos de campo. O comportamento alimentar do inseto, distribuição espacial/temporal dos insetos benéficos e outros fatores que influenciam a intensidade do contato entre $B t$ e organismos não-alvo podem reduzir o impacto destes biopesticidas sobre o inseto alvo (Glare \& O'Callagham, 2000).

$\mathrm{Na}$ América do Norte, produtos à base de Bt são muito utilizados para o controle de pragas florestais, principalmente: Lymantria dispar, Choristoneura fumiferana e C. occidentalis. Nos EUA, de 1980 até 1995, cerca de 2 milhões de hectares de florestas foram tratados com Bt kurstaki para o controle de $L$. dispar, em alguns casos resultando na erradicação da praga; porém este inseto ainda é o principal alvo de aplicações de Bt em florestas. A partir da década de 90, a aplicação contra $C$. fumiferana nos EUA e Canadá praticamente cessou, devido ao sucesso obtido na década anterior. Na Austrália produtos formulados 
com Bt são utilizados para controle de pragas em algodão, frutíferas, ornamentais, fumo, entre outras culturas (Glare \& O'Callagham, 2000; van Frankenhuyzen, 2000).

$\mathrm{Na}$ América Latina, Cuba e México lideram a utilização dos bioinseticidas à base de $B t$, especialmente para o controle de pragas nas culturas do algodão, banana, batata, citros, hortaliças, fumo, milho, pastagens. Esses são os únicos países que têm produção própria destes biopesticidas, tornando-os competitivos em relação aos produtos químicos. No Brasil utilizamse produtos à base de Bt para o controle de cerca de 30 pragas de importância agrícola, porém a área total em que esses produtos são aplicados é apenas a terça parte do México e semelhante à de Cuba, ou seja, cerca de 150.000 hectares. As principais limitações são o elevado custo, a concorrência com produtos químicos e a falta de investimentos dos setores público e privado, no desenvolvimento e formulação destes produtos.

$\mathrm{Na}$ China produtos à base de $B t$ são muito utilizados em cerca de 30 províncias do centro-sul do país, em uma área com cerca de um milhão de hectares contra pragas de grandes culturas, florestas e hortaliças. No Egito, a partir de 1990, estes biopesticidas são utilizados, principalmente, no controle de pragas do algodão. Em outros países como Israel, Indonésia, Malásia, Índia e países da África Ocidental, a utilização deste entomopatógeno no controle de pragas está em fase inicial de pesquisa e implementação (Salama \& Morris, 1993).

Gelernter \& Schab (1993) e Navon (2000b) afirmam que diversos fatores limitam a utilização dos referidos biopesticidas: o seu custo, que na maioria das vezes é superior ao dos inseticidas químicos; a baixa persistência em campo da maioria das formulações; o baixo espectro de ação, a ineficácia contra pragas de solo e endofíticas. Os autores enfatizam que estão sendo desenvolvidas pesquisas para minimizar essas desvantagens. Os trabalhos estão principalmente voltados para: identificação de novos genes cry, desenvolvimento de novas formulações, plantas expressando genes cry e 
ampliação dos conhecimentos das interações com outros entomopatógenos, predadores, parasitóides e mesmo inseticidas químicos.

Os genes cry introduzidos em Escherichia coli, B. subtilis, $B$. megaterium e Pseudomonas fluorescens ampliaram as possibilidades de utilização de $B t$ na agricultura. Processos fermentativos com pseudomonas recombinantes têm sido utilizados para produzir formulações contendo inclusões cristalinas encapsuladas por células mortas. Este tipo de formulação aumenta a persistência em campo destes biopesticidas devido à proteção contra a radiação ultravioleta (Schnepf et al., 1998). Raun \& Jackson (1966) e Tamez-Guerra et al., (2000) mostraram a eficácia das formulações encapsuladas e microencapsuladas, pois verificaram um aumento da persistência do Bt e o conseqüente incremento na mortalidade dos insetos alvo.

O aumento do espectro de ação das toxinas foi obtido por Gonzales et al. (1982), Klier et al. (1983) e Park et al. (2001), por meio de métodos de recombinação para reordenar a composição protéica do cristal. Esta técnica elimina as toxinas com baixa atividade inseticida e incorpora outras com maior potencial. Os trabalhos anteriormente mencionados, além de agrupar toxinas mais eficientes também têm o objetivo explorar o sinergismo entre as toxinas.

A partir da metade da década de 80 , foram obtidas as primeiras plantas transgênicas com a incorporação dos genes codificadores das proteínas tóxicas de Bt na cultura do fumo e em tomate (Dias, 1992). Segundo Ely (1993), mais de 50 espécies de plantas sofreram transformações deste tipo com resultados satisfatórios. Vários trabalhos demonstram a importância das plantas transgênicas, expressando genes de Bt como instrumento no manejo integrado de pragas (Koziel et al., 1993; Pilcher et al., 1997; Vaeck et al., 1987). 


\subsubsection{Impacto de Bacillus thuringiensis sobre o ambiente e organismos não-alvo}

Apesar dos produtos à base de $B t$ corresponderem a menos de $1 \%$ do mercado mundial de inseticidas, Glare \& O'Callagham (2000) salientam a importância de estudos sobre o impacto ambiental deste entomopatógeno, visando principalmente mostrar sua capacidade de substituir ou interagir com os inseticidas convencionais, minimizando os riscos ambientais. Os mesmos autores ressaltam que generalizações nestes aspectos são difíceis devido ao grande número de isolados existentes (mais de 60.000) e que cada caso deve ser analisado separadamente.

Em relação aos mamíferos, Hansen \& Salamitou (2000) ressaltam que embora tenha sido verificado algum efeito de algumas subespécies de $B t$ sobre animais em laboratório, estes resultados são variáveis. Glare \& O'Callagham (2000) afirmam que os casos de Bt causando doença em humanos são extremamente raros, apesar de sua utilização por mais de 60 anos. O mesmo pode ser observado para os inimigos naturais (parasitóides, patógenos e predadores), que raramente são afetados. Além disso, existem relatos na literatura de interação positiva entre estes entomopatógenos. Também sua reduzida persistência no ambiente, diminui ainda mais a possibilidade de efeitos prejudiciais sobre o mesmo. Hansen \& Salamitou (2000) afirmaram que os riscos em utilizar $B t$ devem ser sempre comparados aos riscos em utilizar agrotóxicos, com impacto reconhecidamente maior sobre o ambiente. Porém devido às semelhantes desta espécie com $B$. cereus, que é uma bactéria que pode contaminar alimentos consumidos por animais e humanos, deve-se estar sempre atento sobre o efeito de formulações de $B t$ sobre organismos não-alvo. 


\subsection{Controle de Spodoptera frugiperda}

O nível de controle para $S$. frugiperda foi estabelecido ao redor de $20 \%$ de plantas com folhas raspadas até 30 dias após a semeadura e 10\% com folhas raspadas entre 40 e 60 dias após a semeadura (Nakano et al., 1981; Gallo et al., 2002). O controle torna-se necessário em lavouras com potencial de rendimento superior a $5 \mathrm{t} / \mathrm{ha}$. Entre as dificuldades de controle deste inseto, destaca-se a localização da lagarta dentro do cartucho e a decisão de controle baseado no sintoma externo de folhas perfuradas, sem comprovar a presença do inseto no interior do cartucho (Gallo et al., 2002; Cooplantio, 2003).

\subsubsection{Controle químico}

Gallo et al. (2002) relataram 29 ingredientes ativos recomendados no controle químico de S. frugiperda. Em 1998 foram gastos no Brasil cerca de U\$ 60 milhões em inseticidas na cultura do milho, sendo que o controle de $S$. frugiperda é responsável por $40 \%$ deste valor (Omoto et al., 2000). Além disso, existem casos de relatos de evolução da resistência desta praga aos inseticidas utilizados (Diez-Rodrigues \& Omoto, 2001; Yu, 1992), mostrando que esta tática de controle tem sérias limitações práticas.

\subsubsection{Controle biológico}

O controle biológico é definido como a ação de inimigos naturais sobre uma população de praga, resultando numa posição geral de equilíbrio mais baixa do que prevaleceria na ausência daqueles (Gravena, 1992). O controle microbiano é um ramo do controle biológico que objetiva principalmente a redução ou manutenção da população de pragas em nível inferior de dano 
econômico, dentro do contexto do manejo integrado de pragas (Alves, 1998a; Gallo et al., 2002).

Como alternativa ao emprego de inseticidas químicos, existe um grande complexo de inimigos naturais com potencial para constituir novas táticas de controle de $S$. frugiperda que venham minimizar ou até mesmo substituir a utilização dos inseticidas convencionais (Ashley, 1979; Ferraz,1998; Gallo et al., 2002; Gardner et al., 1984).

Os baculovírus englobam o grupo de vírus mais estudados e utilizados como bioinseticida. Esse entomopatógeno têm como principal rota de infecção a ingestão de alimento contaminado, com a subseqüente liberação das partículas virais nas células epiteliais do intestino médio, causando a morte do inseto em poucos dias (Ribeiro et al., 1999). A fase larval é a mais suscetível à infecção, e o inseto pode ser contaminado por meio dos ovos, espiráculos, inimigos naturais, ou mais comumente pela via oral. $O$ aparecimento dos sintomas e a morte do inseto dependem de diversos fatores, como: idade do inseto, virulência do isolado e das condições climáticas (Valicente \& Cruz, 1991).

No Brasil, a ocorrência de um vírus de poliedrose nuclear (VPNSf) em S. frugiperda foi constatada em 1978 (Gerk et al., 1997), sendo que Cruz et al. (1997), Moscardi (1998), Valicente \& Costa (1995), Valicente \& Cruz (1991) ressaltam o potencial deste VPN para o manejo dessa praga. Além disso, esse patógeno é inócuo ao meio e favorece o desenvolvimento de populações de inimigos naturais.

O fungo Beauveria bassiana, de ampla distribuição geográfica, é mais freqüente em insetos e em amostras de solo, sendo encontrado no campo em coleópteros, lepidópteros, hemípteros, dípteros, himenópteros e ortópteros. A infecção pode ocorrer por via oral, pelo tegumento ou pelo espiráculo, sendo que 12 horas após o contato com o inseto, ocorre a germinação dos conídios. Decorridas 72 horas, o inseto pode ser totalmente colonizado, advindo à morte em função da falta de nutrientes e do acúmulo de substâncias tóxicas. As 
condições favoráveis para o desenvolvimento da doença são umidade relativa em torno de $90 \%$ e temperatura entre 23 e $28^{\circ} \mathrm{C}$. Outro fungo, Nomuraea rileyi, ocorre naturalmente sobre coleópteros, ortópteros e, principalmente lepidópteros. Este patógeno penetra no inseto via oral ou pelo tegumento, sendo que a germinação pode ocorrer em 12 horas e a invasão da hemocele em 24 horas. A colonização e morte do hospedeiro ocorrem entre 3 a 5 dias e 6 a 7 dias, respectivamente (Alves, 1998b).

Em relação à $B$. bassiana, embora no Brasil os relatos não sejam muitos (Castanheira et al., 1993), trabalhos desenvolvidos por Rodrigues Júnior \& Pratissoli (1989) e França et al., (1989) mostram o potencial deste patógeno para controlar a lagarta-do-cartucho. Além desses autores, Chonay (1988), Lecuona (1999) e Lezama et al. (1996) relataram a alta virulência deste fungo para a lagarta-do-cartucho na Guatemala, México e Argentina, respectivamente. A eficiência de $N$. rileyi no controle de $S$. frugiperda foi relatada no exterior por Gladstone (1989), Lezama et al. (1996), Lecuona (1999), sendo que no Brasil também existem vários relatos (Habib \& Patel,1990; Moscardi et al.,1992; Siloto et al., 2000; Tigano et al.,1995).

Os nematóides entomopatogênicos são organismos com grande potencial e ainda pouco explorados, destacando-se os gêneros Steinernema, Heterorhabditis e Neosteinernema. Espécies de Heterorhabditis têm como características favoráveis: capacidade de locomoção no solo à procura de hospedeiros, ampla gama de hospedeiros, o que auxilia na sua sobrevivência em campo, não são patogênicos a inimigos naturais e podem ser multiplicados tanto in vivo como in vitro. $\mathrm{Na}$ fase de juvenis infectivos os nematóides encapsulam células da bactéria simbiôntica e têm o trato digestivo desativado. Nesta fase estão aptos a suportar condições ambientais adversas, enquanto localizam um novo hospedeiro. Quando isso ocorre, invadem o corpo do inseto através de aberturas naturais, ou até mesmo através da cutícula intacta. Ao alcançarem a cavidade do corpo, liberam na hemolinfa células da bactéria simbiôntica, as quais multiplicam-se rapidamente e matam o inseto por 
septicemia em aproximadamente 24 a 48 horas. Então os nematóides se desenvolvem, alimentando-se da bactéria e alcançam o estágio adulto (Ferraz, 1998).

Molina-Ochoa et al. (1996) estudaram a eficiência de diferentes espécies de nematóides entomopatogênicos para $S$. frugiperda, e constataram que $H$. bacteriophora foi mais eficaz para a fase larval, causando $65 \%$ de mortalidade em lagartas de segundo ínstar.

\subsubsection{Atividade de Bacillus thuringiensis para Spodoptera frugiperda}

Em estudos iniciais, o $B t$ foi considerado pouco eficiente no controle de $S$. frugiperda. Porém, mais recentemente, com os avanços proporcionados por novas técnicas laboratoriais e maior interesse dos pesquisadores, resultados positivos foram obtidos.

Bohorova et al. (1996) testaram 352 isolados nativos do México e somente um causou mortalidade entre 70 e $80 \%$, enquanto 149 provocaram mortalidade entre 0 e 10\%. Hernandez (1988), também no México, testou 52 isolados de Bt em $S$. frugiperda e somente dois causaram mortalidade de $100 \%$. Dias et al. (1999) testaram 23 isolados argentinos contra lagartas de

terceiro ínstar de S. frugiperda e obtiveram 100\% de mortalidade para 8 deles. Arango et al. (2002) e Uribe et al. (2003), em estudos realizados na Colômbia, testaram 1.290 isolados de Bt contra $S$. frugiperda, obtendo resultados significativos para 11 destes, com $C_{50}$ variando de 11 a $962 \mathrm{ng}$ proteína $/ \mathrm{cm}^{2}$ dieta e mortalidade entre 70 e $95 \%$.

No Brasil vários estudos demonstram o potencial do $B t$ no controle de $S$. frugiperda (Correia, 1986; Habib et al., 1987; Rodrigues Júnior, 1990; Salvadori et al., 1986; Valicente et al.,1995; Valicente et al.,1996). Mais recentemente, Silva-Werneck et al. (2000) estudaram o efeito de 205 isolados de $B t$ sobre este lepidóptero e apenas um causou mortalidade de 
$100 \%$. Porém o isolado selecionado, denominado de Bt kurstakiS93 $\left(\mathrm{CL}_{50}\right.$ de $0,037 \mu \mathrm{g}$ proteína/mL dieta) mostrou-se 4.800 vezes mais tóxico para lagartas de terceiro ínstar que o Bt kurstaki HD-1 $\left(\mathrm{CL}_{50}\right.$ de 177,73 $\mu \mathrm{g}$ proteína/mL dieta). Loguercio et al. (2001) testaram 3.408 isolados nativos e somente $3,3 \%$ causaram mortalidade acima de $75 \%$, sendo que $52 \%$ do material testado mostrou-se pouco ativo (0 a 10\%). Fatoretto (2002), avaliou a eficiência de 115 isolados de $B t$, de várias regiões do Brasil, contra $S$. frugiperda obtendo $100 \%$ de mortalidade para 25 destes $(21,7 \%)$ e acima de $75 \%$ de mortalidade para 31 isolados (26,9\%). Por outro lado, $7,8 \%$ dos isolados testados foram inócuos ao inseto.

Bravo et al. (1998) caracterizaram as toxinas contidas em 1.948 isolados nativos do México, verificando que 246 destes continham 25 genes cry1 diferentes. Em testes realizados contra lagartas neonatas de $S$. frugiperda, os autores constataram maior atividade inseticida para as toxinas Cry 1C e Cry1D com a CL 50 variando entre 22 e 1124 ng proteína $/ \mathrm{cm}^{2}$ dieta. Resultados semelhantes foram obtidos por Aranda et al. (1996), que verificaram uma maior atividade tóxica de Cry1C e Cry1D $\left(\mathrm{CL}_{50}\right.$ de 31 e 77 ng proteína $/ \mathrm{cm}^{2}$ dieta, respectivamente) para a lagarta-do-cartucho em comparação com $\operatorname{Cry1A}(a, b, c)$, Cry1B, Cry1E. Bohorova et al. (1997) constataram que as toxinas mais ativas para este inseto foram Cry1D e Cry1F, causando mortalidade entre 90 e 100\%, com CL50 para Cry1D de $1,54 \mu \mathrm{g}$ toxina/g dieta artificial. Além desses trabalhos, Luo et al. (1999) testaram o efeito de diferentes toxinas de $B t$ contra $S$. frugiperda verificando que Cry1Bb e Cry1Fa foram as mais tóxicas para este inseto $\left(\mathrm{CL}_{50}\right.$ de $308 \mathrm{e}$ $109 \mathrm{ng}$ proteína $/ \mathrm{cm}^{2}$ dieta, respectivamente), enquanto que Cry $1 \mathrm{Ca}$ foi pouco tóxica ( $C L_{50}$ de $1144 \mathrm{ng}$ proteína $/ \mathrm{cm}^{2}$ dieta).

O Bt também pode ser utilizado em conjunto com outros entomopatógenos de controle, porém embora existam muitos estudos sobre as interações entre parasitóides, predadores e patógenos no controle de pragas, 
poucos são aqueles que tratam da interação entre entomopatógenos, principalmente quando envolvem espécies-praga de difícil controle. Neste sentido, são conhecidas interações entre $B$. bassiana, VPN, nematóides entomopatogênicos e $B t$ no controle de pragas (Alves \& Lecuona, 1998; Chang et al., 2003; Costa et al., 2001; El-Maghraby et al., 1998; Koppenhofer \& Kaya, 1997; Koppenhofer et al., 1999; Valicente et al., 2000; Vanninen \& Koskula, 2003). No entanto, em alguns casos, os resultados obtidos são conflitantes, muitas vezes variando para um único hospedeiro (Glare \& O'Callagham, 2000). 


\section{ISOLAMENTO E INFLUÊNCIA DAS CARACTERÍSTICAS QUÍMICAS DO SOLO NA OBTENÇÃO DE Bacillus thuringiensis}

\section{Resumo}

Foram analisadas 24 amostras de solos para verificar a presença de Bacillus thuringiensis $(B t)$. Baseando-se no método de isolamento proposta pela OMS, foram obtidas 461 colônias bacterianas, sendo que destas 190 (41,2\%) foram identificadas como $B t$. A relação entre o número de colônias bacterianas e as de $B t(i B t)$, variou de 0,24 a 0,69. Foi possível identificar, visualmente, a forma do cristal em $47,9 \%$ dos isolados obtidos, sendo o formato bipiramidal predominante (37\%). A análise da influência das características químicas de 8 amostras de solos na presença deste patógeno constatou que o $\mathrm{iBt}=-0,4+$ $0,6 \mathrm{Ca}+0,07 \mathrm{Cu}+0,009 \mathrm{Fe}-0,53 \mathrm{Mg}-0,12 \mathrm{Mn}+1,26 \mathrm{Zn}$, sugerindo que os elementos minerais podem restringir ou estimular o crescimento de $B t$ no solo.

\section{Summary}

To verifiy the presence of Bacillus thuringiensis $(B t) 24$ soil samples have been assayed. Using the method proposed by WHO it has been obtained 461 bacterian colonies, and $190(41.2 \%)$ were identified as $B t$. The relationship between the total number of bacterian colonies and those that belonged to $B t$ group ( $(B t)$, varied from 0.24 to 0.69 . The bipiramidal shape was the most common (37\%) in those isolates that it was possible to identify the crystal shape (47.9\%). The analyses of the soil chemical characteristics of 8 soil samples has showed that $\mathrm{i} B \mathrm{t}=-0,4+0,6 \mathrm{Ca}+0,07 \mathrm{Cu}+0,009 \mathrm{Fe}-0,53 \mathrm{Mg}-0,12 \mathrm{Mn}+1,26 \mathrm{Zn}$. 
This result enhance that the minerals elements may restrict or estimulate the $B t$ growth in the soil.

\subsection{Introdução}

O isolamento de $B t$, a partir de diversos substratos, é uma importante etapa do processo de seleção desse para o controle de pragas. Pelo estudo de novas toxinas é possível selecionar isolados mais virulentos, ampliar o espectro de ação e, conseqüentemente, aumentar o potencial de utilização deste microrganismo dentro do contexto do Manejo Integrado de Pragas.

O Bt é encontrado em todos os ambientes terrestres e também em insetos mortos, plantas e detritos (Bernhard et al., 1997; Chilcott \& Wigley, 1993; Dias et al.,1999; Forsyth \& Logan, 2000; Hongyu et al., 2000; Hossain et al., 1997; Kaur \& Singh, 2000; Maeda et al., 2000; Martínez \& Caballero, 2002; Phyllis \& Travers, 1989; Silva et al., 2002a; Uribe et al., 2003; Wang et al., 2003). Os métodos para isolar este patógeno são eficientes e normalmente de fácil execução (Saleh et al., 1969; Swiecicka et al., 2002; Travers et al., 1987; World Health Organization, 1985). O número de células obtidas de Bt varia entre $10^{2}$ e $10^{4}$ unidades formadoras de colônias (ufc) por grama de solo, enquanto que em plantas este número varia entre 0 e 100 ufc $\mathrm{cm}^{-2}$ (Damgaard, 2000).

Embora o solo seja uma das principais fontes de isolados de $B t$ (Damgaard, 2000; Glare \& O'Callagham, 2000), poucos estudos até o momento foram realizados no sentido de verificar a influência das características químicas e físicas desse substrato na obtenção deste patógeno (DeLucca et al., 1981; Hossain et al., 1997). O objetivo deste trabalho foi isolar Bt de amostras de solos, verificar a influência das características químicas dos solos na presença deste patógeno e caracterizar molecularmente os isolados obtidos. 


\subsection{Material e Métodos}

$\mathrm{O}$ isolamento de $\mathrm{Bt}$ e os estudos para se verificar a influência das características químicas do solo na obtenção desse patógeno foram conduzidos no Laboratório de Patologia e Controle Microbiano de Insetos do Departamento de Entomologia, Fitopatologia e Zoologia Agrícola da Escola Superior de Agricultura "Luiz de Queiroz", Universidade de São Paulo em Piracicaba-SP.

\subsubsection{Isolamento de Bacillus thuringiensis a partir de amostras de solos}

Para o isolamento, foram utilizadas 24 amostras de solos obtidas junto ao Laboratório de Análises de Solos (ESALQ/USP). Destas amostras, 4 foram coletadas em Campinas, 8 em Capão Bonito, 4 em Itapeva, 2 em Ourinhos, 3 em Piracicaba e 3 em São Paulo, todos municípios localizados no Estado de São Paulo. Nesse procedimento, o método utilizado foi adaptado do protocolo da Organização Mundial da Saúde (OMS), de 1985, onde cada amostra de $1 \mathrm{~g}$ de solo foi homogeneizado em $10 \mathrm{~mL}$ de solução salina $\left(0,006 \mathrm{mM} \mathrm{FeSO}{ }_{4} .7 \mathrm{H}_{2} \mathrm{O}\right.$; $0,01 \mathrm{mM} \mathrm{CaCO} 3.7 \mathrm{H}_{2} \mathrm{O} ; 0,08 \mathrm{mM} \mathrm{MgSO} 4.7 \mathrm{H}_{2} \mathrm{O} ; 0,07 \mathrm{mM} \mathrm{MnSO}_{4} .7 \mathrm{H}_{2} \mathrm{O} ; 0,006$ $\left.\mathrm{mM} \mathrm{ZnSO} \mathrm{Zn}_{4} .7 \mathrm{H}_{2} \mathrm{O} ; \mathrm{pH} 7,0\right)$ e submetida a agitação durante 24 horas. Uma alíquota de $1 \mathrm{~mL}$ foi transferida para tubo de microcentrífuga tipo "eppendorf" e, após choque térmico $\left(80^{\circ} \mathrm{C}\right.$ por 12 minutos) para eliminar as células vegetativas, foi diluída 10 e 100 vezes em solução salina. Uma alíquota de $100 \mu \mathrm{L}$ da última diluição foi distribuída em uma placa de Petri contendo ágar nutritivo $(0,5 \%$ extrato de levedura; $0,1 \%$ de triptona; $0,17 \mathrm{M} \mathrm{NaCl}$ e $0,15 \%$ de ágar bacteriológico). $\mathrm{O}$ material foi mantido em B.O.D., $30 \pm 0,5^{\circ} \mathrm{C}$ durante 48 horas.

As colônias obtidas foram avaliadas quanto à morfologia (forma, bordo, elevação, estrutura, tamanho e coloração), utilizando-se um Contador de Colônias modelo EC-550 A, selecionadas para as características correspondentes a bacilos e transferidas para meio, contendo penicilina $G$ a $100 \mathrm{mg} / \mathrm{L}$ seletivo para $B$. thuringiensis e Bacillus cereus (Jung et al., 1998). Os isolados inoculados foram mantidos $24 \mathrm{~h}$ a $30 \pm 0,5^{\circ} \mathrm{C}$ e $180 \mathrm{rpm}$ no agitador. 
Após este período cada amostra foi individualmente analisada quanto ao crescimento do microrganismo. Em seguida foram preparadas lâminas e observadas em microscopia de contraste de fase $(1.000 \mathrm{x})$, para a verificação da presença de corpos de inclusões parasporais (cristais) que permitem a diferenciação entre $B$. thuringiensis (com cristais) e $B$. cereus (sem cristais). Conforme Hossain et al. (1997), foi calculado o Índice Bt (iBt), que corresponde ao número de isolados de $B t$ obtidos em relação ao número de colônias examinadas em cada amostra.

\subsubsection{Influência das características químicas do solo na obtenção de Bacillus thuringiensis}

Neste estudo foram utilizadas 8 amostras de solos, provenientes dos municípios de Itapeva e Capão Bonito, em SP, e os parâmetros avaliados foram: $\mathrm{pH}, \mathrm{MO}, \mathrm{P}, \mathrm{K}, \mathrm{Ca}, \mathrm{Mg}, \mathrm{H}+\mathrm{Al}, \mathrm{B}, \mathrm{Cu}, \mathrm{Fe}, \mathrm{Mn}$ e $\mathrm{Zn}$ (Tabela 2) . No isolamento, cultivo bacteriano e avaliação foi utilizado o mesmo procedimento do item 3.2.1, sendo realizadas 4 repetições por amostra, totalizando 32 placas. Os dados (iBt) foram submetidos à análise de Cluster (Agrupamento - Distância Enclidiana Média e Método da Ligação Simples), complementada por uma análise de variância multivariada e regressão múltipla (Stepwise), conforme Silveira Neto (1986). 
Tabela 2. Características químicas dos solos que foram correlacionadas com a presença de Bacillus thuringiensis *

\begin{tabular}{ccccccccccccc}
\hline Amostra $^{1}$ & $\mathrm{pH}^{2}$ & $\mathrm{M}^{2} .^{3}$ & $\mathrm{P}^{4}$ & $\mathrm{~K}^{5}$ & $\mathrm{Ca}^{5}$ & $\mathrm{Mg}^{5}$ & $\mathrm{H}+\mathrm{Al}^{5}$ & $\mathrm{~B}^{4}$ & $\mathrm{Cu}^{4}$ & $\mathrm{Fe}^{4}$ & $\mathrm{Mn}^{4}$ & $\mathrm{Zn}^{4}$ \\
\hline 01 & 4,1 & 27 & 7 & 2,7 & 13 & 4 & 58 & 0,28 & 2,9 & 123 & 70 & 1,5 \\
02 & 3,9 & 32 & 6 & 0,7 & 1 & 1 & 109 & 0,23 & 1,1 & 83 & 1,2 & 0,2 \\
03 & 4,2 & 29 & 6 & 2,6 & 16 & 6 & 47 & 0,38 & 3,8 & 43 & 60,8 & 0,8 \\
04 & 3,7 & 31 & 5 & 0,8 & 1 & 1 & 88 & 0,30 & 1,3 & 43 & 0,4 & 0,2 \\
05 & 3,9 & 32 & 6 & 0,9 & 1 & 1 & 98 & 0,29 & 0,8 & 47 & 1,0 & 0,2 \\
06 & 3,9 & 29 & 6 & 0,7 & 1 & 1 & 72 & 0,29 & 0,5 & 50 & 0,4 & 0,1 \\
07 & 3,7 & 23 & 5 & 1,6 & 1 & 1 & 80 & 0,41 & 0,4 & 47 & 0,4 & 0,2 \\
08 & 4,0 & 21 & 5 & 0,5 & 2 & 2 & 58 & 0,24 & 0,4 & 45 & 0,6 & 0,2 \\
\hline
\end{tabular}

* Data da emissão da análise efetuada pelo Departamento de Solos (ESALQ/USP): 04/04/2001

${ }^{1}$ Amostras 1,2 e 3: Fazenda Campina (Itapeva-SP)

Amostras 4,5 e 6: Fazenda Valinhos (Capão Bonito - SP)

Amostras 6 e 7: Fazenda São Roque (Capão Bonito - SP)

${ }^{2} \mathrm{CaCl}_{2}$

${ }^{3} \mathrm{~g} \cdot \mathrm{dm}^{-3}$

${ }^{4} \mathrm{mg} \cdot \mathrm{dm}^{-3}$

${ }^{5} \mathrm{mmolc} \mathrm{dm}^{-3}$ 


\subsection{Resultados e Discussão}

\subsubsection{Isolamento de Bacillus thuringiensis a partir de amostras de solos}

No isolamento foram obtidas 461 colônias bacterianas, sendo destas 190 $(41,21 \%)$ identificadas como Bt. Em $21 \%$ dos isolados foi observada a presença de mais de um cristal, na maioria entre dois e quatro. Em 91 isolados (47,9\%) foi possível identificar visualmente a forma do cristal, sendo a forma bipiramidal a predominante (37\%) (Figura 1), seguida pela ovóide (23\%), retangular ou cubóide $(21 \%)$ e irregular (19\%). Nos isolados restantes, o aumento utilizado $(1.000 \mathrm{x})$ foi insuficiente para visualizar com clareza a forma dos cristais, sendo que na maioria esta se assemelhava a "ponto(s)".

De acordo com Glare \& O'Callagham (2000) os cristais têm formas diferentes e foi estudada a relação entre o seu formato e a especificidade inseticida. Os cristais bipiramidais são tóxicos para lepidópteros, enquanto que os ovóides ou cubóides mostram atividade para lepidópteros e dípteros. Berhnard et al. (1997) examinou a morfologia de cristais de 2.793 isolados e observou a predominância de cristais bipiramidais (49,5\%), 14,2\% esféricos, $4,4 \%$ retangulares ou cubóides, 16,4\% arredondados e 19,1\% em forma de pontos irregulares.

O índice de colônias de $B t$ em relação ao número de colônias bacterianas (iBt) variou de 0,24 a 0,69 (Tabela 3). Silva et al. (2002b), utilizando o mesmo método de isolamento, obtiveram índices de 0,04 a 0,16 para 144 amostras de solos processadas de várias regiões do Brasil. O valor médio, naquele trabalho, foi de 0,09 e para a região Sudeste foi de 0,07. 
Tabela 3. Isolados de Bacillus thuringiensis obtidos de amostras de solos do Estado de São Paulo

\begin{tabular}{|c|c|c|c|}
\hline Amostra & $\begin{array}{l}\text { Número de colônias } \\
\text { bacterianas (nCB) }\end{array}$ & $\begin{array}{c}\text { Número de colônias } \\
\text { de } B t(\mathrm{n} B t)\end{array}$ & $\begin{array}{c}\text { Índice } B t \\
(\mathrm{nBt} / \mathrm{nCB}) \times 100\end{array}$ \\
\hline 01 & 11 & 6 & 0,54 \\
\hline 02 & 18 & 9 & 0,50 \\
\hline 03 & 24 & 13 & 0,54 \\
\hline 04 & 20 & 9 & 0,45 \\
\hline 05 & 14 & 5 & 0,35 \\
\hline 06 & 16 & 7 & 0,43 \\
\hline 07 & 30 & 16 & 0,53 \\
\hline 08 & 18 & 9 & 0,50 \\
\hline 09 & 26 & 8 & 0,30 \\
\hline 10 & 29 & 9 & 0,31 \\
\hline 11 & 19 & 10 & 0,52 \\
\hline 12 & 11 & 6 & 0,54 \\
\hline 13 & 16 & 7 & 0,24 \\
\hline 14 & 27 & 8 & 0,29 \\
\hline 15 & 29 & 7 & 0,58 \\
\hline 16 & 20 & 5 & 0,25 \\
\hline 17 & 14 & 4 & 0,28 \\
\hline 18 & 19 & 7 & 0,36 \\
\hline 19 & 11 & 4 & 0,36 \\
\hline 20 & 22 & 6 & 0,27 \\
\hline 21 & 13 & 5 & 0,38 \\
\hline 22 & 15 & 9 & 0,60 \\
\hline 23 & 16 & 5 & 0,31 \\
\hline 24 & 23 & 16 & 0,69 \\
\hline TOTAL & 461 & 190 & 0,41 \\
\hline
\end{tabular}


Os elevados índices obtidos neste trabalho, em comparação com Silva et al. (2002b), podem ser explicados pela agitação das amostras de solos, antes do processo de isolamento. Segundo Valicente ${ }^{1}$, este movimento pode resultar na obtenção de um número maior de isolados de $B t$, pois libera os isolados da fração coloidal do solo. Outro fator, que pode explicar o sucesso do isolamento, é o método utilizado. De acordo com Silva et al. (2002b), o método da Organização Mundial da Saúde (World Health Organization, 1985) é o mais adequado, sendo superior aos métodos da filtração em algodão e do acetato para as condições climáticas e edáficas brasileiras.

Johnson \& Bishop (1996) propuseram um novo método de isolamento de Bt a partir de amostras de solos e compararam sua eficiência com outros métodos (Carozzi et al., 1991; Donovan et al., 1988; Meadows et al., 1992; Ohba \& Aizawa, 1986). Apesar do método proposto ser mais eficiente que os demais, ele é muito mais trabalhoso e de custo superior, por exemplo, que o método da OMS, pois envolve duas etapas com crescimento em meio líquido na presença de Penicilina.

Hossain et al. (1997) obtiveram iBt entre 0,44 e 0,77 em pesquisa realizada em terras agricultáveis de Bangladesh (Afeganistão). Neste trabalho os autores utilizaram um método que envolve o uso de choque térmico e acetato. Utilizando a técnica do acetato (Martin \& Travers,1989) obtiveram iBt entre 0,02 e 0,85 , sendo que o maior valor verificado para solos asiáticos e 0 menor encontrado em solos africanos.

Hossain et al. (1997) associaram o elevado número de isolados de Bt em amostras de solo à ocorrência de insetos nos locais onde foram coletadas as amostras, como ocorre na maioria dos países tropicais, facilitando a dispersão e multiplicação deste patógeno. Os dados dos referidos autores não estão de acordo com os citados por Chak et al. (1994), os quais mostram que $93,5 \%$ dos isolados obtidos têm como origem locais montanhosos, onde os insetos são raros

\footnotetext{
${ }^{1}$ VALICENTE, F.H. (EMBRAPA. Centro Nacional de Pesquisa de Milho e Sorgo). Comunicação pessoal, 1998.
} 
quando compararmos com as áreas de menor altitude. Assim sendo, fatores abióticos como vento e chuva podem favorecer a dispersão do microrganismo no ambiente.

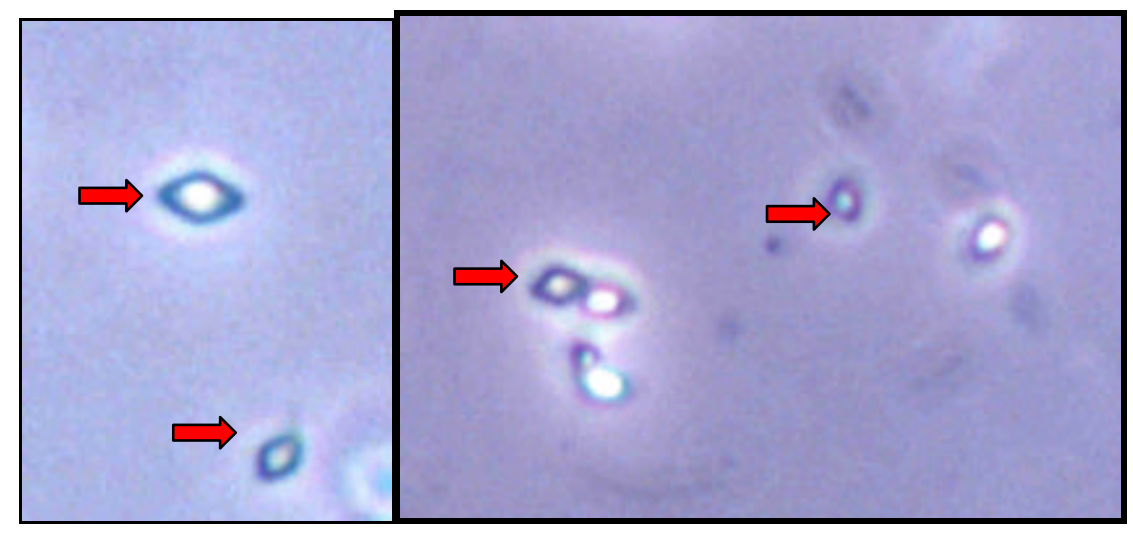

Figura 1 - Cristais bipiramidais do isolado ESALQ 3.7 de Bacillus thuringiensis obtidos a partir de amostras de solos (Laica DMLB/MPS 60, $1.000 \mathrm{x}$ )

A variação quantitativa de $B t$ em isolamentos realizados em diversos continentes pode ter uma série de razões, incluindo condições climáticas, atividade agrícola, tipos de solos e método de isolamento utilizado. Estes fatores dificultam comparações entre resultados, mas constituem base teórica importante em estudos sobre o papel ecológico desta bactéria no solo e também podem indicar o potencial tóxico de isolados obtidos em determinadas regiões sob condições ambientais e edáficas específicas.

Além disso, a ampla ocorrência do Bt em praticamente todos os ambientes terrestres, principalmente devido à sua capacidade de sobrevivência em condições adversas e fácil transporte pelo vento, chuva e animais, dificulta comparações entre os métodos de isolamento, especialmente entre regiões geograficamente distantes, com condições climáticas e solos distintos. Além do mais, a maioria dos estudos não levam em conta as características químicas e físicas dos solos amostrados. 


\subsubsection{Influência das características químicas do solo na obtenção de Bacillus thuringiensis}

No experimento realizado para verificar a influências das características químicas do solo, foi obtido um i Bt médio de 0,53 , sendo obtidos 268 isolados de $B t$, a partir de 500 colônias bacterianas (Tabela 4).

Tabela 4. Índice de Bacilus thuringiensis (iBt) obtido em diferentes amostras de solos de Itapeva e Capão Bonito (SP)

\begin{tabular}{cc}
\hline Amostra & iBt \\
\hline 1 & 0,35 \\
2 & 0,44 \\
3 & 0,59 \\
4 & 0,39 \\
5 & 0,74 \\
6 & 0,66 \\
7 & 0,55 \\
8 & 0,53 \\
Média & 0,53 \\
\hline
\end{tabular}

De acordo com a análise de Stepwise, o modelo se ajustou aos dados e o número de colônias de $B t$ obtidas pode ser expresso por i $B \mathrm{t}=-0,4+0,6 \mathrm{Ca}+$ $0,07 \mathrm{Cu}+0,009 \mathrm{Fe}-0,53 \mathrm{Mg}-0,12 \mathrm{Mn}+1,26 \mathrm{Zn}$. Em relação às colônias identificadas como pertencentes à $B t$, observou-se o agrupamento de amostras com menos colônias e uma correlação negativa significativa $(P=0,05)$ entre $M n$ e $\mathrm{Ca}, \mathrm{Mg}$ e $\mathrm{Ca}, \mathrm{Mg}$ e $\mathrm{Zn}, \mathrm{Mn}$ e $\mathrm{Zn}$ e uma correlação positiva significativa ( $\mathrm{P}$ = $0,05)$ entre $\mathrm{Mn}$ e $\mathrm{Mg}$, Zn e Ca. Embora estas correlações positivas e negativas entre esses elementos e a presença do $B t$ foram significativas, a sugestão é 
que estudos posteriores sejam realizados, pois os dados disponíveis até o momento não possibilitam uma interpretação biológica esclarecedora.

Visando identificar alguns parâmetros do solo que influenciam a presença de Bt, Hossain et al. (1997) obtiveram correlações positivas para Ca e $\mathrm{Cu}$. Os autores enfatizaram que a presença de Cu possivelmente contribui para a formação de esporos mais resistentes ao estresse ambiental ou inibe o desenvolvimento de microrganismos competidores. Já o Ca é necessário para a termoestabilidade dos esporos de Bt (Dulmage \& Rhodes, 1973) e para o crescimento celular e produção das $\delta$ endotoxinas (Sikdar et al., 1991).

Estudo detalhado sobre a influência do $\mathrm{Zn}$ no desenvolvimento do $B t$ foi realizado por Yao et al. (2002a). Os autores verificaram que em baixas concentrações (até $0,5 \mathrm{mg} / \mathrm{dm}^{3}$ ), este elemento auxilia na síntese do DNA e RNA celular. De 0,5 a $50 \mathrm{mg} / \mathrm{dm}^{3}$ ocorre a destruição das proteínas, impedindo o desenvolvimento celular normal, e quando na concentração de $60 \mathrm{mg} / \mathrm{dm}^{3}$, o desenvolvimento da bactéria é inviabilizado completamente. Estes resultados corroboram com os verificados no presente estudo, uma vez que em todas as amostras, com exceção da primeira, as concentrações de Zn são próximas ao valor de $0,5 \mathrm{mg} / \mathrm{dm}^{3}$ (Tabela 2), justificando a relação positiva entre esse elemento e a presença do patógeno nas amostras analisadas.

Em outro trabalho, Yao et al. (2002b) estudaram o efeito do Mn sobre Bt. Foi observado pelos autores que em altas concentrações (80 a 160 $\mathrm{mg} / \mathrm{dm}^{3}$ ) este elemento é importante para o patógeno, enquanto que em baixas concentrações (abaixo de $80 \mathrm{mg} / \mathrm{dm}^{3}$ ) foi verificado efeito contrário. Efeito semelhante foi observado neste trabalho, onde foi verificado interação negativa entre o $\mathrm{Mn}$ e a presença de $B t$, com todas as amostras tendo valores inferiores a $80 \mathrm{mg} / \mathrm{dm}^{3}$. De acordo com Dulmage \& Rhodes (1973), em concentrações adequadas este elemento é essencial para que o $B t$ inicie o processo de esporulação.

Embora Sikdar et al. (1991) tenham estabelecido o valor mínimo de $0,3 \mathrm{~g} / \mathrm{dm}^{3}$ de $\mathrm{MgSO}_{4}$ para a produção ótima das toxinas de $B t i$, no presente 
trabalho, apesar das concentrações de $\mathrm{Mg}$ estarem acima desse valor, sua relação negativa com o $\mathrm{Ca}$ e $\mathrm{Zn}$ prejudicou a presença do Bt nas amostras de solos analisadas. Os mesmos autores determinaram que a quantidade mínima de Fe, necessária para a produção destas toxinas, é de $0,0025 \mathrm{mg} / \mathrm{dm}^{3}$, sendo que os valores no presente trabalho estão bem acima deste limite, justificando assim a sua importância para a presença de $B t$ nas amostras analisadas.

Apesar de Dulmage \& Rhodes (1973) mencionarem que os sais inorgânicos (potássio, magnésio, fósforo, enxofre e menores quantidades de cálcio, zinco, ferro, cobalto, cobre, molibdênio, manganês e outros) são essenciais para o crescimento dos microrganismos, para $B t$ alguns deles, em determinadas concentrações ou na presença de outros elementos, podem influenciar negativamente a presença da bactéria, conforme verificado para o $\mathrm{Mn}$ e $\mathrm{Mg}$ neste trabalho. Porém, de um modo geral, a presença de alguns elementos é tão importante que existem processos fermentativos submersos para a produção de $B t$, no qual utiliza-se pequenas quantidades de cálcio, zinco, manganês e magnésio, como ingredientes essenciais.

De acordo com os resultados obtidos neste trabalho e os apresentados por Yao et al. (2002a e b), parece haver um limite quantitativo para cada elemento, podendo os sais inorgânicos, dependendo de sua concentração, inibir ao invés de favorecer o crescimento do Bt.

O solo constitui um ambiente complexo, influenciado por inúmeros fatores que governam a densidade das populações microbianas. No caso do $B t$, a sobrevivência dos seus esporos é essencial para sua permanência no solo. A distribuição de seus esporos no solo depende de fatores ecológicos que afetam a sua fecundidade e reciclagem, tanto pelo seu crescimento e multiplicação devido à presença de nutrientes necessários no solo ou pela reintrodução deste patógeno, seja pela imigração de insetos infectados ou pelo transporte pela água e vento. Embora Bt seja uma bactéria esporulante, Hossain et al. (1997) e Glare \& O'Callagham (2000) ressaltam que os esporos permanecem em latência no solo entre 3 e 16 meses. Portanto, a reciclagem deste patógeno é 
importante, porém o crescimento e germinação dos esporos pode ser prejudicada em solos arenosos, devido à pouca quantidade de nutrientes e água. Benz (1987) sugeriu que os microrganismos do solo são responsáveis pela perda da atividade da $\delta$-endotoxina e pela inativação parcial dos esporos. Embora o $\mathrm{pH}$ básico $(>7,0)$ seja o mais favorável para o crescimento do $B t$, valores mais baixos, como os verificados neste trabalho (Tabela 2), não inviabilizam a presença deste patógeno. Provavelmente, ele permanece latente nestas condições e quando encontra valores mais favoráveis, desenvolve-se normalmente.

\subsection{Conclusões}

O Bt é encontrado em todas as amostras de solos, sendo predominantes os produtores de cristais bipiramidais.

A presença do $\mathrm{Bt}$ no solo é favorecida pela presença do $\mathrm{Ca}, \mathrm{Cu}, \mathrm{Fe} \mathrm{e}$ $\mathrm{Zn}$, enquanto que $\mathrm{Mn}$ e $\mathrm{Mg}$ são elementos limitantes. 


\section{SELEÇÃO, EFEITOS SUBLETAIS DE Bacillus thuringiensis PARA Spodoptera frugiperda E CARACTERIZAÇÃO MOLECULAR DOS ISOLADOS}

\section{Resumo}

Foi realizada a seleção laboratorial de isolados de Bacillus thuringiensis $(B t)$ ativos para três diferentes populações de Spodoptera frugiperda (Minas Gerais, São Paulo e Rio Grande do Sul). A atividade foi medida por meio de testes de patogenicidade (para as três populações), virulência, estimativa da concentração letal média $\left(\mathrm{CL}_{50}\right)$ e efeitos subletais dos isolados sobre as lagartas sobreviventes (São Paulo). Foram testados 83 isolados para lagartas de segundo ínstar, destacando-se o ESALQ 3.7 que causou mortalidade de $86,6 \%$ para a população de São Paulo, sendo considerado o mais virulento e o mais promissor para o controle desta praga. Foi estimada a concentração letal média $\left(\mathrm{CL}_{50}\right)$ de $0,749 \times 10^{8}$ esporos $/ \mathrm{mL}$ deste isolado para esta população. Foram observadas diferenças na suscetibilidade entre as três populações da lagarta-do-cartucho do milho para $49,4 \%$ deles, sendo mais acentuadas para os isolados ESALQ 3.7 e 8.7. O pico da mortalidade nas três populações ocorreu três dias após a aplicação dos tratamentos, sem diferença estatística significativa entre elas. Foi observado efeito subletal de alguns isolados sobre os parâmetros biológicos avaliados (peso de lagarta e pupas fêmeas, oviposição e fecundidade dos ovos) e também uma correlação significativa entre os parâmetros avaliados. Os genes cry1 que codificam toxinas Cry específicas para lepidópteros foram encontradas em $72 \%$ dos isolados testados para a lagarta-docartucho, inclusive o ESALQ 3.7. Os isolados ESALQ 3.7 e ESALQ 2.4 amplificaram 
o maior número de genes da classe cry1 que codificam toxinas eficientes para $S$. frugiperda.

\section{Summary}

Laboratorial bioassays have been performed to verify the activity of Bacillus thuringiensis $(B t)$ on three different populations of Spodoptera frugiperda (Minas Gerais, São Paulo and Rio Grande do Sul). The isolate activity was measured by pathogenicity bioassays (for all populations), virulence, mean lethal concentration $\left(\mathrm{LC}_{50}\right)$ and the sublethal effects of isolates on larvae survival (São Paulo). 83 isolates were tested on second instar larvae. The isolate ESALQ 3.7 caused the mortality of $86.6 \%$ to São Paulo population, being the most virulent and promissing isolate to control of this pest. The $\mathrm{LC}_{50}$ value of $0.749 \times 10^{8}$ spores $/ \mathrm{mL}$ was obtained to this isolate in bioassays with São Paulo population. It has been observed differential susceptibility among the fall armyworm populations to the various $B t$ isolates tested (49.4\%), but it was more severe to the ESALQ 3.7 and 8.7. The highest mortality among all populations occurred three days after treatment application, but no statistical differences was observed. Sublethal effects have been observed on the biological parameters tested (larvae and female pupal weigh, oviposition, egg fecundity). Also, it was observed a significant correlation among the evaluated biological parameters and some $B t$ isolates. The $c r y 1$ genes that encodes Cry1 toxins specific against lepidopteran were present in $72 \%$ of isolates tested against fall armyworm, including ESALQ 3.7. The isolates ESALQ 3.7 e ESALQ 2.4 have the higher number os cry 1 genes that encodes toxins actives to $S$. frugiperda.

\subsection{Introdução}

$\mathrm{Na}$ fase de produção de bioinseticidas, a seleção de isolados virulentos é a mais importante. Para isso são realizados bioensaios de patogenicidade com objetivo de verificar se o patógeno tem efeito sobre o inseto-alvo, para determinar as curvas de mortalidade e virulência, visando selecionar os isolados mais promissores. Além destes parâmetros, os efeitos subletais do patógeno sobre o 
hospedeiro constituem um importante aspecto das relações patógeno $\mathrm{x}$ hospedeiro que, na maioria das vezes, não é considerado na condução dos bioensaios.

Aparentemente simples, o estudo da atividade tóxica de $B t$ tem algumas características específicas que devem ser consideradas. As diferenças entre cepas, origem dos insetos, métodos de bioensaios, dificuldade em determinar os componentes ativos deste patógeno e influência do ambiente e hospedeiro são alguns exemplos desta complexidade. Outro obstáculo é a falta de padronização dos termos $B t$, variedade, subespécie, serovar, toxinas e produtos, pois todos são usados para expressar virulência (Glare \& O'Callagham, 2000).

Em relação à atividade de $B t$ para $S$. frugiperda, Glare \& O'Callagham (2000) relataram 9 subespécies de Bt (aizawai, alesti, colmeri, darmstadiensis, kenyae, kurstaki, sotto, thuringiensis, tolworthi) que têm efeito sobre esta praga. No Brasil, as pesquisas iniciais realizadas determinaram que o uso de Bt no controle de S. frugiperda era pouco eficiente (Garcia et al., 1982; Lima \& Zanuncio, 1976). Porém, devido à necessidade de métodos de controle menos agressivos ao meio ambiente, de produtos com menores níveis de resíduos e a pouca eficiência dos agroquímicos utilizados, as pesquisas se voltaram para a busca de novos isolados deste patógeno para seu emprego no controle dessa praga, conforme as premissas do Manejo Integrado de Pragas.

Neste sentido, países da América Latina, como por exemplo Colômbia e Cuba, vêm utilizando produtos formulados com Bt para o controle de $S$. frugiperda. $\mathrm{Na}$ Colômbia, este biopesticida tem sido utilizado contra a lagarta-do-cartucho na cultura do algodão; em Cuba, para controle de pragas em hortaliças e tubérculos (Pérez \& Vasquez, 2001). A utilização desse patógeno, em ambos os casos, é o resultado direto de um programa envolvendo a seleção de isolados, caracterização, produção e formulação, disponibilizando ao agricultor um produto com menor impacto ambiental que os agroquímicos tradicionais, de menor custo, e que atua em conjunto com os agentes do controle biológico natural. Em outros países, como Brasil e México, os programas ainda encontram-se na fase de seleção de isolados, sendo que a produção nacional destes biopesticidas ainda 
não se iniciou, o que implica na utilização de produtos importados, com maior custo e muitas vezes sem a mesma eficiência verificada nos países de origem, desestimulando a utilização do $B t$.

Em uma etapa de seleção, após a identificação do $B t$, a caracterização molecular dos novos isolados é importante, pois a determinação das toxinas presentes direciona a pesquisa visando verificar o potencial destas contra determinados grupos de pragas, tanto agrícolas como urbanas. Neste sentido, a caracterização molecular do $B t$ utlizando-se a técnica da Reação em Cadeia de Polimerase (PCR) é uma técnica molecular amplamente utilizada pela sua eficiência, rapidez e repetibilidade (Ben-Dov et al., 1997; Bravo et al., 1998; Cerón et al., 1995; Chak et al., 1994; Ferrandis et al., 1999; Gleave et al., 1993; Valicente et al., 1998).

Com o intuito de selecionar isolado(s) com alto potencial de controle para S. frugiperda e verificar a influência da origem geográfica das populações na suscetibilidade ao $B t$, foram realizados ensaios laboratoriais com três populações da lagarta-do-cartucho. Foi também estudado os efeitos subletais destes isolados sobre lagartas pertencentes à população de São Paulo e realizou-se também a caracterização molecular dos isolados de $B t$ para verificar a presença de genes cry1, específicos para lepidópteros.

\subsection{Material e Métodos}

A criação dos insetos, testes de patogenicidade, estimativa da $C_{50}$ e avaliação dos efeitos subletais foram conduzidos no Departamento de Entomologia, Fitopatologia e Zoologia Agrícola da Escola Superior de Agricultura "Luiz de Queiroz" - Universidade de São Paulo. A caracterização molecular dos isolados de $B t$ foi realizada no Laboratório de Genética de Bactérias, do Departamento de Biologia da Universidade Estadual Paulista, em Jaboticabal-SP.

\subsubsection{Criação dos insetos}

A criação de $S$. frugiperda foi iniciada a partir de posturas coletadas no campo (população de São Paulo), indivíduos fornecidos pela EMBRAPA milho e sorgo (população de Minas Gerais) e pela Universidade Federal do Rio Grande do 
Sul (população do Rio Grande do Sul). Estas três populações foram iniciadas com insetos coletados em lavouras de milho, com cerca de 120 a 150 indivíduos. Os insetos foram mantidos no Laboratório de Resistência de Plantas a Insetos, onde as lagartas foram alimentadas em dieta artificial de Burton \& Perkins (1972) e os adultos com solução de açúcar $10 \%$. Os casais foram colocados em gaiolas, constituídas de tubos de PVC $(25 \times 10 \mathrm{~cm})$, revestidas internamente com papel filtro para coleta dos ovos a cada 2 dias. Dos ovos coletados, cerca de $10 \%$ foi utilizado para a manutenção da criação e o restante para a realização dos bioensaios. A cada 6 meses foi efetuada a reintrodução de novos espécimes com o objetivo de diminuir a degeneração da criação.

\subsubsection{Testes de patogenicidade}

Dentre os isolados de Bt obtidos a partir de amostras de solos (Capítulo 3), uma parte (83), foi utilizada nesses testes de patogenicidade. Os isolados foram multiplicados em meio de cultura BHI (Infusão de Cérebro e Coração Caldo BHI da AZ Labor) a $28{ }^{\circ} \mathrm{C}$, e $180 \mathrm{rpm}$ por 76 horas para um crescimento padrão dos mesmos. Após a lise bacteriana, a mistura contendo esporos, cristais e células vegetativas foi submetida a três centrifugações consecutivas $(5.000 \mathrm{rpm}$ por 20 minutos), a fim de eliminar o meio de cultura e lavar o concentrado obtido, eliminando toxinas extracelulares como as $\beta$-exotoxinas.

Após a multiplicação do isolado, uma alíquota de $1 \mathrm{~mL}$ foi diluída 1000 vezes em água destilada esterilizada, e a concentração de esporos foi determinada conforme método descrito por Alves \& Moraes (1998).

Para os bioensaios, uma alíquota de $100 \mu \mathrm{L}$ de suspensão de $B t$ na concentração de $3 \times 10^{8}$ esporos $/ \mathrm{mL}$, foi aplicada na superfície do disco de dieta artificial (Burton \& Perkins, 1972), previamente distribuída em placas de acrílico. Após a evaporação do excesso de umidade, 45 lagartas de segundo ínstar de cada população, distribuídas em três repetições, foram acondicionadas individualmente. No lote correspondente à testemunha foi aplicada água destilada e esterilizada, em volume equivalente aos lotes tratados. 
Para acondicionamento do material, foi utilizada câmara incubadora tipo Biological Oxigen Demand (B.O.D.), regulada para $25 \pm 0,5^{\circ} \mathrm{C}, 65 \pm 10 \%$ de UR e 12 horas de fotofase. Nesses bioensaios os tratamentos foram avaliados diariamente até $07^{\circ}$ após a aplicação da bactéria. Sempre que necessário, conforme a análise da variância, os dados foram submetidos ao Teste de Tukey a $5 \%$.

\subsubsection{Testes de estimativa da Concentração Letal Média $\left(\mathrm{CL}_{50}\right)$}

Os isolados de $B t$ ativos para a espécie-alvo foram submetidos a bioensaios para a estimativa da $\mathrm{CL}_{50}$, onde foram utilizados os mesmos substratos alimentares e condições de ambiente mencionadas nos bioensaios de patogenicidade.

A amplitude das concentrações testadas foi pré-estabelecida em ensaio preliminar, sendo aplicadas na superfície do substrato. No caso da testemunha, foi aplicado um volume de água esterilizada em substituição ao $B t$. Para cada isolado foram testadas seis concentrações logaritmicamente espaçadas, com três repetições de 40 insetos, totalizando 840 insetos por isolado. Foram utilizadas 4 lagartas de primeiro ínstar em cada recipiente $(8 \times 2,5 \mathrm{~cm})$ com dieta artificial (Burton \& Perkins, 1972). Os ensaios de estimativa da $\mathrm{CL}_{50}$ foram avaliados a cada 24 horas, até o quinto dia após a aplicação. $\mathrm{A} \mathrm{CL}_{50}$ foi estimada com a utilização do programa Polo-PC (Análise de Probit), conforme Haddad (1998).

\subsubsection{Efeitos subletais}

Neste item foram avaliados os parâmetros do desenvolvimento das lagartas de São Paulo sobreviventes aos tratamentos: peso da larva e pupas fêmeas, oviposição e fecundidade dos ovos. O peso das lagartas e pupas fêmeas (gramas) e oviposição (número de ovos) e sua fecundidade (porcentagem) observados nos tratamentos foram comparados estatisticamente com os da testemunha (Teste de Tukey a 5\%). Para avaliar a capacidade de oviposição dos adultos, foram formados 9 casais individuais por tratamento, e a contagem dos 
ovos foi realizada no segundo dia após a formação dos casais (item 4.2.1). Para a contagem dos ovos, foi utilizado método proposto por Leuck \& Perkins (1972), no qual conta-se o número de ovos na camada superior, multiplica-se pelo número de camadas e, posteriormente, conta-se os ovos em torno das camadas. Foi utilizada análise de correlação para verificar a interação entre os fatores peso de lagarta e pupa, oviposição e fecundidade de ovos.

\subsubsection{Caracterização molecular dos isolados de Bacillus thuringiensis}

\subsubsection{Extração de DNA pelo Kit InstaGene Matrix (Bio-Rad)}

Nas análises feitas por PCR, o material genético de cada um dos isolados provenientes de amostras de solos e testado para $S$. frugiperda foi obtido com a utilização da resina de troca iônica InstaGene Matrix, produzida pela BioRad, seguindo-se as instruções do fabricante:

As colônias isoladas foram obtidas pela inoculação de uma alíquota da solução estoque de esporos, em placas de Petri, contendo meio BHI (Meio Infusão de Cérebro e Coração), incubadas em B.O.D., a $30 \pm 0,5^{\circ} \mathrm{C}$ por $12 \mathrm{~h}$ e suspensas novamente em tubos para microcentrífuga de $1,5 \mathrm{~mL}$ contendo $1,0 \mathrm{~mL}$ de água destilada esterilizada e centrifugadas a $15.000 \mathrm{~g}$ por 2 minutos. O sobrenadante foi descartado e o precipitado resuspenso em $200 \mu \mathrm{L}$ da resina Instagene Matrix. As suspensões obtidas onde estava o DNA foram incubadas a $56^{\circ} \mathrm{C}$ por 30 minutos. Em seguida, os tubos foram agitados vigorosamente por 10 segundos e centrifugados a $15.000 \mathrm{~g}$ por 5 minutos. A seguir, foi transferido cerca de $200 \mu \mathrm{L}$ com o DNA obtido para outro tubo esterilizado. O DNA foi armazenado $\mathrm{a}-20^{\circ} \mathrm{C}$ até sua utilização.

A quantificação do DNA das amostras foi realizada em espectrofotômetro (BECKMAN - DU 640), medindo-se a absorbância nos comprimentos de onda de 260 a $280 \mathrm{~nm}$. Para estimar a concentração do DNA total utilizou-se o conceito padrão de que uma unidade de absorbância na 
densidade óptica de $260 \mathrm{~nm}\left(\mathrm{DO}_{260}\right)$ equivale a $50 \mu \mathrm{g}$ de $\mathrm{DNA}$ por $\mathrm{mL}$ de solução (Sambroock et al., 1989).

\subsubsection{Amplificação do DNA genômico e análise do produto amplificado}

Nas reações de amplificação para Cry1 foram conduzidas em um volume total de $20 \mu \mathrm{L}$ contendo: $30 \mathrm{ng}$ de DNA molde; $250 \mu \mathrm{M}$ de uma solução de dNTP's; 2,0 mM de $\mathrm{MgCl}_{2}, 0,2 \mu \mathrm{M}$ do iniciador, solução tampão para reação de PCR 1X concentrada (Invitrogen); $1 \mathrm{U}$ da enzima Taq polimerase (Invitrogen) (Fatoretto, 2002). As reações de amplificação dos diferentes Cry1 (Aa, Ab, Ac, B, $\mathrm{C}, \mathrm{D}, \mathrm{E}$ e F) foram conduzidas em um volume total de $25 \mu \mathrm{L}$ contendo: $30 \mathrm{ng}$ de DNA molde; $250 \mu \mathrm{M}$ de uma solução de dNTP's; $1,5 \mathrm{mM}$ de $\mathrm{MgCl}_{2}, 0,2 \mu \mathrm{M}$ do iniciador, solução tampão para reação de PCR 1X concentrada (Invitrogen); 2,5 U da enzima Taq polimerase (Invitrogen) (Bourque et al., 1993; Bravo et al., 1998; Cerón et al., 1994).

As reações foram conduzidas em termociclador modelo PTC $-100^{\mathrm{TM}}$ (MJ Research), equipado com circuito Hot Bonnet onde foi utilizado o seguinte programa: um passo inicial para desnaturação por $2 \min$ a $95^{\circ} \mathrm{C}$ e 30 ciclos consistindo de um ciclo de desnaturação a $95^{\circ} \mathrm{C}$ por 1 minuto; pareamento a $52^{\circ} \mathrm{C}$ por 1 minuto e extensão a $72^{\circ} \mathrm{C}$ por 5 minutos. Ao fim de cada programa foi adicionado um passo único para manutenção da amostra a $10^{\circ} \mathrm{C}$ até a retirada dos tubos do termociclador (Bravo et al., 1998).

Em todos o lotes de reações de amplificação foi realizado um controle negativo onde foi adicionada água grau Milli-Q previamente esterilizada em substituição ao DNA. Para Cry1A(a,b,c), Cry1B e Cry1D foi utilizado Bt kurstaki como controle positivo, enquanto que para Cry $1 \mathrm{C}$, Cry $1 \mathrm{E}$ e Cry $1 \mathrm{~F}$ foi utilizado o $\mathrm{Bt}$ aizawai.

Todos os produtos amplificados foram analisados por eletroforese em gel de agarose 1,5\% (Sambroock et al., 1989). Foi aplicada uma amostra de DNA contendo fragmentos de tamanho conhecido, múltiplos de $1 \mathrm{~kb}$ (1 kb ladder, GIBCO/BRL), com o objetivo de servir como referência de migração eletroforética 
para cálculo do tamanho dos fragmentos obtidos nas reações de amplificação. As eletroforeses foram realizadas em cubas horizontais modelos HORIZON 58 e HORIZON 11-14, utilizando tampão TBE. A corrente elétrica de migração foi de aproximadamente $70 \mathrm{~V}$ por $2,5 \mathrm{~h}$. Os fragmentos de DNA foram visualizados pela incidência de luz UV e documentados em um fotodocumentador modelo GEL DOC 2000 (BIO-RAD) e avaliados usando a imagem negativa. Para verificar a reprodutibilidade da metodologia, depois de padronizadas, foram realizadas três amplificações com cada oligonucleotídeo para cada amostra.

Tabela 1. Iniciadores utilizados nas reações de amplificação (PCR) dos isolados de Bacillus thuringiensis testados para Spodoptera frugiperda

\begin{tabular}{|c|c|c|c|}
\hline Iniciadores & Seqüências & Genes reconhecidos & $\begin{array}{l}\text { Pares de bases } \\
\text { amplificados (pb) }\end{array}$ \\
\hline Gral-Cry 1-1 & 5'CTGGATTTACAGGTGGGGATAT3' (d) & cry $1 A$, cry $1 B$, cry $1 C$ & \\
\hline Gral-Cry1-2 & 5'TGAGTCGCTTCGCATATTTGACT3' (r) & $\begin{array}{c}\text { cry } 1 D, \text { cry } 1 E, \text { cry } 1 F, \\
\text { cry } 1 G, \text { cry } 1 \mathrm{H}, \text { cry } 1 \text {, } \\
\text { cry } 1 \mathrm{~J} \text { e cry } 1 \mathrm{~K}\end{array}$ & $543-564$ \\
\hline \multirow[t]{2}{*}{ Cry $1 \mathrm{Aa}$} & 5' ATATTTCCTTGTCGCTAACGC3' (d) & cry $1 A a$ & $\cong 850$ \\
\hline & 5' CTGTTATTTGATGCCCTGACC3' (r) & & \\
\hline \multirow[t]{2}{*}{ Cry1Ab } & 5' CGGGATTAGAGCGTGTATG 3' (d) & cry $1 A b$ & $\cong 550$ \\
\hline & 5' CATCCAGCGAATCTACCG 3' (r) & & \\
\hline \multirow[t]{2}{*}{ Cry1Ac } & 5’ATCGCTCGTCTATCGGCATTG3' (d) & $\operatorname{cry} 1 A c$ & $\cong 400$ \\
\hline & 5'AGCCAGCCCTCACGTTCTTC3' (r) & & \\
\hline \multirow[t]{2}{*}{ Cry1B } & 5'TACAGATACCCTTGCTCGTG3' (d) & cry1B & $\cong 750$ \\
\hline & 5'GGTGTTGATAAAGGAGGGAG3' (r) & & \\
\hline \multirow[t]{2}{*}{ Cry $1 \mathrm{C}$} & 5'GAAGTGTGGAGAACCGAATC3' (d) & $\operatorname{cry} 1 C$ & $\cong 590$ \\
\hline & 5'TGGGATAACAAGGACCGAAC3' (r) & & \\
\hline \multirow[t]{2}{*}{ Cry1D } & 5'GTGGTGAATGCCCTGTTTAC3' (d) & $\operatorname{cry} 1 D$ & $\cong 676$ \\
\hline & 5'TCACCCATACACCTAAGTCCTC3' (r) & & \\
\hline \multirow[t]{2}{*}{ Cry1E } & 5’TCCGCAACTCCAATAGGG3' (d) & cry1E & $\cong 380$ \\
\hline & 5'AAGCCTGCCCAAACACTG'3 (r) & & \\
\hline \multirow[t]{2}{*}{ Cry1F } & 5'TGTAGAGCCGTTTGTTAGTG3' (d) & cry $1 F$ & $\cong 682$ \\
\hline & 5'GCTTGGGAATAGTGCGAC3' (r) & & \\
\hline
\end{tabular}

(d) direto; (r) reverso; $(\mathrm{pb})$ pares de bases. 


\subsection{Resultados e Discussão}

\subsubsection{Testes de patogenicidade}

Os 83 isolados de $B t$ foram testados em oito bioensaios, para as três populações de S. frugiperda (São Paulo, Minas Gerais e Rio Grande do Sul) (Tabela 5). Ao analisar os dados obtidos, observou-se uma alta relação entre os isolados e as populações em todos os experimentos realizados.

No terceiro bioensaio, o isolado ESALQ 3.7 destacou-se dos demais por ser o mais ativo para lagartas pertencentes à população de São Paulo, sendo também significativamente superior em relação às outras duas populações (Minas Gerais e Rio Grande do Sul). No quinto bioensaio o isolado ESALQ 6.6, destacouse como mais ativo para insetos do Rio Grande do Sul, sendo estatisticamente superior aos demais, porém não foi observada diferença significativa na suscetibilidade entre populações. No sétimo bioensaio, o isolado ESALQ 8.7 foi estatisticamente superior aos demais tratamentos na população de São Paulo e também na comparação com as outras populações. Nos demais bioensaios nenhum isolado destacou-se estatisticamente dos demais. Em relação às diferenças de suscetibilidade entre as populações, embora tenha sido observada diferença estatística significativa para outros 39 isolados, esta variação foi mais acentuada nos isolados ESALQ 3.7 e 8.7.

Pashley (1988) verificou diferenças entre populações de $S$. frugiperda que se alimentam de plantas hospedeiras diferentes. $O$ autor ressalta que esta diferenciação pode ter três causas: surgimento de novos biótipos, nos quais as diferenças genéticas podem ser devidas ao polimorfismo seletivo que ocorre dentro de uma espécie que acasala ao acaso, formação de raças no estágio inicial de especialização, no qual o intercruzamento é reduzido devido às diferenças na preferência por hospedeiros, ou são espécies "irmãs" que são capazes de hibridizar em um determinado nível ou se reproduzir isoladamente. 
Tabela 5. Atividade de isolados de Bacillus thuringiensis para lagartas de segundo ínstar de três diferentes populações de Spodoptera frugiperda (São Paulo, Minas Gerais e Rio Grande do Sul)

\begin{tabular}{|c|c|c|c|c|c|c|c|c|c|}
\hline \multirow[b]{2}{*}{ Tratamento } & \multicolumn{9}{|c|}{ Mortalidade (\%)* } \\
\hline & \multicolumn{3}{|c|}{ SP } & \multicolumn{3}{|c|}{ MG } & \multicolumn{2}{|l|}{$\mathrm{RS}$} & \multirow[t]{2}{*}{ Média } \\
\hline \multicolumn{9}{|c|}{ BIOENSAIO 1} & \\
\hline ESALQ 1.6 & $28,86 \pm 4,4$ & a & $A$ & $13,30 \pm 0$ & $a b c$ & $\mathrm{~B}$ & $19,96 \pm 7,7 a b$ & $A B$ & $20,71 \pm 3,4$ \\
\hline ESALQ 2.3 & $26,63 \pm 6,6$ & $a b$ & $A$ & $17,76 \pm 2,2$ & $a b c$ & $A$ & $26,63 \pm 6,6 a$ & A & $23,67 \pm 3,1$ \\
\hline ESALQ 2.1 & $19,96 \pm 7,7$ & $a b c$ & $A$ & $11,06 \pm 2,2$ & $a b c$ & $A$ & $6,60 \pm 0$ & $A$ & $12,54 \pm 3,0$ \\
\hline ESALQ 1.3 & $19,96 \pm 7,7$ & $a b c$ & $A B$ & $26,63 \pm 6,6$ & $a$ & $A$ & $6,53 \pm 3,7 \quad b c$ & $B$ & $17,71 \pm 4,3$ \\
\hline ESALQ 1.5 & $13,33 \pm 6,6$ & abcd & $A B$ & $19,96 \pm 7,7$ & $a b$ & $A$ & $\mathrm{C}$ & $B$ & $11,10 \pm 4,1$ \\
\hline Testemunha & $13,30 \pm 0$ & abcd & $A B$ & 0 & c & B & $15,53 \pm 2,2 a b c$ & A & $9,61 \pm 2,5$ \\
\hline ESALQ 1.4 & $8,86 \pm 4,4$ & bcd & A & 0 & c & $A$ & $4,40 \pm 2,2 \quad b c$ & $A$ & $4,42 \pm 1,9$ \\
\hline ESALQ 2.2 & $8,83 \pm 2,2$ & bcd & A & 0 & c & $A$ & $4,40 \pm 2,2 \quad b c$ & $A$ & $4,41 \pm 1,5$ \\
\hline ESALQ 1.2 & $6,60 \pm 0$ & $\mathrm{~cd}$ & A & $4,40 \pm 2,2$ & bc & $A$ & $11,06 \pm 2,2 \quad a b c$ & A & $7,35 \pm 1,3$ \\
\hline ESALQ 1.1 & 0 & d & $A$ & $6,60 \pm 0$ & $\mathrm{bc}$ & $A$ & $4,40 \pm 4,4 \quad b c$ & $A$ & $3,67 \pm 1,6$ \\
\hline Média & $14,63 \pm 2,0$ & & & $9,73 \pm 1,8$ & & & $9,95 \pm 1,7$ & & \\
\hline \multicolumn{10}{|c|}{ BIOENSAIO 2} \\
\hline ESALQ 2.4 & $46,66 \pm 0$ & $\mathrm{a}$ & A & $13,33 \pm 6,6$ & $a b$ & & $26,66 \pm 6,6 a b$ & B & $28,87 \pm 5,5$ \\
\hline ESALQ 3.1 & $26,67 \pm 0$ & $a b$ & A & $33,29 \pm 0$ & a & A & $13,33 \pm 6,6 \quad b c$ & B & $24,43 \pm 3,5$ \\
\hline ESALQ 3.3 & $26,63 \pm 6,6$ & $a b$ & $A$ & $28,86 \pm 4,4$ & $\mathrm{a}$ & $A$ & $35,50 \pm 8,5 a$ & $A$ & $30,33 \pm 3,1$ \\
\hline
\end{tabular}


Tabela 5. Atividade de isolados de Bacillus thuringiensis para lagartas de segundo ínstar de três diferentes populações de Spodoptera frugiperda (São Paulo, Minas Gerais e Rio Grande do Sul)

\begin{tabular}{|c|c|c|c|c|c|c|}
\hline \multirow{3}{*}{$\begin{array}{l}\text { Tratamento } \\
\text { ESALQ } 2.9\end{array}$} & \multicolumn{6}{|c|}{ Mortalidade (\%)* } \\
\hline & SP & \multicolumn{2}{|l|}{ MG } & \multicolumn{2}{|l|}{$\mathrm{RS}$} & \multirow{2}{*}{$\frac{\text { Média }}{11,82 \pm 3,4}$} \\
\hline & $19,96 \pm 13,3$ bc $A$ & $6,63 \pm 3,8 \quad b$ & A & $8,86 \pm 4,4 \quad b c$ & $A$ & \\
\hline ESALQ 2.8 & $15,53 \pm 2,2 \quad b c A$ & $b$ & B & $26,63 \pm 6,6 a b$ & A & $14,05 \pm 4,3$ \\
\hline ESALQ 2.7 & $13,33 \pm 6,6$ bc $A$ & $13,30 \pm 0 \quad a b$ & $A$ & $19,96 \pm 7,7 \quad a b c$ & $A$ & $15,53 \pm 3,1$ \\
\hline Testemunha & $13,30 \pm 0$ & $20,00 \pm 0 \quad a b$ & $A$ & $13,33 \pm 6,6 \quad b c$ & $A$ & $15,54 \pm 2,2$ \\
\hline ESALQ 3.4 & $11,06 \pm 2,2$ bc $A B$ & $b$ & B & $20,00 \pm 0 \quad a b c$ & $A$ & $10,35 \pm 2,9$ \\
\hline ESALQ 2.5 & $6,66 \pm 0$ & $4,43 \pm 4,4 \quad b$ & $A$ & $13,30 \pm 0$ & $A$ & $8,13 \pm 1,8$ \\
\hline ESALQ 3.2 & $C B$ & $19,96 \pm 7,7 \mathrm{ab}$ & $A$ & bc & B & $6,65 \pm 4,0$ \\
\hline ESALQ 2.6 & $c A$ & $6,63 \pm 3,8 \quad b$ & $A$ & $6,63 \pm 3,9 \quad c$ & $A$ & $4,42 \pm 1,9$ \\
\hline Média & $16,34 \pm 2,4$ & $\begin{array}{r}13,31 \pm 2,1 \\
\text { BIOEI }\end{array}$ & NSAI & $16,74 \pm 2,1$ & & \\
\hline ESALQ 3.7 & $86,66 \pm 7,7 \mathrm{a}$ & $33,29 \pm 0 \quad a$ & B & $6,63 \pm 3,8 b c$ & C & $42,20 \pm 12,0$ \\
\hline ESALQ 3.8 & $31,06 \pm 7,9 b$ & $26,63 \pm 6,6 a b$ & $A$ & $6,60 \pm 0 \quad b c$ & B & $21,43 \pm 4,8$ \\
\hline ESALQ 3.6 & $26,67 \pm 0$ & $11,06 \pm 2,2 \mathrm{bcd}$ & $\mathrm{B}$ & $20,00 \pm 0 \quad a b$ & $A B$ & $19,24 \pm 2,3$ \\
\hline ESALQ 3.10 & $26,63 \pm 6,6$ bc $A$ & 0 & $\mathrm{~B}$ & $13,30 \pm 3,8 a b c$ & $A B$ & $13,31 \pm 4,4$ \\
\hline ESALQ 3.12 & $20,00 \pm 0$ & $4,40 \pm 2,2 \quad c d$ & $B$ & 0 & $\mathrm{~B}$ & $8,13 \pm 3,0$ \\
\hline ESALQ 4.1 & $13,33 \pm 6,6$ bcde $A$ & $8,83 \pm 2,2 \mathrm{bcd}$ & $A$ & $19,96 \pm 7,7 a b$ & $A$ & $14,04 \pm 3,4$ \\
\hline ESALQ 3.5 & $8,83 \pm 2,2$ & $26,63 \pm 6,6 a b$ & $A$ & $13,33 \pm 6,6 a b c$ & $A B$ & $16,26 \pm 3,8$ \\
\hline ESALQ 3.11 & $6,60 \pm 0$ & $19,96 \pm 7,7 \mathrm{abc}$ & $A$ & 0 & $\mathrm{~B}$ & $8,85 \pm 3,6$ \\
\hline Testemunha & $6,60 \pm 0$ & $13,33 \pm 6,6 \mathrm{bcd}$ & $A$ & 0 & $A$ & $6,64 \pm 2,7$ \\
\hline
\end{tabular}


Tabela 5. Atividade de isolados de Bacillus thuringiensis para lagartas de segundo ínstar de três diferentes populações de Spodoptera frugiperda (São Paulo, Minas Gerais e Rio Grande do Sul)

\begin{tabular}{|c|c|c|c|c|c|}
\hline \multirow[t]{2}{*}{ Tratamento } & \multicolumn{5}{|c|}{ Mortalidade (\%)* } \\
\hline & \multicolumn{2}{|l|}{ SP } & MG & $\mathrm{RS}$ & \multirow{2}{*}{$\frac{\text { Média }}{15,55 \pm 4,0}$} \\
\hline ESALQ 3.13 & 0 & e $B$ & $20,00 \pm 0 a b c$ & $26,67 \pm 0$ & \\
\hline ESALQ 3.9 & 0 & e $A$ & d A & $11,06 \pm 2,2 a b c$ & $3,68 \pm 1,9$ \\
\hline Média & $20,58 \pm 4,2$ & & $14,95 \pm 2,1$ & $10,70 \pm 1,7$ & \\
\hline \multicolumn{6}{|c|}{ BIOENSAIO 4} \\
\hline ESALQ 4.6 & $33,29 \pm 0 \quad a$ & $A$ & $15,53 \pm 2,2 \quad$ bc $B$ & $13,30 \pm 0$ & $20,71 \pm 3,2$ \\
\hline ESALQ 4.8 & $31,06 \pm 7,9 a b$ & $A$ & $19,90 \pm 0$ & $13,33 \pm 6,6$ bcd $B$ & $21,43 \pm 3,9$ \\
\hline ESALQ 5.1 & $26,63 \pm 6,6 a b c$ & $A$ & $39,96 \pm 7,7$ a $A$ & $35,50 \pm 10,1 \mathrm{a}$ & $34,03 \pm 3,9$ \\
\hline ESALQ 4.7 & \multicolumn{2}{|c|}{$17,76 \pm 2,2$ abcd $A$} & $6,43 \pm 3,8$ bc $A$ & $6,60 \pm 0$ & $10,26 \pm 2,2$ \\
\hline ESALQ 4.5 & $13,30 \pm 0$ & $A$ & $15,53 \pm 2,2$ bc $A$ & $19,96 \pm 7,7 \quad$ abc $\quad A$ & $16,26 \pm 2,5$ \\
\hline Testemunha & $13,30 \pm 0$ & $A$ & $20,00 \pm 0$ & $6,60 \pm 0$ & $13,30 \pm 1,9$ \\
\hline ESALQ 4.2 & $8,86 \pm 4,3 \quad \mathrm{~cd}$ & $\mathrm{~B}$ & $13,33 \pm 6,6 \quad b c \quad A B$ & $26,67 \pm 0$ & $16,29 \pm 3,5$ \\
\hline ESALQ 4.3 & $6,63 \pm 3,8$ & $A$ & $6,60 \pm 0$ & $13,33 \pm 6,6 \quad$ bcd $A$ & $8,85 \pm 2,4$ \\
\hline ESALQ 5.2 & $6,60 \pm 0$ & $A B$ & C B & $20,00 \pm 0$ & $8,86 \pm 2,9$ \\
\hline ESALQ 4.9 & 0 & $\mathrm{~B}$ & $20,00 \pm 0$ & $d A$ & $6,66 \pm 3,3$ \\
\hline ESALQ 4.4 & 0 & A & $6,63 \pm 3,8 \quad b c A$ & $6,60 \pm 0$ & $4,41 \pm 1,5$ \\
\hline Média & $14,31 \pm 2,1$ & & $14,90 \pm 2,0$ & $15,71 \pm 2,0$ & \\
\hline \multicolumn{6}{|c|}{ BIOENSAIO 5} \\
\hline ESALQ 6.6 & $31,00 \pm 0 \quad a$ & $A$ & $33,29 \pm 6,8 \mathrm{a}$ & $33,29 \pm 0 \quad a$ & $34,77 \pm 3,4$ \\
\hline ESALQ 6.4 & $26,60 \pm 0 \quad a$ & $A B$ & $33,29 \pm 6,6 \mathrm{ab} \quad A$ & $13,30 \pm 0 \quad$ bcd $B$ & $24,40 \pm 3,1$ \\
\hline ESALQ 6.2 & $22,16 \pm 4,4 a b \quad A$ & & $20,00 \pm 0$ & $13,33 \pm 6,6$ bcd $A$ & $18,50 \pm 2,6$ \\
\hline
\end{tabular}


Tabela 5. Atividade de isolados de Bacillus thuringiensis para lagartas de segundo ínstar de três diferentes populações de Spodoptera frugiperda (São Paulo, Minas Gerais e Rio Grande do Sul)

\begin{tabular}{|c|c|c|c|c|}
\hline \multirow[t]{2}{*}{ Tratamento } & \multicolumn{4}{|c|}{ Mortalidade $(\%)^{*}$} \\
\hline & SP & MG & \multirow{2}{*}{$\frac{\mathrm{RS}}{6,60 \pm 0}$} & \multirow{2}{*}{$\frac{\text { Média }}{11,05 \pm 3,1}$} \\
\hline ESALQ 6.3 & $19,96 \pm 7,7 a b \quad A$ & $6,60 \pm 0$ & & \\
\hline Testemunha & $13,33 \pm 6,6 a b c A$ & $15,53 \pm 2,2$ bcd $A$ & $6,63 \pm 3,8$ cd $A$ & $11,83 \pm 2,6$ \\
\hline ESALQ 7.1 & $13,30 \pm 0$ abc $A$ & $19,96 \pm 7,7$ bc $A$ & $26,60 \pm 0 \quad a b \quad A$ & $19,95 \pm 2,9$ \\
\hline ESALQ 6.1 & $13,30 \pm 0 \quad a b c A$ & $13,30 \pm 0$ & $20,00 \pm 0$ abc $A$ & $15,53 \pm 1,1$ \\
\hline ESALQ 5.4 & $6,63 \pm 3,8$ bc $A$ & $6,60 \pm 0$ & $13,33 \pm 6,6$ bcd $A$ & $8,85 \pm 2,4$ \\
\hline ESALQ 6.7 & $6,63 \pm 3,8$ bc $A B$ & $d B$ & $20,00 \pm 0$ abc $A$ & $8,87 \pm 3,1$ \\
\hline ESALQ 5.3 & $4,43 \pm 4,4$ bc $B$ & $6,66 \pm 6,6$ & $26,63 \pm 6,6$ ab $A$ & $12,57 \pm 4,6$ \\
\hline ESALQ 7.2 & $4,40 \pm 2,2$ bc $A$ & $11,06 \pm 2,2$ & $d A$ & $5,15 \pm 1,8$ \\
\hline ESALQ 6.5 & $C B$ & $20,00 \pm 0$ & $d B$ & $6,65 \pm 4,0$ \\
\hline ESALQ 5.5 & $C A$ & $8,83 \pm 2,2$ & $6,63 \pm 3,8$ & $5,15 \pm 1,8$ \\
\hline Média & $12,44 \pm 1,84$ & $15,52 \pm 2,0$ & $14,33 \pm 1,8$ & \\
\hline \multicolumn{5}{|c|}{ BIOENSAIO 6} \\
\hline ESALQ 7.7 & $31,00 \pm 7,9 a$ & $20,00 \pm 0$ & $13,30 \pm 0$ & $21,45 \pm 3,4$ \\
\hline ESALQ 7.9 & $26,63 \pm 6,6 a b \quad A$ & $33,29 \pm 3,8 a b \quad A$ & $8,86 \pm 4,4$ bcd $B$ & $22,93 \pm 4,4$ \\
\hline ESALQ 7.11 & $26,60 \pm 0 \quad a b \quad B$ & $40,00 \pm 0 \quad a$ & $33,29 \pm 0 \quad a$ & $33,29 \pm 1,9$ \\
\hline ESALQ 7.8 & $20,00 \pm 0 \quad a b c \quad A$ & $6,60 \pm 0$ & $6,63 \pm 3,8$ & $11,07 \pm 2,4$ \\
\hline ESALQ 7.6 & $13,33 \pm 6,6$ abcd $A$ & $13,30 \pm 0$ & $20,00 \pm 0 \quad a b c \quad A$ & $15,54 \pm 2,2$ \\
\hline ESALQ 7.13 & $13,33 \pm 0 \quad$ abcd $B$ & $20,00 \pm 0 \quad$ bc $\quad A B$ & $26,63 \pm 10,2 a b$ & $19,98 \pm 3,5$ \\
\hline Testemunha & $13,30 \pm 0 \quad$ abcd $A$ & $8,83 \pm 2,2 \quad \mathrm{~cd} A$ & $4,43 \pm 4,43$ cd $A$ & $8,85 \pm 1,9$ \\
\hline
\end{tabular}


Tabela 5. Atividade de isolados de Bacillus thuringiensis para lagartas de segundo ínstar de três diferentes populações de Spodoptera frugiperda (São Paulo, Minas Gerais e Rio Grande do Sul)

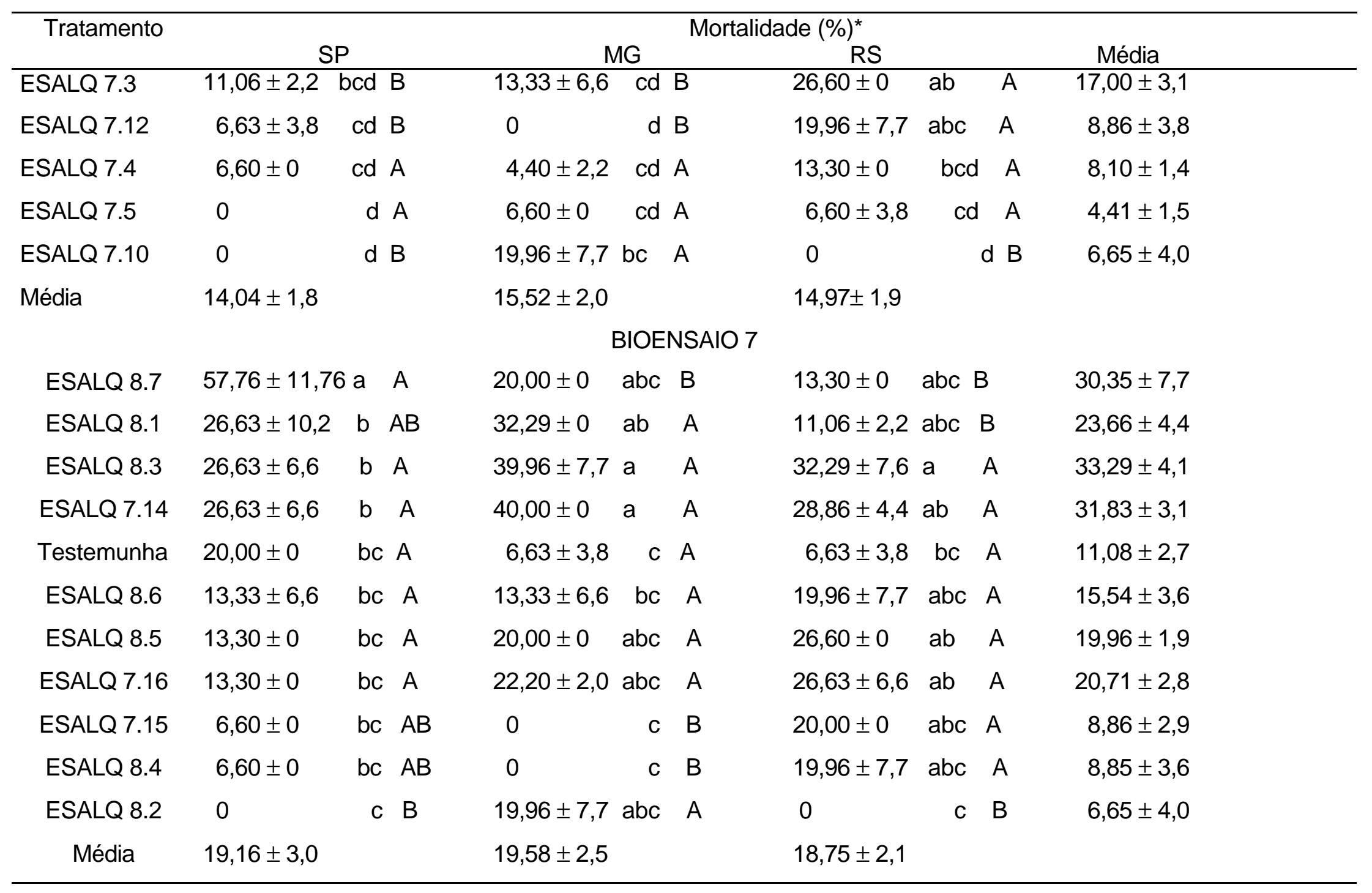


Tabela 5. Atividade de isolados de Bacillus thuringiensis para lagartas de segundo ínstar de três diferentes populações de Spodoptera frugiperda (São Paulo, Minas Gerais e Rio Grande do Sul)

\begin{tabular}{|c|c|c|c|c|c|c|}
\hline \multirow[t]{2}{*}{ Tratamento } & \multicolumn{6}{|c|}{ Mortalidade $(\%)^{*}$} \\
\hline & \multicolumn{2}{|c|}{ SP } & \multicolumn{2}{|l|}{ MG } & $\mathrm{RS}$ & \multirow{2}{*}{ Média } \\
\hline & & & $\mathrm{BIOEI}$ & ENSA & & \\
\hline ESALQ 9.1 & $39,96 \pm 13,8$ & $A$ & $26,60 \pm 0 \quad a$ & $A$ & $6,60 \pm 0 \quad a b \quad B$ & $22,38 \pm 6,2$ \\
\hline ESALQ 9.5 & $26,63 \pm 2,2$ & $a b \quad A$ & $22,20 \pm 2,1 \mathrm{ab}$ & $A$ & $13,30 \pm 0 \quad a b \quad A$ & $20,71 \pm 2,8$ \\
\hline ESALQ 8.8 & $26,63 \pm 6,6$ & $a b \quad A$ & $6,60 \pm 0$ & $A$ & $20,00 \pm 0 \quad a \quad A B$ & $17,74 \pm 3,5$ \\
\hline ESALQ 8.9 & $26,60 \pm 0$ & $a b \quad A$ & c & $A$ & $13,33 \pm 6,6$ ab $A B$ & $13,31 \pm 4,2$ \\
\hline ESALQ 9.4 & $20,00 \pm 0$ & bc $A$ & $6,60 \pm 0$ & $A$ & $6,63 \pm 3,8 a b \quad A$ & $11,07 \pm 2,4$ \\
\hline ESALQ 10.1 & $19,96 \pm 7,7$ & bc $A$ & $6,60 \pm 0$ & $A$ & $6,60 \pm 0 \quad a b \quad A$ & $11,05 \pm 3,1$ \\
\hline ESALQ 9.7 & $13,30 \pm 0$ & bcd $A$ & $13,33 \pm 6,6 a b c$ & $A$ & $19,96 \pm 7,7$ a $A$ & $15,53 \pm 3,1$ \\
\hline Testemunha & $11,06 \pm 2,2$ & bcd $A$ & $11,06 \pm 2,2 a b c$ & $A$ & $13,33 \pm 6,6$ ab $A$ & $11,83 \pm 2,1$ \\
\hline ESALQ 9.3 & $6,63 \pm 3,8$ & $\mathrm{~cd} A B$ & $20,00 \pm 0$ & A & b $B$ & $8,87 \pm 3,1$ \\
\hline ESALQ 9.8 & $6,60 \pm 0$ & $\operatorname{cd} A$ & $15,53 \pm 2,2 a b c$ & $A$ & $13,30 \pm 0 \quad a b \quad A$ & $11,81 \pm 2,4$ \\
\hline ESALQ 9.2 & 0 & d A & 0 & $A$ & $8,83 \pm 2,2 \quad a b \quad A$ & $2,94 \pm 1,6$ \\
\hline ESALQ 9.6 & 0 & d $B$ & $20,00 \pm 0 \quad a b$ & $A$ & $b \quad B$ & $6,66 \pm 3,3$ \\
\hline Média & $16,45 \pm 2,3$ & & $12,37 \pm 1,5$ & & $10,15 \pm 1,3$ & \\
\hline
\end{tabular}

* Médias seguidas da mesma letra não diferem estatisticamente (Tukey 5\%).

Letras maiúsculas: análise nas linhas. Letras minúsculas: análise nas colunas. 
Porém variações na suscetibilidade a $B t$ entre indivíduos de diferentes populações de $S$. frugiperda coletadas em um único hospedeiro (milho), foram pela primeira vez constatadas por López-Edwards et al. (1999). Os autores estudaram a suscetibilidade de lagartas de primeiro ínstar pertencentes a 5 populações mexicanas (Aguascalientes, Nuevo León, Colima, Sinaloa e Yucatán) para $B t$ kenyae. Insetos pertencentes às duas primeiras populações mostraram maior suscetibilidade a esta subespécie, sendo estimadas $C_{50}$ entre 0,001 e $0,005 \mathrm{mg}$ toxina/ $\mathrm{mL}$ de água destilada. Os autores enfatizam que esta variação pode ser devida ao isolamento geográfico, conseqüente isolamento reprodutivo, originando populações fisiologicamente diferentes, com suscetibilidade diferencial para o Bt.

Cabe ressaltar aqui a importância de estudar o hábito migratório da espécie em questão. Este movimento pode ser influenciado pelo clima, pela geografia do local e ainda pela preferência por hospedeiros. Nos EUA o hábito migratório dos noctuídeos foi bem estudado, especialmente porque estes insetos são pragas importantes em várias culturas. Foi observada a movimentação de populações de $S$. frugiperda entre o Mississipi e o Canadá e entre os EUA e o Golfo do México, indicando a grande capacidade de migração desta espécie. Porém, no Brasil, as condições climáticas e geográficas são diferentes daqueles países, não permitindo fazer generalizações sobre a capacidade migratória da lagarta-do-cartucho.

A variação na eficiência dos isolados testados em cada população, e entre as populações, pode ser explicada por uma série de fatores, relacionados ou não, ligados ao modo de ação deste patogéno, como: dissolução do cristal, ativação da protoxina e ligação da toxina ativada a receptores no epitélio intestinal, o último mostra uma maior complexidade funcional e é, geralmente, determinante no desenvolvimento da doença no inseto-alvo.

Os receptores geralmente são específicos para determinadas toxinas Cry, sendo que para algumas espécies já foram identificados os que estão presentes nas microvilosidades apicais do intestino médio. Para Manduca sexta, por exemplo, foi determinado que o receptor para Cry1Aa, Cry1Ab e Cry1C é uma 
N-aminopeptidase (glicoproteína) com peso molecular de 120 kDa e uma proteína do grupo caderina $\left(\mathrm{Ct}-\mathrm{R}_{1}\right)$, com peso molecular de $210 \mathrm{kDa}$. Várias $\mathrm{N}$ aminopeptidases foram identificadas como os principais receptores para Cry1 em Bombyx mori, H. virescens, L. dispar, M. sexta, Plutella xylostella e Trichoplusia ni. Além destes dois tipos, um terceiro foi encontrado em $M$. sexta, e identificado como um glicolipídeo (Garczynski \& Adang, 2000; Gómez et al., 2001). Para S. frugiperda, até o momento ainda não foram identificados os receptores envolvidos na ligação com as toxinas Cry.

Os receptores estão de alguma forma envolvidos na fisiologia do inseto, como por exemplo, as caderinas, são essenciais para a manutenção da solidez dos tecidos e também no arranjamento e rearranjamento celular que ocorre numerosas vezes, em tecidos neurais e não neurais, durante o desenvolvimento embrionário do inseto (Uemura, 1998).

Além da especificidade, algumas toxinas de Bt podem ligar-se ao(s) receptor(es) sem, no entanto, esta ligação ser suficiente para causar a morte do inseto. Aranda et al. (1996) realizaram estudo para verificar a interação entre as toxinas Cry e as células epiteliais do intestino médio de $S$. frugiperda. Os autores observaram que, embora as toxinas Cry1Aa, Cry1Ab, Cry1Ac e Cry2 B se liguem aos receptores, esta ligação não implica em toxicidade para o inseto. Isto se deve ao fato dessas toxinas apresentarem reduzida especificidade, resultando numa ligação pouco estável e reversível com o receptor, ou seja, a toxina apenas reconhece o receptor, mas não se liga irreversivelmente a ele. O contrário foi verificado para as toxinas Cry1C e Cry1D, altamente tóxicas para a lagarta-docartucho. Nestes casos, a ligação é estável e altamente específica, sendo suficiente para a formação do poro no epitélio e conseqüente morte do inseto.

As alterações fisiológicas e histológicas causadas pelo isolamento geográfico de populações de $S$. frugiperda podem levar a alterações qualitativas e quantitativas nos receptores das toxinas Cry, resultando na suscetibilidade diferencial a um determinado isolado de Bt. Como fator agravante desta complexidade, até o momento não foi publicado nenhum estudo sobre os receptores de Bt em $S$. frugiperda. 
A relação intrínseca entre as toxinas e seus receptores pode levar a efeitos antagônicos ou sinérgicos. Neste sentido, Lee et al. (1996) constataram efeito antagônico entre as toxinas Cry1 $\mathrm{Aa}$ e Cry1 Ab para Lymantria dispar. Porém os mesmos autores verificaram um efeito sinérgico entre Cry1Aa e Cry1Ac para a mesma espécie, resultando num aumento da toxicidade de 4 a 7 vezes. Os mesmos efeitos de interação podem ser observados para formulações. Ameen et al. (1998) observou efeito aditivo entre Xentari Es R e Dipel 6AF R para Heliothis virescens, porém entre Xentari e Dipel ES R foi observado efeito antagônico. Além dos lepidópteros, Glare \& O'Callagham (2000) listam vários exemplos de interação entre toxinas Cry para dípteros.

Embora a afinidade pelos receptores seja o principal fator que determine o nível de suscetibilidade de uma espécie para as toxinas Cry, Forcada et al. (1996) observaram que para $H$. virescens a ativação da protoxina pelas proteases é o principal fator determinante para eficiência do patógeno. Os autores verificaram que as enzimas digestivas da população de insetos resistentes são capazes de degradar as toxinas de modo tal que diminui significativamente a quantidade de toxina ativa no lúmen do intestino médio em um determinado momento, reduzindo a toxicidade.

Fica claro que na etapa de seleção de isolados de Bt para $S$. frugiperda, assim como para outros insetos, uma série de fatores afeta diretamente a suscetibilidade dos insetos. São necessários estudos posteriores para determinar as razões do sucesso ou não desta etapa. Por isso, é importante conhecer detalhadamente o inseto-alvo, seus hábitos, biologia, fisiologia e histologia e qual é a resposta do inseto para presença deste microrganismo.

Para fins de seleção, somente o isolado ESALQ 3.7, na população de São Paulo, atingiu um nível de mortalidade (86,6\%) suficiente para ser considerado promissor para o controle de $S$. frugiperda. Na Figura 1 pode-se observar a diferença entre a mortalidade acumulada deste isolado e a média dos outros tratamentos do mesmo bioensaio. Pelo ângulo de inclinação da linha de tendência (tracejada) (Figura 1), pode-se sugerir que este isolado é mais virulento que a média dos demais. 


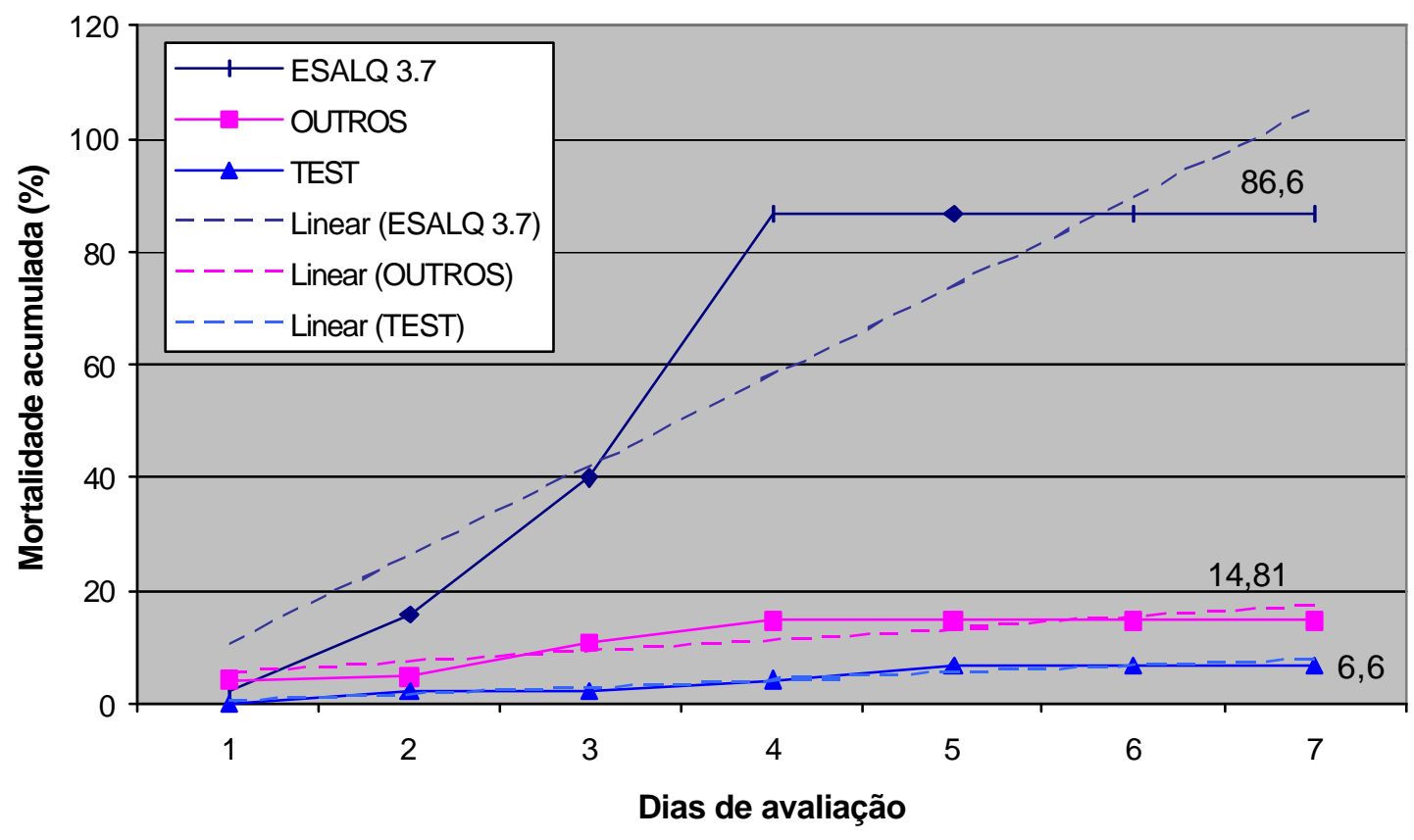

Figura 1 - Mortalidade acumulada do isolado ESALQ-3.7 e da média dos demais testados para lagartas de segundo ínstar de Spodoptera frugiperda, pertencentes à população de São Paulo (Bioensaio 3)

\subsubsection{Interação inseto x patógeno nas populações testadas}

Considerando todos os bioensaios em conjunto, foram utilizadas 11.202 lagartas, sendo que destas $1.697(15,12 \%)$ morreram devido ao efeito dos tratamentos. Deste total $585(5,22 \%)$ são insetos pertencentes à população de São Paulo, 570 (5,08\%) são oriundos de Minas Gerais e 543 (4,84\%) do Rio Grande do Sul. A distribuição da mortalidade ao longo do período de avaliação, entre as populações pode ser observada na Figura3.

A análise dos dados mostra que não houve diferença significativa nas três populações testadas em cada dia de avaliação, indicando que a doença desenvolveu-se de modo semelhante nos insetos testados. Porém, entre os dias de avaliação, pôde-se observar que no terceiro dia ocorreu a morte do maior 
número de insetos, seguido do segundo e quarto dias de avaliação e, posteriormente, pelo primeiro e quinto dias. Pelos polinômios obtidos foi possível calcular o dia que ocorreu o pico de mortalidade para cada população, sendo este valor de 3 dias para todas as populações testadas. Essas observações estão de acordo com a descrição da patologia de Bt em insetos feita por Knowles (1994). O mesmo autor afirma que morte por falta de alimento ou septicemia ocorre em um período de 1 a 3 dias.

Apesar do pico de mortalidade ocorrer três dias após a aplicação dos tratamentos (Figura 3), de acordo com Knowles (1994), a ingestão do Bt faz com que 0 inseto interrompa sua alimentação imediatamente após sua ingestão (1-5 minutos). Assim sendo, pode-se considerar que o $B t$ funciona como um inseticida de ação rápida, impedindo que o inseto danifique as plantas. Este rápida ação deve ser melhor explorado pelos profissionais envolvidos no processo de transferência dessa tecnologia para o agricultor, não somente ressaltando as vantagens ambientais de sua utilização, mas também mostrando que bioinseticidas baseados nesse patógeno, se corretamente aplicado, pode ser competir em eficácia e rapidez com os agrotóxicos convencionais.

\subsubsection{Testes de estimativa da concentração letal média $\left(C L_{50}\right)$}

Para estimar a $\mathrm{CL}_{50}$ do isolado ESALQ-3.7 para a população de São Paulo, inicialmente foi realizado ensaio preliminar para determinar as concentrações a serem utilizadas no experimento: $6 \times 10^{6}, 1,3 \times 10^{7}, 3 \times 10^{7}, 6,7 \times$ $10^{7}, 1,5 \times 10^{8}$ e $3 \times 10^{8}$ esporos $/ \mathrm{mL}$, logaritmicamente espaçadas. Para as outras duas populações não foi possível estimar a $\mathrm{CL}_{50}$, devido à baixa mortalidade observada (33,3\% e 6,6\% para lagartas de Minas Gerais e Rio Grande do Sul, respectivamente). Esses valores não atendem às exigências do teste de Probit, que necessita de índices de mortalidade entre 5-10\% e 80-95\% para determinação da reta (Figura 4). Por esse motivo, a comparação da eficiência deste isolado entre as três populações ficou restrita aos testes de patogenicidade (Tabela 5). 


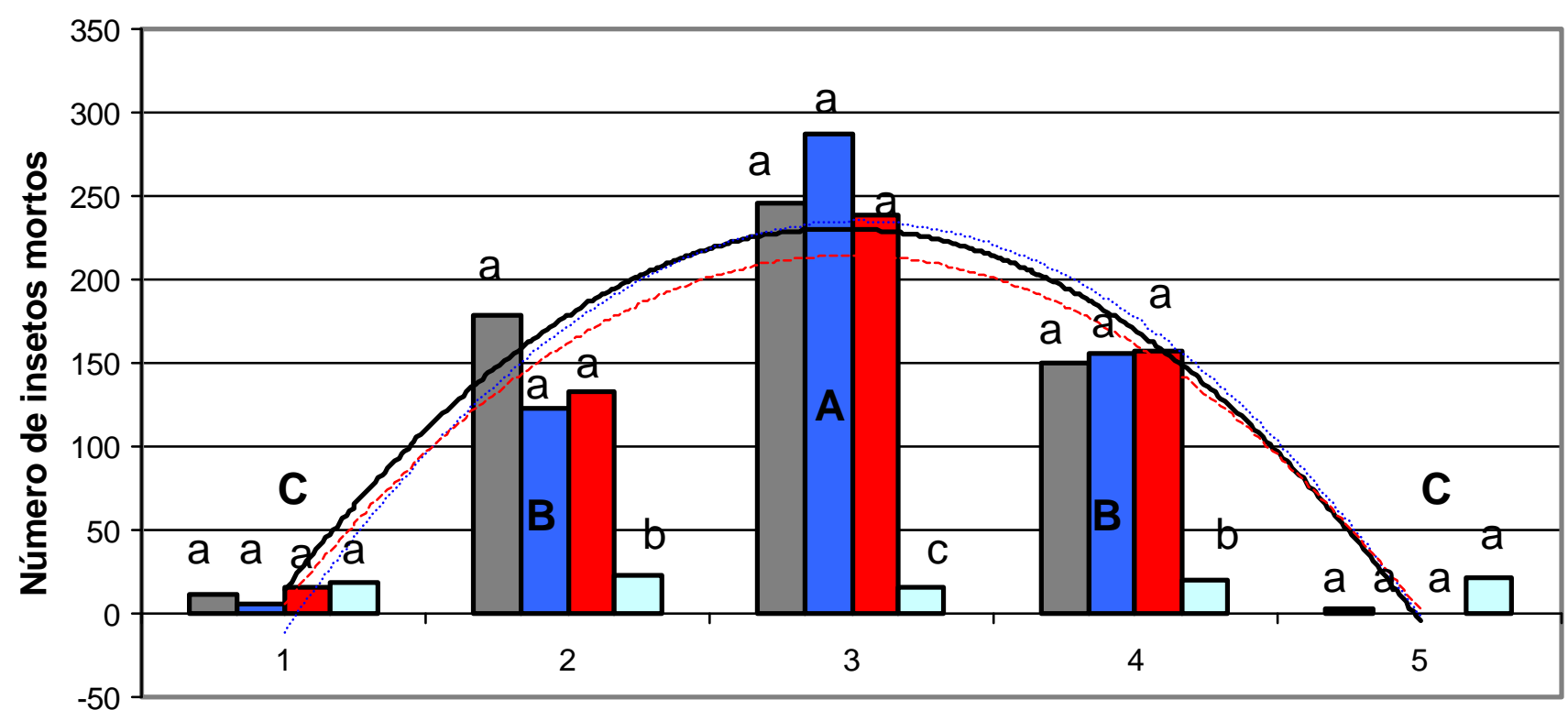

$y=-56,357 x^{2}+333,64 x-263,8$

$R^{2}=0,9847(P ? 0,01)$

$y=-60,143 x^{2}+363,26 x-314,2$

$R^{2}=0,8952(P ? 0,01)$

$y=-51,143 x^{2}+308,26 x-253,6$

$R^{2}=0,9693(P ? 0,01)$

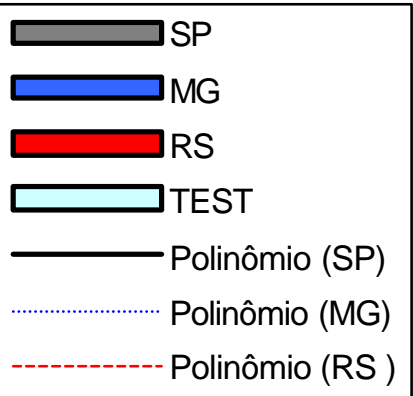

Dias de avaliação

Figura 3 - Freqüência da mortalidade de Spodoptera frugiperda por Bacillus thuringiensis. Médias seguidas da mesma letra não diferem estatisticamente (Tukey $5 \%$ ). Letras minúsculas: análise entre populações em cada dia de avaliação. Letras maiúsculas: análise entre os dias 
Foi verificado que os dados se ajustaram ao modelo proposto e foi obtida uma $\mathrm{CL}_{50}$ de $0,749 \times 10^{8}$ esporos $/ \mathrm{mL}$, com intervalo de confiança de $0,592 \times 10^{8}$ a $0,935 \times 10^{8}$ (95\% de probabilidade). O probit foi calculado pela equação y $=5+(-10,744419)+(-0,1333314) \times \log$ concentração e o probit observado foi obtido pelo programa Raymond.

$\mathrm{Na}$ Figura 4, constata-se os pontos obtidos pelo probit observado, mostrando que os dados têm distribuição homogênea e a inclinação da reta (probit calculado) mostra que a população é heterogênea ("slope" = 1,36 ), ou seja, existem indivíduos mais e menos suscetíveis ao isolado dentro da população testada.

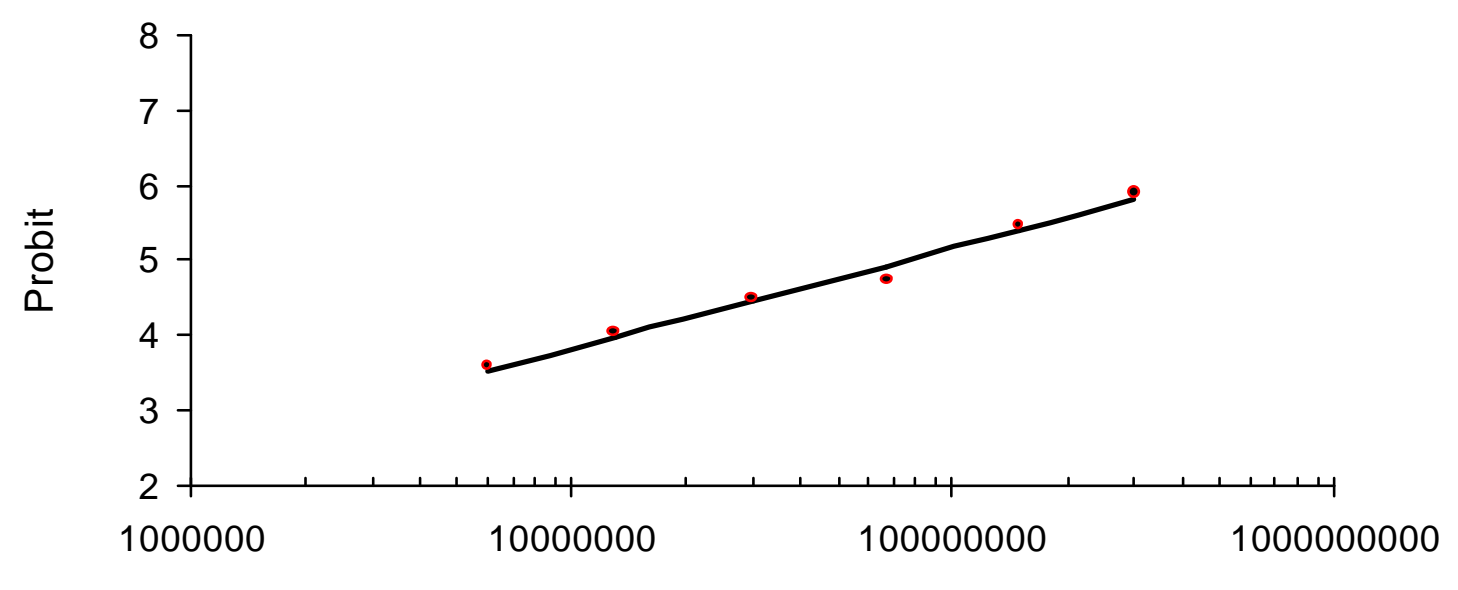

Concentração (log)

Figura 4 - Curva concentração-resposta da mortalidade de lagartas de primeiro ínstar de Spodoptera frugiperda por Bacillus thuringiensis ESALQ 3.7 (pontos: probit observado e reta: probit calculado)

Alguns trabalhos realizados para estimativa da $\mathrm{CL}_{50}$ (Aranda et al.,1996; Bohorova et al., 1997) utilizam, nestes testes, proteínas purificadas de Bt para assegurar que $o$ resultado expresse a atividade somente de 
determinadas toxinas Cry, evitando a influência de outras toxinas, como as VIP's e exotoxinas. No processo de centrifugação seqüencial adotado neste bioensaio considera-se que a eliminação das toxinas indesejáveis, foi feita com o descarte do meio, após a centrifugação. Testes com proteínas purificadas também são utilizados para estudar a eficiência de uma determinada toxina em relação ao inseto-alvo, porém esse não foi o objetivo deste trabalho que foi conduzido utilizando-se a suspensão, provavelmente, contendo mais de uma toxina.

Outro aspecto a ser levado em consideração é a comparação entre resultados. Por exemplo, a falta de padronização dos bioensaios, até 1970, dificultou muito a comparação entre estimativas de $C_{50}$, sendo sugerida a utilização de cepas "padrões", para comparações de eficiência. As primeiras foram adotadas somente a partir de 1970. A primeira, denominada Bt thuringiensis E-61, foi preparada na França, porém posteriormente foi trocada pela Bt kurstaki HD-1, que se mostrou bem mais efetiva que a anterior. Esta padronização permitiu comparações do seu efeito sobre diferentes espéciesalvo, espécies não-alvo, formulações, condições climáticas etc. Do mesmo modo, a falta de padronização dos bioensaios de seleção é um importante obstáculo para a abordagem do assunto, uma vez que comparações de eficiência podem levar a conclusões pouco confiáveis (Glare \& O'Callagham). Alguns esforços têm sido feitos no sentido de minimizar estes problemas como, por exemplo, a formação de grupos interinstitucionais de pesquisa, que utilizam os mesmos métodos de execução e de avaliação de bioensaios, facilitando assim a interpretação dos resultados (Monnerat ${ }^{2}$ ).

${ }^{2}$ MONERRAT, R.. (EMBRAPA. Centro Nacional de Recursos Genéticos e Biotecnologia). Comunicação pessoal, 2003. 


\subsubsection{Efeitos subletais}

Os efeitos subletais dos isolados de $B t$ testados nos quatro primeiros bioensaios, contra lagartas de segundo ínstar de $S$. frugiperda da população de São Paulo, encontram-se na Tabela 6. No primeiro e segundo bioensaios não foi observada diferença significativa entre a testemunha e os tratamentos, tanto para peso de lagartas como de pupas. No bioensaio 3, o tratamento ESALQ 3.7 diferiu estatisticamente dos demais tratamentos, mostrando o efeito subletal deste isolado tanto para lagartas como pupas sobreviventes aos tratamentos. $O$ mesmo foi verificado no último bioensaio para os isolados ESALQ 5.1, 5.2 e 5.2.

A análise de correlação linear ( $r$ ) para cada bioensaio encontra-se na Tabela 7. Para todos os experimentos, menos no segundo, verificou-se um grau de correlação significativo entre o peso de lagarta e pupa, indicando que existe um grau de associação entre os parâmetros avaliados.

Nos bioensaios 1 e 3 somente os isolados ESALQ 1.2 e 3.7 , respectivamente, afetaram, significativamente, o peso de lagarta e pupa fêmea, ao passo que no segundo bioensaio nenhum dos tratamentos diferiu significativamente da testemunha. No último bioensaio, o isolado ESALQ 5.2 causou redução significativa nos parâmetros avaliados. Pode-se afirmar que apesar de existir uma diferença no aproveitamento do alimento contaminado por Bt entre os indivíduos desta população, esta influência foi verificada em apenas quatro dos 43 isolados testados.

Para verificar a relação entre o peso de pupa, oviposição e fecundidade de ovos, foi realizado outro experimento, cujos resultados obtidos constam nas Tabelas 8 e 9 . Foi observada correlação significativa entre os parâmetros avaliados para todos os bioensaios, com exceção do bioensaio 2 . Assim, alguns isolados de Bt são capazes de afetar a fisiologia dos adultos, refletindo na quantidade e qualidade da oviposição. Neste sentido, trabalhando com adultos de $H$. virescens, Abdul-Sattar \& Watson (1982) verificaram que o Bt 
afeta o acasalamento e oviposição, sendo que a fecundidade dos ovos dos adultos sobreviventes foi praticamente nula.

Tabela 6. Efeitos subletais de Bacillus thuringiensis sobre lagartas e pupas fêmeas de segundo ínstar de Spodoptera frugiperda (população de São Paulo)

\begin{tabular}{|c|c|c|c|}
\hline \multicolumn{4}{|c|}{ BIOENSAIO 1} \\
\hline Tratamentos & Lagartas (g) & Tratamentos & Pupas (g) \\
\hline ESALQ 2.3 & $0,3159 \pm 0,017 a$ & Testemunha & $0,2424 \pm 0,002 \mathrm{a}$ \\
\hline ESALQ 2.2 & $0,3094 \pm 0,005 a b$ & ESALQ 2.2 & $0,2255 \pm 0,012 a b$ \\
\hline Testemunha & $0,2917 \pm 0,003 a b c$ & ESALQ 2.3 & $0,2254 \pm 0,009 a b$ \\
\hline ESALQ 1.3 & $0,2758 \pm 0,015 a b c$ & ESALQ 1.1 & $0,2106 \pm 0,005 a b$ \\
\hline ESALQ 1.2 & $0,2668 \pm 0,003 \quad b c$ & ESALQ 1.6 & $0,2071 \pm 0,004 a b$ \\
\hline ESALQ 1.5 & $0,2635 \pm 0,006 \quad b c$ & ESALQ 2.1 & $0,2038 \pm 0,008 a b$ \\
\hline ESALQ 2.1 & $0,2632 \pm 0,006 \quad b c$ & ESALQ 1.5 & $0,2037 \pm 0,007 a b$ \\
\hline ESALQ 1.4 & $0,2524 \pm 0,010 \quad c$ & ESALQ 1.4 & $0,1994 \pm 0,012 b$ \\
\hline ESALQ 1.6 & $0,2506 \pm 0,008 \quad c$ & ESALQ 1.3 & $0,1925 \pm 0,004 \quad b$ \\
\hline ESALQ 1.1 & $0,2480 \pm 0,006$ & ESALQ 1.2 & $0,1913 \pm 0,009 \quad b$ \\
\hline \multicolumn{4}{|c|}{ BIOENSAIO 2} \\
\hline Testemunha & $0,3293 \pm 0,008 a$ & ESALQ 2.9 & $0,2512 \pm 0,013 a$ \\
\hline ESALQ 2.7 & $0,3289 \pm 0,109 a$ & ESALQ 2.8 & $0,2453 \pm 0,011 a$ \\
\hline ESALQ 2.9 & $0,3248 \pm 0,026 a$ & ESALQ 3.3 & $0,2383 \pm 0,008 a$ \\
\hline ESALQ 2.8 & $0,3185 \pm 0,009 a$ & Testemunha & $0,2381 \pm 0,005 a$ \\
\hline ESALQ 2.5 & $0,3160 \pm 0,005 a$ & ESALQ 3.4 & $0,2333 \pm 0,006 a$ \\
\hline ESALQ 2.6 & $0,3150 \pm 0,015 a$ & ESALQ 3.1 & $0,3201 \pm 0,007 a$ \\
\hline ESALQ 2.4 & $0,3067 \pm 0,007 a$ & ESALQ 2.4 & $0,2208 \pm 0,010 a$ \\
\hline ESALQ 3.3 & $0,3038 \pm 0,017 a$ & ESALQ 2.5 & $0,2191 \pm 0,007 a$ \\
\hline ESALQ 3.2 & $0,3019 \pm 0,023 a$ & ESALQ 2.7 & $0,2172 \pm 0,016 a$ \\
\hline ESALQ 3.1 & $0,3015 \pm 0,032 a$ & ESALQ 3.2 & $0,2120 \pm 0,008 a$ \\
\hline ESALQ 3.4 & $0,2945 \pm 0,010 a$ & ESALQ 2.6 & $0,1496 \pm 0,074 a$ \\
\hline
\end{tabular}


Tabela 6. Efeitos subletais de Bacillus thuringiensis sobre lagartas e pupas fêmeas de segundo ínstar de Spodoptera frugiperda (população de São Paulo).

\begin{tabular}{|c|c|c|c|}
\hline \multicolumn{4}{|c|}{ BIOENSAIO 1} \\
\hline Tratamentos & Lagartas (g) & Tratamentos & Pupas (g) \\
\hline \multicolumn{4}{|c|}{ BIOENSAIO 3} \\
\hline Testemunha & $0,2979 \pm 0,017 \mathrm{a}$ & ESALQ 3.12 & $0,2408 \pm 0,177 \mathrm{a}$ \\
\hline ESALQ 3.8 & $0,2858 \pm 0,001 \mathrm{a}$ & ESALQ 3.8 & $0,2318 \pm 0,010 a$ \\
\hline ESALQ 3.12 & $0,2857 \pm 0,004 a$ & ESALQ 3.6 & $0,2315 \pm 0,009 a$ \\
\hline ESALQ 3.6 & $0,2918 \pm 0,014 a$ & ESALQ 3.5 & $0,2298 \pm 0,013 a$ \\
\hline ESALQ 3.5 & $0,2890 \pm 0,005 a$ & Testemunha & $0,2274 \pm 0,006 \mathrm{a}$ \\
\hline ESALQ 3.10 & $0,2877 \pm 0,013 a$ & ESALQ 3.9 & $0,2263 \pm 0,004 a$ \\
\hline ESALQ 3.11 & $0,2819 \pm 0,013 a$ & ESALQ 3.11 & $0,2221 \pm 0,006 \mathrm{a}$ \\
\hline ESALQ 3.13 & $0,2638 \pm 0,002 a$ & ESALQ 3.13 & $0,2186 \pm 0,008 a$ \\
\hline ESALQ 3.9 & $0,2625 \pm 0,008 \mathrm{a}$ & ESALQ 3.10 & $0,2164 \pm 0,016 \mathrm{a}$ \\
\hline ESALQ 4.1 & $0,2610 \pm 0,003 a$ & ESALQ 4.1 & $0,2159 \pm 0,003 a$ \\
\hline ESALQ 3.7 & $0,1734 \pm 0,004 \quad b$ & ESALQ 3.7 & $0,0852 \pm 0,001 \quad b$ \\
\hline \multicolumn{4}{|c|}{ BIOENSAIO 4} \\
\hline ESALQ 4.8 & $0,3261 \pm 0,014 \mathrm{a}$ & ESALQ 4.5 & $0,2338 \pm 0,011 \mathrm{a}$ \\
\hline ESALQ 4.7 & $0,3192 \pm 0,020 \mathrm{a}$ & ESALQ 4.8 & $0,2308 \pm 0,002 a$ \\
\hline ESALQ 4.6 & $0,3129 \pm 0,019 a$ & ESALQ 4.7 & $0,2204 \pm 0,004 a b$ \\
\hline Testemunha & $0,3107 \pm 0,032 \mathrm{a}$ & ESALQ 4.3 & $0,2174 \pm 0,002 a b$ \\
\hline ESALQ 4.5 & $0,3015 \pm 0,004 \mathrm{a}$ & ESALQ 4.9 & $0,2128 \pm 0,008 a b$ \\
\hline ESALQ 4.4 & $0,2860 \pm 0,007 \mathrm{a}$ & Testemunha & $0,2085 \pm 0,015 a b$ \\
\hline ESALQ 4.3 & $0,2810 \pm 0,003 \mathrm{a}$ & ESALQ 4.6 & $0,2073 \pm 0,011 a b$ \\
\hline ESALQ 4.9 & $0,2585 \pm 0,008 a b$ & ESALQ 4.4 & $0,2036 \pm 0,002 a b$ \\
\hline ESALQ 5.1 & $0,2033 \pm 0,013 \quad b$ & ESALQ 5.1 & $0,1902 \pm 0,006 \quad b$ \\
\hline ESALQ 4.2 & $0,1850 \pm 0,003$ & ESALQ 4.2 & $0,1268 \pm 0,004 \quad c$ \\
\hline ESALQ 5.2 & $0,1624 \pm 0,002$ & ESALQ 5.2 & $0,1080 \pm 0,002 \quad c$ \\
\hline
\end{tabular}

Médias seguidas da mesma letra não diferem estatisticamente (Tukey $5 \%$ ). 
Tabela 7. Correlação linear ( $r$ ), entre o peso de lagarta e pupas fêmeas Spodoptera frugiperda sobreviventes a inoculação com Bacillus thuringiensis

\begin{tabular}{ccc}
\hline Bioensaio & Valor $r$ & $\mathrm{P}>\mathrm{t}$ \\
\hline 1 & 0,36 & $0,04748^{*}$ \\
2 & $-0,32$ & 0,07774 \\
3 & 0,70 & $0,00004^{*}$ \\
4 & 0,73 & $0,00001^{*}$ \\
\hline
\end{tabular}

* significativo a $5 \%$ de probabilidade de erro.

Resultados semelhantes aos que constam nas Tabelas 8 e 9 são encontrados na literatura. Salama \& Sharaby (1988) observaram que Bt galleriae afetou a produção e a fecundidade dos ovos. De modo semelhante, Pedersen et al. (1997) e Salama et al. (1981) relataram a redução na oviposição e fertilidade dos ovos para várias espécies de insetos. Porém, diferente dos resultados obtidos neste trabalho, Ramachandram et al. (1993) não observaram efeito prejudicial de Cry1Aa no peso de pupas de C. fumiferana e Hyphantria cunea, sugerindo que esse efeito pode variar de acordo com a toxina testada.

Os estudos dos efeitos subletais dos patógenos pode reformular a concepção de eficiência de controle, uma vez que os insetos sobreviventes aos tratamentos podem ter seu desenvolvimento afetado de tal forma que estes se tornam incapazes de causar dano econômico às plantas. Se este efeito não for considerado pode-se efetuar pulverizações desnecessárias de inseticidas, o que resulta em elevação do custo/produção, maior contaminação ambiental e prejuízos aos inimigos naturais presentes na área. 
Tabela 8. Efeito de Bacillus thuringiensis no peso de pupas, capacidade de oviposição e fecundidade de ovos de Spodoptera frugiperda pertencentes à população de São Paulo

\begin{tabular}{|c|c|c|c|}
\hline Parâmetros & Peso Pupa $^{1}$ & Oviposição** & Fecundidade dos \\
\hline Tratamentos & $(g)^{*}$ & & $\operatorname{ovos}(\%)^{*}$ \\
\hline \multicolumn{4}{|c|}{ BIOENSAIO 1} \\
\hline ESALQ 1.1 & $0,2106 \pm 0,005$ & $139,19 \pm 12,06 a b$ & $52,59 \pm 10,20 a$ \\
\hline ESALQ 1.2 & $0,1913 \pm 0,009$ & $52,40 \pm 18,05 \quad b$ & $07,00 \pm 3,00 b$ \\
\hline ESALQ 1.3 & $0,1925 \pm 0,004$ & $127,40 \pm 29,93 \mathrm{ab}$ & $49,20 \pm 12,37 a$ \\
\hline ESALQ 1.4 & $0,1994 \pm 0,012$ & $142,20 \pm 12,39 a$ & $55,00 \pm 9,15 a$ \\
\hline ESALQ 1.5 & $0,2037 \pm 0,007$ & $107,80 \pm 15,63 a b$ & $48,20 \pm 6,39 a$ \\
\hline ESALQ 1.6 & $0,2071 \pm 0,004$ & $133,80 \pm 12,00 a b$ & $59,00 \pm 4,74 a$ \\
\hline ESALQ 2.1 & $0,2038 \pm 0,008$ & $133,60 \pm 12,79 a$ & $48,40 \pm 11,73 a$ \\
\hline ESALQ 2.2 & $0,2255 \pm 0,012$ & $127,00 \pm 12,88 a b$ & $49,20 \pm 5,08 a$ \\
\hline ESALQ 2.3 & $0,2254 \pm 0,009$ & $154,60 \pm 6,45 a b$ & $57,00 \pm 7,19 a$ \\
\hline Testemunha & $0,2424 \pm 0,002$ & $133,20 \pm 7,93 a b$ & $54,00 \pm 5,22 \mathrm{a}$ \\
\hline \multicolumn{4}{|c|}{ BIOENSAIO 2} \\
\hline ESALQ 2.4 & $0,2208 \pm 0,010$ & $108,20 \pm 13,60 \mathrm{a}$ & $55,00 \pm 12,70 a$ \\
\hline ESALQ 2.5 & $0,2333 \pm 0,006$ & $109,00 \pm 10,85 a$ & $30,79 \pm 4,70 a$ \\
\hline ESALQ 2.6 & $0,3201 \pm 0,007$ & $123,59 \pm 19,44 a$ & $46,20 \pm 7,01 \mathrm{a}$ \\
\hline ESALQ 2.7 & $0,2453 \pm 0,011$ & $117,80 \pm 13,59 a$ & $44,00 \pm 4,70 a$ \\
\hline ESALQ 2.8 & $0,2453 \pm 0,011$ & $114,80 \pm 10,07 \mathrm{a}$ & $48,20 \pm 6,39 a$ \\
\hline ESALQ 2.9 & $0,2512 \pm 0,013$ & $107,80 \pm 6,98 a$ & $39,20 \pm 4,20 a$ \\
\hline ESALQ 3.1 & $0,2120 \pm 0,008$ & $116,80 \pm 24,44 a$ & $47,90 \pm 3,51 a$ \\
\hline ESALQ 3.2 & $0,2120 \pm 0,008$ & $136,40 \pm 5,60 a$ & $50,40 \pm 3,41 a$ \\
\hline ESALQ 3.3 & $0,2191 \pm 0,007$ & $122,80 \pm 18,16 a$ & $47,00 \pm 5,45 a$ \\
\hline ESALQ 3.4 & $0,1496 \pm 0,074$ & $126,80 \pm 9,85 a$ & $53,80 \pm 8,19 a$ \\
\hline Testemunha & $0,2381 \pm 0,005$ & $139,20 \pm 10,52 a$ & $50,00 \pm 4,47 a$ \\
\hline \multicolumn{4}{|c|}{ BIOENSAIO 3} \\
\hline ESALQ 3.5 & $0,2298 \pm 0,013$ & $101,59 \pm 13,23 a b$ & $54,00 \pm 7,14 a$ \\
\hline
\end{tabular}


Tabela 8. Efeito de Bacillus thuringiensis no peso de pupas, capacidade de oviposição e fecundidade de ovos de Spodoptera frugiperda pertencentes à população de São Paulo

\begin{tabular}{|c|c|c|c|}
\hline Parâmetros & Peso Pupa ${ }^{1}$ & Oviposição** & Fecundidade dos \\
\hline Tratamentos & $(g)^{*}$ & & ovos $(\%)^{*}$ \\
\hline ESALQ 3.6 & $0,2315 \pm 0,009$ & $120,60 \pm 09,79 a b$ & $48,60 \pm 7,25 a$ \\
\hline ESALQ 3.7 & $0,0852 \pm 0,001$ & $23,00 \pm 11,64 \quad c$ & $4,00 \pm 1,87 \quad b$ \\
\hline ESALQ 3.8 & $0,2318 \pm 0,010$ & $125,60 \pm 05,98 a b$ & $47,20 \pm 5,76 a$ \\
\hline ESALQ 3.9 & $0,2263 \pm 0,004$ & $138,00 \pm 15,31 a b$ & $51,60 \pm 3,24 a$ \\
\hline ESALQ 3.10 & $0,2263 \pm 0,004$ & $129,60 \pm 13,02 a b$ & $48,60 \pm 3,82 a$ \\
\hline ESALQ 3.11 & $0,2221 \pm 0,006$ & $115,00 \pm 10,77 a b$ & $42,40 \pm 4,63 a$ \\
\hline ESALQ 3.12 & $0,2408 \pm 0,177$ & $96,59 \pm 19,34 \quad b c$ & $27,80 \pm 6,12 a b$ \\
\hline ESALQ 3.13 & $0,2186 \pm 0,008$ & $156,40 \pm 07,66 a$ & $43,40 \pm 14,85 a$ \\
\hline ESALQ 4.1 & $0,2159 \pm 0,003$ & $123,20 \pm 09,04 a b$ & $49,20 \pm 4,04 a$ \\
\hline Testemunha & $0,2274 \pm 0,006$ & $137,20 \pm 04,69 a b$ & $52,20 \pm 7,17 a$ \\
\hline \multicolumn{4}{|c|}{ BIOENSAIO 4} \\
\hline ESALQ 4.2 & $0,1268 \pm 0,004$ & $69,80 \pm 10,08 a b$ & $27,60 \pm 4,91 \mathrm{ab}$ \\
\hline ESALQ 4.3 & $0,2174 \pm 0,002$ & $121,59 \pm 21,02 a$ & $59,60 \pm 3,55 a$ \\
\hline ESALQ 4.4 & $0,2036 \pm 0,002$ & $127,40 \pm 29,93 a$ & $40,00 \pm 7,04 a b$ \\
\hline ESALQ 4.5 & $0,2338 \pm 0,011$ & $133,00 \pm 10,60 a$ & $40,60 \pm 5,50 a b$ \\
\hline ESALQ 4.6 & $0,2204 \pm 0,004$ & $122,80 \pm 07,74 a$ & $49,20 \pm 6,01 \mathrm{ab}$ \\
\hline ESALQ 4.7 & $0,2204 \pm 0,004$ & $129,80 \pm 13,79 a$ & $45,20 \pm 4,50 a b$ \\
\hline ESALQ 4.8 & $0,2308 \pm 0,002$ & $126,00 \pm 05,18 \mathrm{a}$ & $44,60 \pm 3,85 a b$ \\
\hline ESALQ 4.9 & $0,2128 \pm 0,008$ & $138,00 \pm 11,83 a$ & $46,20 \pm 4,21 a b$ \\
\hline ESALQ 5.1 & $0,1902 \pm 0,006$ & $112,60 \pm 13,68 a b$ & $47,80 \pm 6,03 a b$ \\
\hline ESALQ 5.2 & $0,1080 \pm 0,002$ & $46,00 \pm 19,15 \quad b$ & $22,80 \pm 6,97 \quad b$ \\
\hline Testemunha & $0,2085 \pm 0,015$ & $127,19 \pm 06,00 \mathrm{a}$ & $48,40 \pm 7,60 a b$ \\
\hline
\end{tabular}

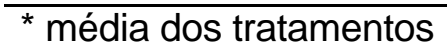

** número de ovos no segundo dia após a formação do casal.

${ }^{1}$ Dados da Tabela 6. 
Tabela 9. Análise da correlação linear ( $r$ ), entre o peso de pupas fêmeas, oviposição e fecundidade de ovos de Spodoptera frugiperda sobreviventes à inoculação com Bacillus thuringiensis (população de São Paulo)

\begin{tabular}{|c|c|c|}
\hline Bioensaio / parâmetros avaliados & Valor $r$ & $P>t$ \\
\hline \multicolumn{3}{|l|}{1} \\
\hline Peso pupas fêmeas $x$ oviposição & 0,18 & $0,0002^{*}$ \\
\hline Peso pupas fêmeas $x$ fecundidade de ovos & 0,37 & $0,0067^{*}$ \\
\hline Oviposição $x$ fecundidade de ovos & 0,49 & $0,0004^{*}$ \\
\hline \multicolumn{3}{|l|}{2} \\
\hline Peso pupas fêmeas $x$ oviposição & $-0,06$ & 0,6527 \\
\hline Peso pupas fêmeas $x$ fecundidade de ovos & -0.06 & 0,6496 \\
\hline Oviposição x fecundidade de ovos & -0.13 & 0.6721 \\
\hline \multicolumn{3}{|l|}{3} \\
\hline Peso pupas fêmeas $x$ oviposição & 0,52 & $0,0001^{*}$ \\
\hline Peso pupas fêmeas $x$ fecundidade de ovos & 0,54 & $0,0001^{*}$ \\
\hline $\begin{array}{l}\text { Oviposição } \times \text { fecundidade de ovos } \\
4\end{array}$ & 0,55 & $0,0001^{*}$ \\
\hline Peso pupas fêmeas $x$ oviposição & 0,37 & $0,0053^{*}$ \\
\hline Peso pupas fêmeas $x$ fecundidade de ovos & 0,26 & $0,0454^{*}$ \\
\hline Oviposição $\mathrm{x}$ fecundidade de ovos & 0.47 & $0,0005^{\star}$ \\
\hline
\end{tabular}

* significativo a $5 \%$ de probabilidade de erro.

\subsubsection{Caracterização molecular}

Dentre os 83 isolados testados, 60 (72\%) amplificaram fragmentos de DNA homólogos aos genes cry1 independente da intensidade das bandas obtidas (Figura 5). Entre os isolados que amplificaram estes fragmentos está o ESALQ 3.7, que foi mais ativo para as lagartas de $S$. frugiperda provenientes do Estado de São Paulo. Para a realização do PCR com os iniciadores específicos: cry1(a,b,c), cry1B, cry1C, cry1D, cry1F e cry1E (Figura 6) foram escolhidos alguns isolados que causaram mortalidade igual ou superior a $40 \%$, em qualquer uma das populações testadas (Tabela 5) 


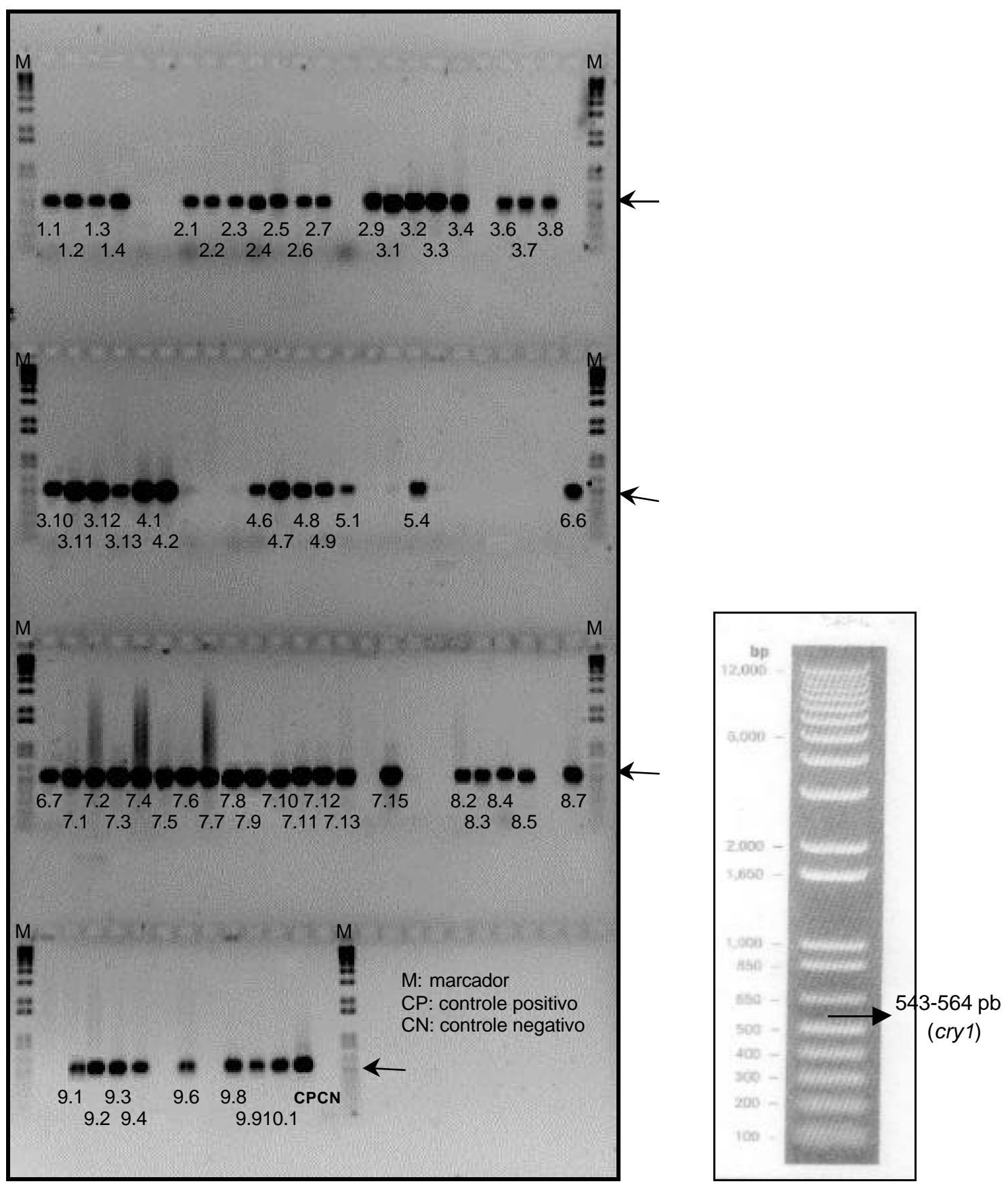

Figura 5 - Eletroforograma de material genético dos isolados de Bacillus thuringiensis amplificados com a utilização dos iniciadores Gralcry1. CP: controle positivo (Bacillus thuringiensis HD-1), CN: água e reação; M: marcador molecular (1Kb plus). As setas indicam o tamanho esperado das bandas 


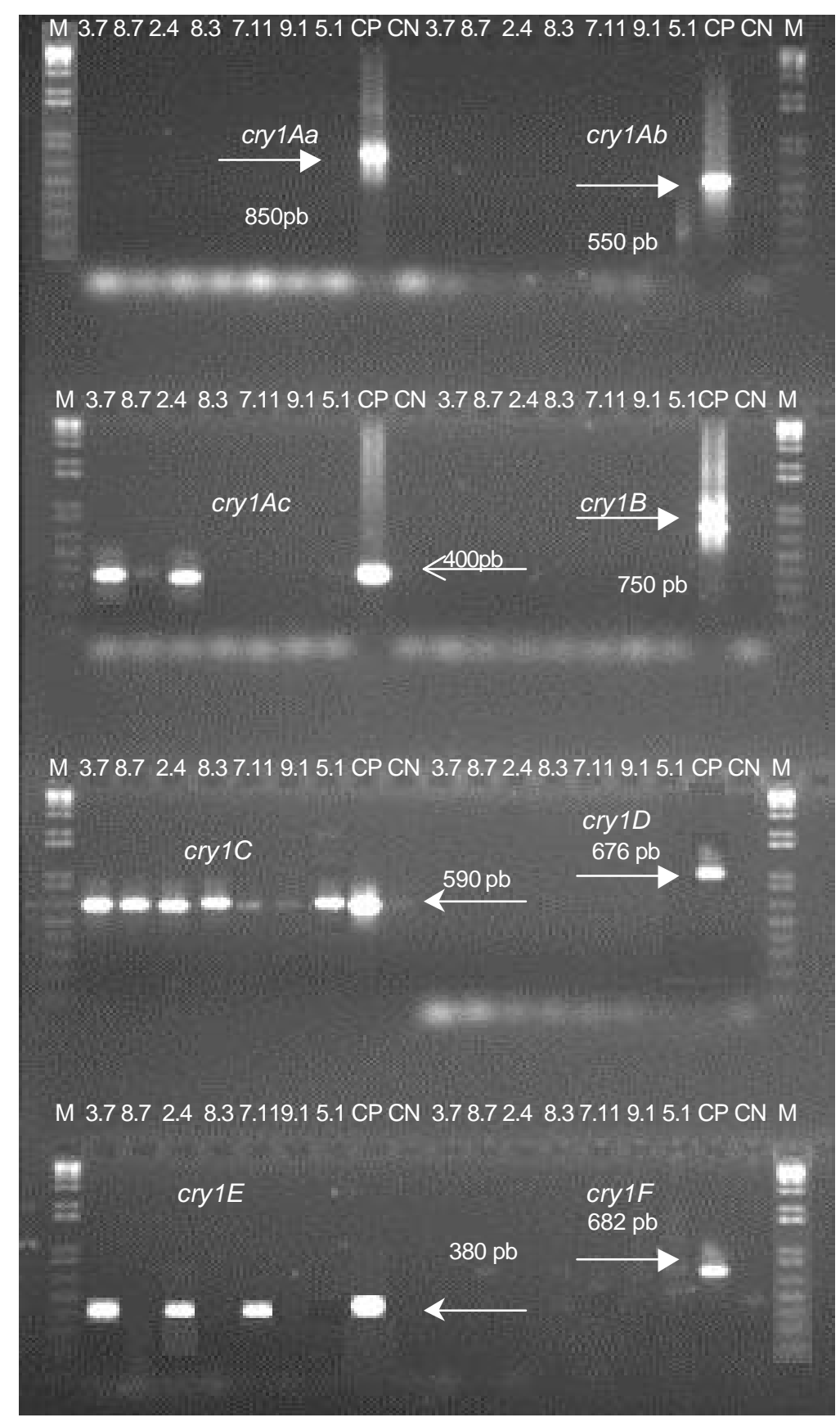

Figura 6 - Eletroforograma de material genético dos isolados de Bacillus thuringiensis amplificados com a utilização dos iniciadores cry1 $(a, b, c)$, cry1B, cry1C, cry1D, cry1F e cry1E. CP: controle positivo, CN: água e reação; M: marcador molecular (1Kb plus). As setas indicam o tamanho esperado das bandas 
Nenhum dos isolados testados (ESALQ 3.7, 8.7, 2.4, 8.3 7.11, 9.1 e 5.1) amplificou fragmentos de DNA correspondentes aos genes cry1Aa, cry $1 A b$, cry1B, cry1D e cry1F. Os isolados ESALQ 3.7 e ESALQ 2.4 amplificaram os genes cry $1 A c$, cry $1 C$ e cry $1 E$ e o isolado ESALQ 8.7 amplificou somente cry1C (Figura 6). Esses três isolados foram aqueles que apresentaram maior atividade para lagartas pertencentes à população de São Paulo: 86,6\%, 46,66\% e $57,76 \%$, respectivamente. Relacionando os resultados obtidos para esses três isolados, pode-se sugerir que a atividade da Cry1C $(57,76 \%)$, no isolado ESALQ 8.7, é incrementada pela presença de Cry1Ac e Cry1E no isolado ESALQ 3.7 (86,6\%), porém o mesmo não foi constatado para o isolado ESALQ $2.4(46,66 \%)$. De um modo geral, a diferença entre a atividade dos isolados pode ser devida à presença de outras toxinas, além daquelas que foram constatadas e, que podem interagir de forma positiva ou negativa com Cry $1 \mathrm{Ac}$, Cry1C e Cry1E. Uma destas toxinas poderia ser a Cry1l, que conforme Fatoretto (2002), têm atividade inseticida para a lagarta-do-cartucho.

De acordo com Fatorretto (2002) e Loguercio et al (2001), a toxina Cry1E em combinações com outras toxinas como, por exemplo, Cry1Ac, tem elevado potencial de controle para $S$. frugiperda. Outros trabalhos como os realizados por Aranda et al. (1996) e Bravo et al. (1998) ressaltam a eficiência de Cry1C no controle da lagarta-do-cartucho. Os mesmos autores enfatizam o potencial de Cry1D para o manejo de $S$. frugiperda, porém esta toxina não foi encontrada nos isolados analisados. Contrário aos dados verificados neste trabalho, Luo et al. (1999) constataram que Cry1C foi pouco ativa para S. frugiperda. Esses dados indicam que a atividade de uma determinada toxina pode variar de acordo com a origem geográfica dos insetos testados. Estudos posteriores devem ser realizados para uma abordagem mais precisa da eficiência de toxinas Cry para diferentes populações da lagarta-do-cartucho. Tais trabalhos podem ser fundamentais na decisão de uso de táticas de controle visando o manejo de $S$. frugiperda, assim como de outras pragas importantes. 


\subsection{Conclusões}

Ocorre variação significativa na atividade de alguns isolados de $B t$ para cada população de $S$. frugiperda, bem como entre as mesmas.

O isolado ESALQ 3.7 é o mais promissor para ser utilizado no controle da lagarta-do-cartucho, no Estado de São Paulo.

Alguns isolados de Bt afetam o peso de lagartas, peso de pupas fêmeas, oviposição e fecundidade dos ovos de indivíduos sobreviventes à inoculação.

Os genes cry1 ocorrem na maioria dos isolados de Bt testados para o controle da lagarta-do-cartucho.

Os isolados ESALQ 3.7 e ESALQ 2.4 possuem o maior número de genes da classe cry1. 


\section{PERSISTÊNCIA E ATIVIDADE DE Bacillus thuringiensis PARA Spodoptera frugiperda EM CASA-DE-VEGETAÇÃO E CAMPO}

\section{Resumo}

Estudou-se em casa-de-vegetação e campo a persistência de $B t$ utilizando-se, inicialmente, três produtos a base desse patógeno e, posteriormente, avaliou-se a persistência do isolado ESALQ 3.7 para o controle de Spodoptera frugiperda. O Bt foi aplicado em campo (Dipel, Ecotech PRO e Bac-Control PM) e em casa-de-vegetação e campo (ESALQ 3.7) em plantas de milho. A persistência dos esporos e sua meia vida $(\pi)$ foram avaliadas coletando-se 2 discos foliares de plantas escolhidas ao acaso, 3, 8, 27, 32, 51, 56 e 72 horas após a pulverização. Para relacionar a persistência com a atividade do isolados ESALQ 3.7 para $S$. frugiperda as plantas foram, artificialmente, infestadas e o dano foi avaliado 7 e 14 dias após a aplicação, utilizando-se escala de notas de 0 a 5 . A persistência do Dipel foi superior a dos outros 2 produtos, até 27 horas depois da aplicação dos tratamentos (65.772 esporos $/ \mathrm{mL}$ ), porém sua meia vida ( $\pi=17,54$ horas) foi inferior. O estudo da persistência do isolado ESALQ 3.7 de $B t$ foi prejudicado por fatores bióticos e abióticos, tanto em campo como em casa-de-vegetação, comprometendo a validação dos resultados. Não foi verificada diferença estatística significativa nas notas da escala de dano causado pela lagarta-do-cartucho na testemunha e tratamento (ESALQ 3.7) 


\section{Summary}

The persistence of $B t$ has been evaluated at greenhouse and field conditions using three different $B t$ based products and the isolate ESALQ 3.7. After, it has also been evaluated the activity of ESALQ 3.7 to control Spodoptera frugiperda. Bt was sprayed in the field (Dipel, Ecotech PRO and Bac-controle PM) and at greenhouse and in the field (ESALQ 3.7) on maize plants. The spore persistence and its half-life $(\pi)$ were evaluated collecting ramdomly 2 leaves samples 3, 8, 27, 32, 51, 56 and 72 hours after spraying. To correlate the ESALQ 3.7 persistence and the patogenicity to $S$. frugiperda there have been carried out bioassays at greenhouse and field conditions using plants artificially infested with the fall armyworm. The damage was evaluated 7 and 14 days after infestation using a visual scale of damages that varied from 0 to 5 . Dipel persistence (65.772 spores. $\mathrm{mL}^{-1}$ ) was higher than the others two products tested until 27 hours after pulverization, however its half-life $(\pi=17.54$ hours) was lower than the others treatments. The persistence study of the ESALQ 3.7 isolate was prejudiced by biotic and abiotic factors at greenhouse and field conditions. There was no statistical difference in the damage level caused by fall armyworm among the treatments (ESALQ 3.7).

\subsection{Introdução}

Apesar dos importantes avanços na formulação de biopesticidas, que propiciaram incrementos relevantes, tanto em termos de persistência no ambiente como eficiência contra insetos praga, a reduzida persistência das formulações de entomopatógenos sempre foi uma das principais causas de sua baixa eficiência (Pinnock et. al. 1971). Em relação aos produtos formulados com Bacillus thuringiensis $(B t)$, a radiação ultravioleta é um dos fatores que reduz significativamente sua persistência e, conseqüentemente, sua eficiência em 
campo. Neste sentido, embora alguns estudos sobre a persistência de $B t$ tenham sido realizados (Cantwell \& Franklin 1966, Raun et al., 1966; Pinnock et al., 1971; 1974; 1975), alguns pesquisadores utilizaram lâmpadas ultravioletas com comprimentos de onda diferentes da radiação solar em seus experimentos (Griego \& Spence 1978; Yamvrias 1962). Além disso, nenhum deles quantificou essa inativação em casa-de-vegetação e/ou campo. A persistência e a eficiência fornecem indícios importantes sobre o potencial deste microrganismo em afetar organismos não-alvo.

Este estudo foi realizado para quantificar a persistência de $B t$ em casa-de-vegetação e campo, pelo número de esporos viáveis e pela estimativa da meia vida dos esporos viáveis $(\pi)$. A meia vida é usualmente definida como o período de tempo necessário para a desintegração da metade de uma determinada substância. Além disso, procurou-se relacionar os resultados obtidos com uma escala de dano para a lagarta-do-cartucho no milho, para verificar o efeito do isolado ESALQ 3.7, selecionado em estudos laboratoriais como o mais promissor para o controle dessa praga (capítulo 4).

\subsection{Material e Métodos}

\subsubsection{Bioensaio preliminar}

Para testar a adequação do método a ser empregado nos experimentos, inicialmente foi realizado um teste em campo com três formulações de Bt. Dipel e Ecotech PRO (suspensão concentrada) e BacControl PM (pó molhável) para avaliação da sua persistência em campo. Foram utilizadas três concentrações para cada produto: recomendada, metade e dobro da recomendada, com 3 repetições para cada tratamento. Antes da aplicação, a viabilidade dos produtos (número de esporos viáveis) foi determinada em laboratório de acordo com Alves \& Moraes (1998): 560 milhões/mL (Dipel), 145 milhões/mL (Ecotech Pro) e 196 milhões/mL (Bac-Control). 
O experimento foi conduzido na área experimental do Departamento de Entomologia, Fitopatologia e Zoologia Agrícola (ESALQ/USP). As condições climáticas do local durante o período experimental, expressas em valores médios foram: temperatura de $19,5{ }^{\circ} \mathrm{C}, 82,2 \%$ de umidade relativa do ar, velocidade do vento de 1,1 metros/segundo, ausência de chuva e radiação global de $14,62 \mathrm{MJ} / \mathrm{m}^{2}$. Os dados foram obtidos junto à Estação Metereológica Automática ( $22^{\circ} 42^{\prime} 30^{\prime \prime} \mathrm{S}, 47^{\circ} 38^{\prime} 00^{\prime \prime} \mathrm{O}$ e 546 metros de altitude), pertencente ao Departamento de Física e Metereologia da ESALQ/USP.

O plantio do milho (Zea mays) (híbrido AG 1051) foi realizado na área experimental do Setor de Entomologia, em 19/08/2002. No estágio de plântula, foi conduzido o desbaste de modo a manter uma população de cerca de 60.000 plantas por hectare. Sempre que necessário, a área foi irrigada para permitir o normal desenvolvimento da cultura.

As suspensões foram aplicadas em 45 plantas de milho, entre os estágios de desenvolvimento v3 e v4 (Fancelli, 1990), utilizando-se um pulverizador costal de $\mathrm{CO}_{2}$, equipado com bico tipo leque 8004 , em jato dirigido sobre a linha de plantas, com volume de calda de $300 \mathrm{~L} /$ ha, à pressão de 32 $\mathrm{Lb} / \mathrm{pol}^{2}$.

Em cada tratamento, três plantas foram escolhidas ao acaso, e seis folhas da parte superior foram selecionadas (sem sombreamento e com inclinação semelhante). Três destas folhas foram destacadas da planta e transferidas para B.O.D. (24 horas de escotofase, $25 \pm 0,5{ }^{\circ} \mathrm{C}$ e $70 \pm 10 \%$ umidade relativa) e outras três permaneceram na planta, ou seja, ausência e presença de radiação ultravioleta, respectivamente. Em cada folha foram feitas avaliações 3, 8, 27, 32, 51, 56 e 72 horas após a pulverização, removendo-se 2 discos foliares com $1 \mathrm{~cm}$ de diâmetro, em cada folha da testemunha (ausência de ultravioleta) e do tratamento (presença de ultravioleta) (Figura 1). A remoção dos discos foliares foi feita com auxílio de um vazador e a extremidade da folha destacada foi envolvida por algodão umedecido com água para manter a sua turgidez. 

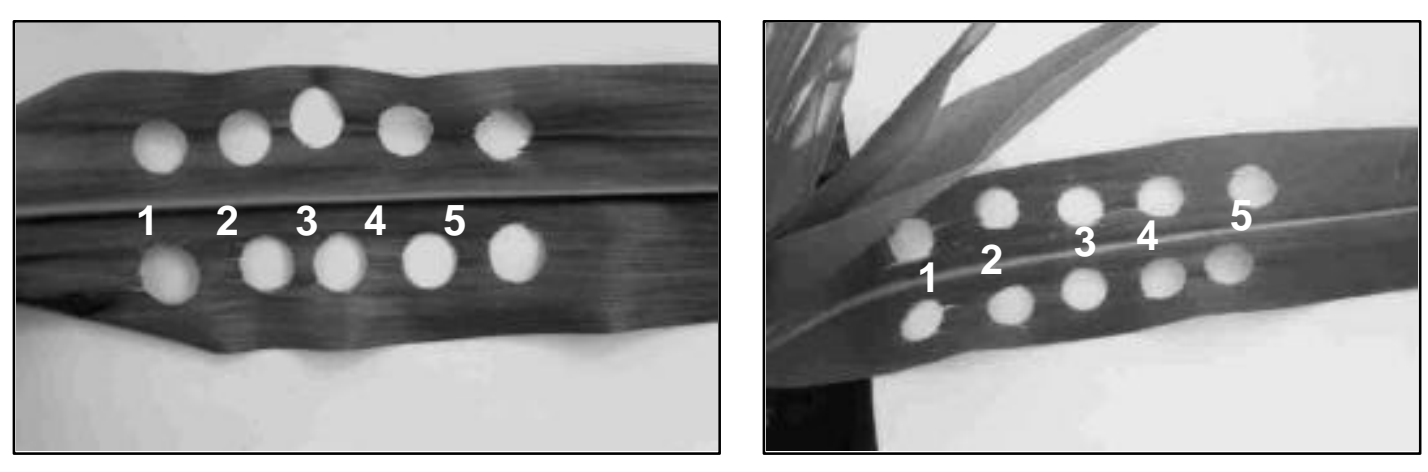

Figura 1 - Amostragem dos discos foliares nas cinco primeiras avaliações; à esquerda: folha no escuro (ausência de ultravioleta) e à direita: folha na planta (presença de ultravioleta)

Cada amostra (disco foliar) foi transferida para um tubo de vidro contendo $10 \mathrm{~mL}$ de água destilada e agitada durante um minuto. Após, $1 \mathrm{~mL}$ foi retirado do tubo e submetido a choque térmico $\left(80^{\circ} \mathrm{C}\right.$ e $-10^{\circ} \mathrm{C}, 10$ e 3 minutos, respectivamente), para eliminar os contaminantes e microrganismos indesejáveis. Posteriormente, $5 \mu \mathrm{l}$ foram aplicados em 5 pontos de uma placa de Petri, contendo meio de cultura $(0,5 \%$ extrato de levedura; $0,1 \%$ de triptona; $0,17 \mathrm{M} \mathrm{NaCl}$ e $0,15 \%$ de ágar bacteriológico) apropriado para o crescimento bacteriano. As placas foram incubadas em B.O.D. e a avaliação do crescimento bacteriano foi realizada 24 ou 48 horas após a incubação, dependendo do grau de nitidez na avaliação das colônias. No total, 756 placas de Petri foram utilizadas em todas as amostragens e a determinação do número de esporos viáveis foi feita de acordo com Alves e Moraes (1998).

Para análise dos dados um modelo exponencial foi utilizado: $Y_{i}=a * \exp \left(b * t_{i}\right) * e_{i}$, onde: $Y_{i}=$ número de esporos viáveis; $a=$ média de esporos viáveis imediatamente após a aplicação da formulação; $b=$ taxa de inativação dos esporos; $t=$ tempo após a aplicação (horas); $e_{i}=$ erro experimental e $\mathrm{i}=$ $1,2 \ldots$... O modelos exponencial foi submetido a anamorfose logarítmica, e o 
método de máxima semelhança foi utilizado para a estimativa dos parâmetros. Devido a esta transformação, as contagens de esporos viáveis iguais a zero foram substituídas por 0,5/número de repetições. Também as contagens iguais observadas na mesma avaliação foram consideradas um ponto, para facilitar a visualização gráfica. Os dados do número de esporos viáveis foram submetidos à análise de variância (ANOVA) e as médias foram comparadas pelo Teste de Tukey a $5 \%$. A determinação da meia vida dos esporos viáveis é um parâmetro usualmente empregado na seleção de biopesticidas e de acordo com Pinnock et al. (1971) é expresso por $\pi=\ln (0,5) /$ - b (horas). Para a comparação dos $\pi$ foi utilizado o método de sobreposição dos intervalos de confiança $(P=0,05)$.

\subsubsection{Bioensaio em casa-de-vegetação}

Neste experimento foi utilizado o mesmo método de avaliação da viabilidade de $B t$ do ensaio preliminar, sendo utilizado nesse caso $\mathrm{o}$ isolado ESALQ 3.7, selecionado nos bioensaios como o mais promissor para $S$. frugiperda. Além da persistência, também foi feita avaliação dos danos causados pelos insetos, conforme a escala abaixo (Figura 2). A semeadura do milho (híbrido AG 1051) foi realizada manualmente em 21/07/2003, em vasos plásticos $(30 \times 30 \mathrm{~cm})$, sendo mantidas três plantas em cada recipiente. Quando elas atingiram o estágio $\mathrm{v} 3 \mathrm{e} v 4$ foram pulverizadas com uma suspensão contendo $3 \mathrm{x}$ $10^{8}$ esporos $/ \mathrm{mL}$, conforme item 5.2.1.

Para a infestação uniforme de lagartas, foi utilizada uma "bazuca" (Wiseman et al., 1980), com a qual 10 lagartas recém-eclodidas foram misturadas com sabugo de milho seco moído e transferidas para as plantas. Foram utilizadas 40 plantas, distribuídas em 3 repetições e testemunha.

Durante a realização deste bioensaio as plantas ficaram dentro de casa-de-vegetação com paredes de filme plástico (modelo Van der Hoeven), com temperatura em torno de $25 \pm 2{ }^{\circ} \mathrm{C}$ e 70 a $80 \%$ de umidade relativa. 
Para avaliação da viabilidade do isolado ESALQ 3.7 foi utilizado o mesmo método do item 5.2.1. A análise visual da escala de dano foi feita 7 e 14 dias após a aplicação dos tratamentos (Figura 2).

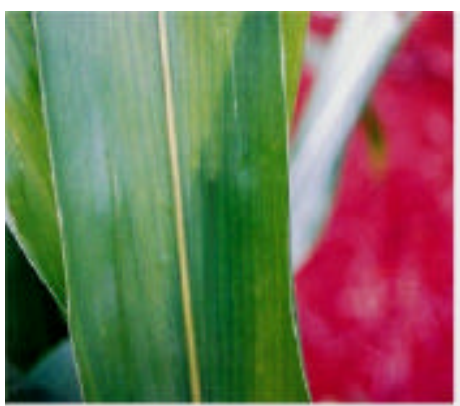

Sem Injuria

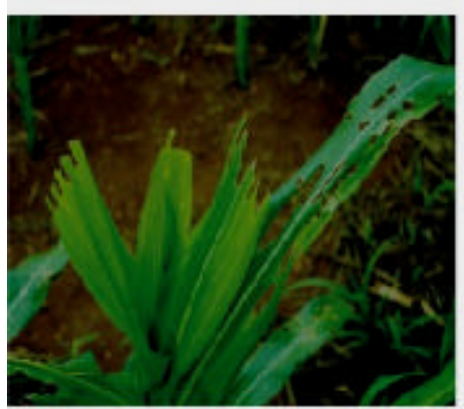

Inyurta 3

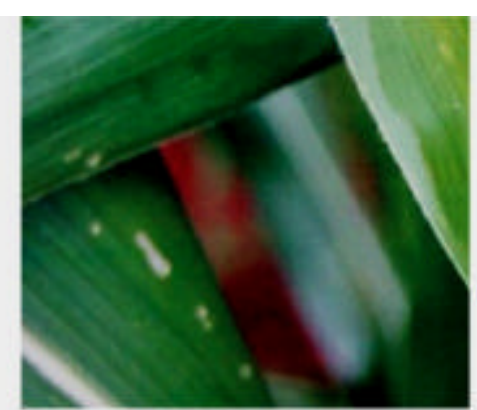

Injữna ?

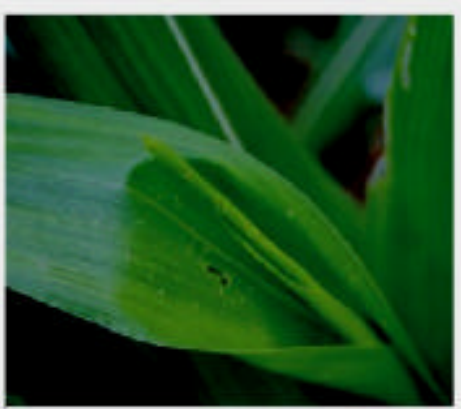

Injuม 4

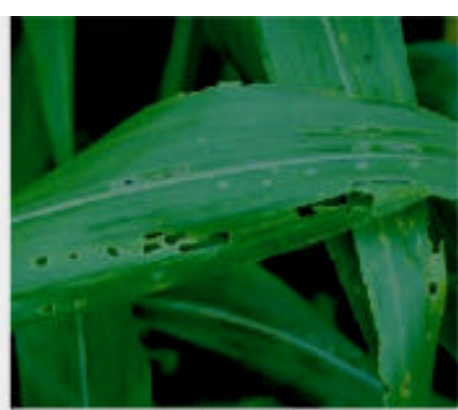

Ingre?

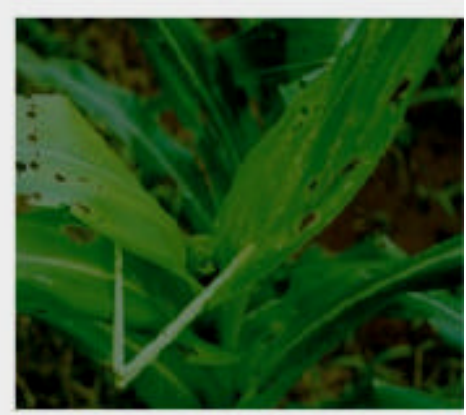

Injuria 5

Figura 2 - Escala de notas de injúria provocada por Spodoptera frugiperda em milho. (Fotos: Vinícius de Carvalho). Sem injúria: folha sem dano; Injúria 1: Folha raspada; Injúria 2: folha perfurada; Injúria 3: folhas rasgadas; Injúria 4: cartucho destruído e Injúria 5: folhas rasgadas e cartucho destruído

Os resultados dos bioensaios foram submetidos à análise de variância, e quando evidenciada diferença significativa entre as médias ao nível de $5 \%$ de probabilidade de erro, efetuou-se a complementação da análise por meio da comparação entre médias pelo teste de Tukey a $5 \%$. 


\subsubsection{Bioensaio em campo}

Este bioensaio foi conduzido e avaliado de modo semelhante aos bioensaios anteriores (5.2.1 e 5.2.2). Foram utilizadas cinco parcelas como tratamento (isolados ESALQ 3.7) e uma como testemunha (água). Cada parcela foi composta por cinco linhas de plantas, com $4 \mathrm{~m}$ de comprimento e $0,9 \mathrm{~m}$ de espaçamento entre linhas. As duas linhas externas e um metro em cada extremidade da parcela foi deixado como bordadura.

O plantio do milho ( $Z$. mays) (híbrido $A G$ 1051) foi realizado na área experimental do Setor de Entomologia, em 23/07/2003. No estágio de plântula, foi conduzido o desbaste de modo a manter uma população de cerca de 60.000 plantas por hectare. Sempre que necessário, a área foi irrigada para permitir o normal desenvolvimento da cultura.

\subsection{Resultados e Discussão}

\subsubsection{Bioensaio preliminar}

Verificou-se que a persistência do Dipel foi superior a dos outros 2 formulados, até 27 horas após a aplicação (65.772 esporos $/ \mathrm{mL}$ ), sendo que após este período não foi verificada diferença estatística significativa entre os tratamentos. A quantidade de esporos aplicados não influenciou a persistência pois a dose recomendada foi considerada como co-variável $(P \leq 0,05)$ (Figura 3). Entretanto, a meia vida do Dipel (17,54 horas) foi inferior aos dos outros dois produtos (Tabela 1). A mesma tabela mostra as diferenças de $\pi$ entre o escuro (ausência de ultravioleta) e campo (presença de ultravioleta), o que mostra claramente 0 efeito desta radiação sobre a persistência dos produtos formulados com Bt. 
Tabela 1. Estimativa da meia-vida $(\pi)$ (horas) e intervalos de confiança $(P=0,05)$ de produtos à base de Bacillus thuringiensis na Câmara Climatizada (ausência de ultravioleta) e em campo (presença de ultravioleta)*

\begin{tabular}{ccccccc}
\hline Produtos & \multicolumn{2}{c}{ Campo } & \multicolumn{3}{c}{ Câmara Climatizada } \\
\hline Ecotech & 24,8 & $(21,68 ; 29,34)$ A & b & 43,32 & $(32,75 ; 65,43)$ A & a \\
Bac-control & 25,76 & $(22,24 ; 30,25)$ A & b & 47,22 & $(31,58 ; 94,34)$ A & a \\
Dipel & $17,54(13,41 ; 19,84)$ & B b & 28,87 & $(22,16 ; 31,12)$ & B a
\end{tabular}

${ }^{*}$ Médias seguidas pela mesma letra maiúsculas nas linhas e minúsculas nas colunas, não diferem entre si pelo teste de Tukey a 5\% de probabilidade de erro.

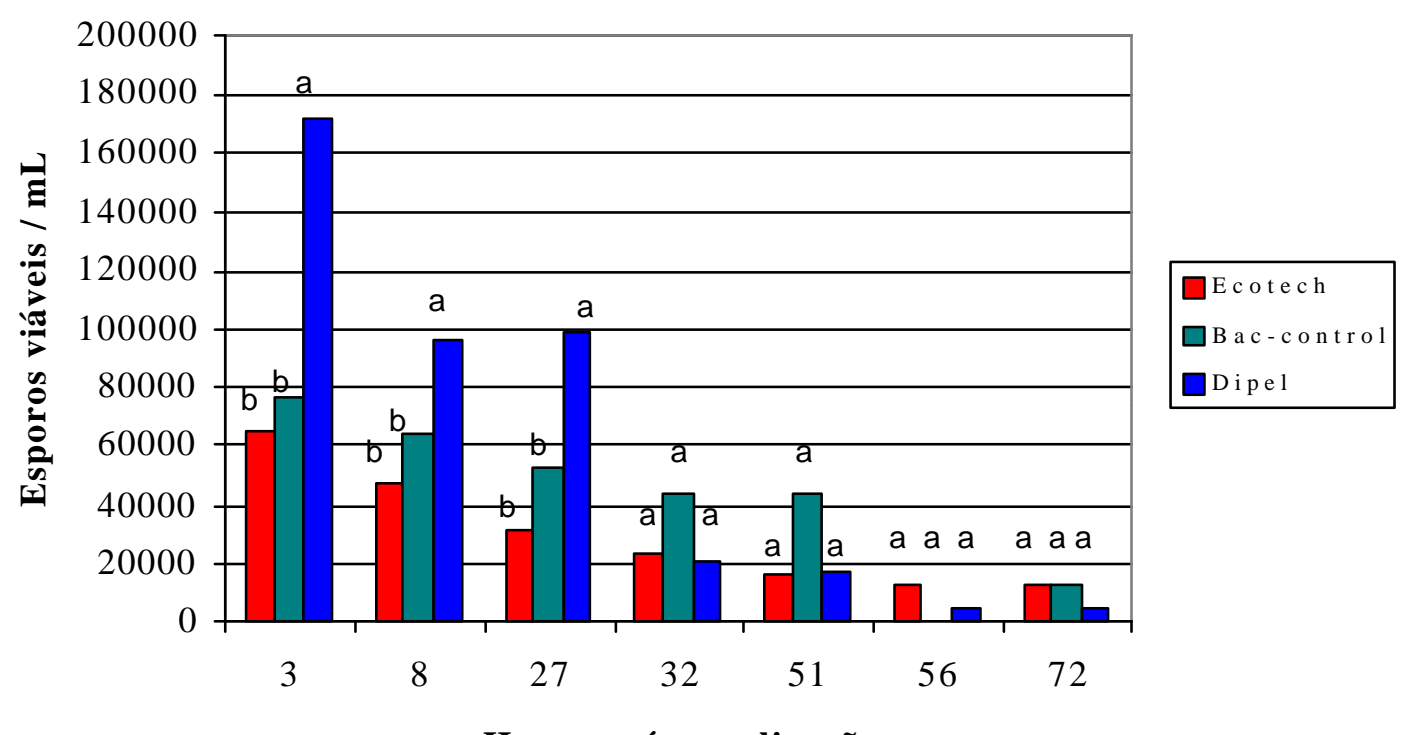

Figura 3 - Viabilidade de esporos de Bacillus thuringiensis em campo. Média de três concentrações $(P \leq 0,05)$

Por apresentar o maior número de esporos viáveis até 27 horas após a aplicação dos tratamentos, o Dipel provavelmente possui características intrínsecas que proporcionam a este produto uma alta viabilidade inicial, porém com uma queda significativa logo em seguida. Por outro lado, Ecotech PRO 
(suspensão concentrada) e Bac-Control PM (pó-molhável) apresentam um menor número de esporos viáveis ao longo do período de avaliação, porém meia-vida superior ao Dipel. Assim como foi salientado para o Dipel, provavelmente esses dois produtos possuem características que auxiliam a prolongar sua persistência, apesar do baixo número de esporos viáveis. Como o número de cristais foi praticamente o mesmo para todos os produtos, a diferença no comportamento se deve, provavelmente, a algum elemento da formulação. Pode-se afirmar que, neste estudo, a persistência depende mais do produto em si do que do grupo de formulação a que ele pertence.

Embora os dados dos três produtos tenham se ajustado ao modelo proposto, Bac-Control apresentou resultados estatísticos melhores que Ecotech e Dipel, pois estes dois últimos mostram um melhor agrupamento dos dados em torno da reta obtida (Figura 4). A fim de se obter um melhor ajuste dos dados, em estudos posteriores, poderia-se utilizar o modelo segmentado nas estimativas da persistência do $B t$.

Em relação a outros fatores que podem afetar a persistência, a poluição do ar pode ter influência nos resultados, conforme foi verificado por Pinnock et al. (1971) em trabalho experimental realizado em Monterrey (Califórnia, EUA). Porém, no referido estudo a área que foi utilizada é cercada por áreas verdes, sem indústrias com grande potencial poluente nas proximidades.

Do ponto de vista prático, Batista Filho et al. (1998) afirmaram que a persistência de formulações de Bt é um dos fatores chave de seu sucesso. Esta importância aumenta quando o comportamento da praga apresenta um certo nível de complexidade que foge do usual, ou seja, reduzida exposição ao produto. Este é o caso do bicho-furão (Ecdytolopha aurantiana), uma das principais pragas de citros no Brasil. Após a eclosão, a lagarta permanece um curto período de tempo na superfície do fruto (4 horas) e em seguida penetra e permanece dentro do fruto o restante do período larval (Gallo et al., 2002). Desta forma, o tempo de exposição ao produto é reduzido, sendo necessário o acompanhamento do ciclo desta praga, para viabilizar a adoção de produtos à base de $B t$. 
A

BAC-CONTROL -Campo

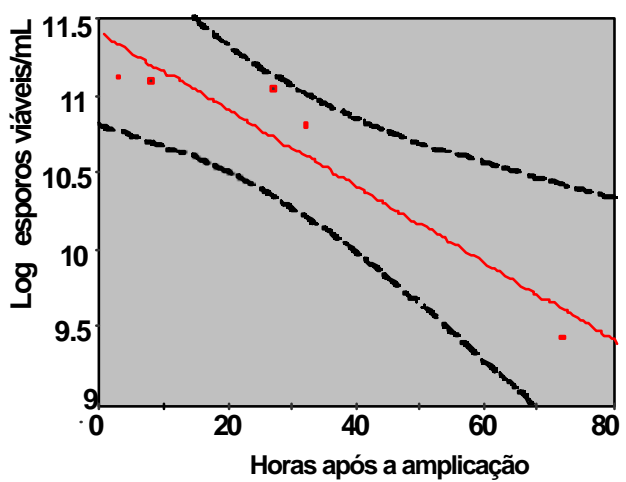

ECOTECH- Campo

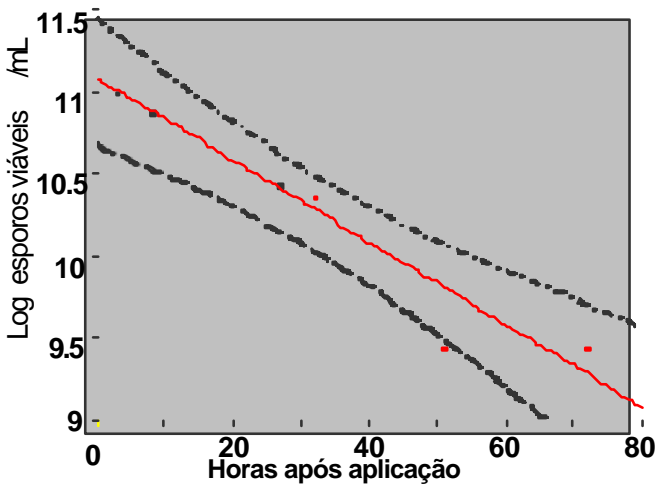

Diper Campo

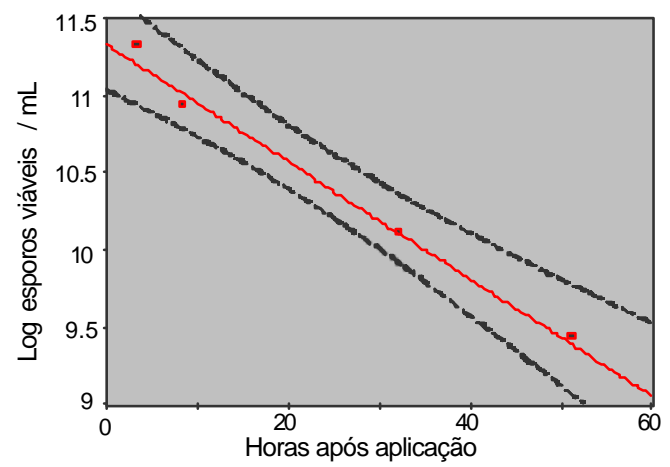

B

BAC-CONTROL - Escuro

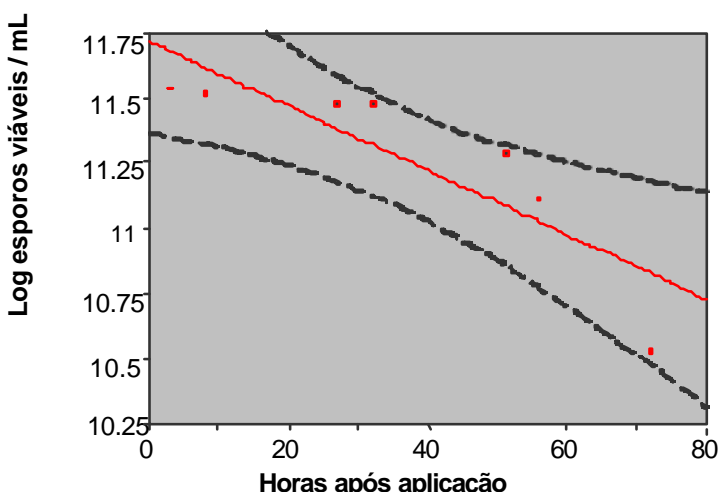

ECOTECH Escuro

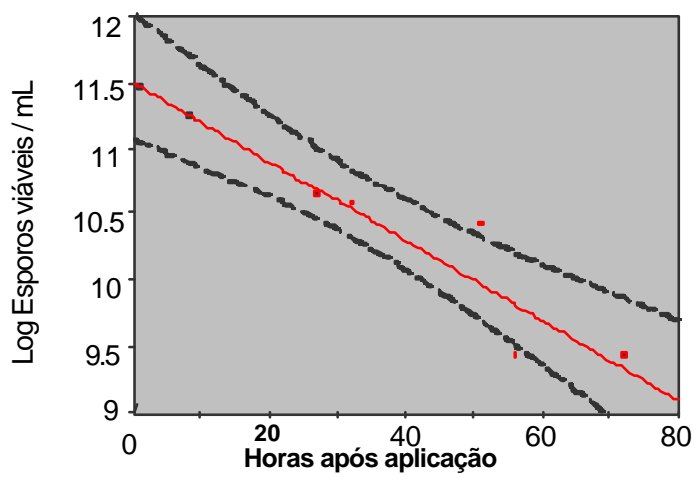

Dipel-Escuro

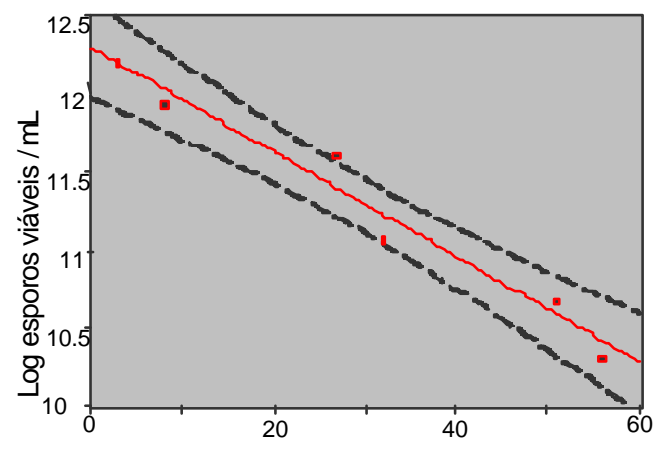

Figura 4 - Persistência de produtos à base de Bacillus thuringiensis em campo A (presença de ultravioleta) e em B.O.D. - B (ausência de ultravioleta). De cima para baixo: Bac-control, Ecotech e Dipel. Média de três concentrações 
Outro aspecto relevante é a evolução das formulações. Na década de 80, a formulação pó-molhável era praticamente impossível de molhar, obstruindo bicos, resultando falhas na aplicação (Couch \& Ignoffo, 1981). Atualmente, devido às melhorias tecnológicas, esta formulação é uma das mais eficientes, pois possui a melhor distribuição na superfície de aplicação (Batista Filho et al., 1998).

Nesse caso ficou evidente a ação negativa da radiação ultravioleta sobre a persistência deste patógeno. De acordo com Batista Filho et al. (1998), esta radiação atua diretamente nos ácidos nucléicos, alterando-os ou mesmo inativando-os, o que impede 0 crescimento e a multiplicação dos entomopatógenos e, no caso específico de Bt, os aminoácidos (cisteína, tirosina, e triptofano) dos cristais são afetados, inativando as toxinas. A inativação do esporo tem menos efeito sobre a virulência do $B t$, que em outros patógenos, pois as toxinas, responsáveis por grande parte da sua ação patogênica, estão contidas nos cristais. Entretanto, diversos trabalhos demonstram que a presença do esporo aumenta a persistência do $B t$, pois há multiplicação nos insetos mortos. Além disso, a aplicação de apenas cristais resulta em menor mortalidade de lagartas que a aplicação de ambas as estruturas, o que demonstra um papel secundário dos esporos, justificando a sua preservação.

Apesar da melhoria das formulações existentes, sua persistência ainda era muito aquém do desejado e buscaram-se então novas formulações, capazes de proporcionar um incremento significativo na persistência e, por conseqüência, melhorar sua eficiência. Nesse sentido foram feitas tentativas de encapsular as toxinas de Bt kurstaki (Dunkle \& Shasha, 1988; McGuire \& Shasha, 1989; McGuire et al., 1996). Estas formulações apresentaram um maior período de persistência em folhas de algodão cultivado em casa-devegetação (acima de duas semanas) e também uma maior eficiência contra pragas, como foi verificado para Ostrinia nubilalis, que mostrou maior 
suscetibilidade a formulações encapsuladas de Bt kurstaki (Glare \& O'Callagham, 2000).

Outro avanço foi obtido na década de 90 quando um novo bioinseticida denominado $\mathrm{MVP}^{\circledR}$ foi lançado no mercado. Este produto foi o resultado de mais de 10 anos de estudo, utilizando-se o sistema CellCap ${ }^{\circledR}$ como protetor dos ingrediente ativo de formulações. O MVP ${ }^{\circledR}$ tem maior persistência e eficiência que as outras formulações convencionais devido à presença de células de Pseudomonas fluorescens que encapsulam os componentes do produto, tornando-os mais resistentes às condições ambientais adversas, como radiação ultravioleta. Esta formulação mostrou-se muito eficiente para o controle de Helicoverpa zea no México, Honduras e EUA (Soares Júnior., 1996; Batista Filho et al., 1998).

\subsubsection{Bioensaios em casa-de-vegetação e campo}

Pela comparação da sobreposição dos intervalos de confiança, não foi constatada diferença estatística significativa entre a persistência do $B t$ em casade-vegetação e campo (Tabela 2), porém como o ajuste dos dados ao modelo exponencial foi abaixo do biologicamente recomendado $\left(R^{2}<0,70\right)$, a validação dos resultados foi prejudicada, indicando a necessidade de um maior número de repetições, em estudos posteriores. A aplicação do isolado ESALQ 3.7 não formulado pode ser responsável por essa inconsistência estatística. $\mathrm{O} B t$ não formulado sobre influência de outros fatores bióticos e abióticos, além da radiação ultravioleta, que afetam a sua permanência no substrato, prejudicando a condução de experimentos e a validação dos dados obtidos.

Em relação ao dano causado pelas lagartas de $S$. frugiperda no campo e em casa-de-vegetação, não foi verificada diferença significativa entre o tratamento e a testemunha (Tabela 3, Figuras 4 e 5). Pode-se afirmar que, o Bt não formulado foi incapaz de impedir o dano das lagartas de $S$. frugiperda no milho. Os dados mostram que a alta atividade do isolado ESALQ $3.7 \mathrm{em}$ 
laboratório (Capítulo 4), não se repetiu em de casa-de-vegetação e campo, ressaltando a importância da formulação de bioinseticidas para viabilizar a ação de seu ingrediente ativo, protegendo-o contra fatores que possam prejudicar a sua ação em campo.

Tabela 2. Estimativa da meia-vida $(\pi)$ (horas), intervalos de confiança $(P=0,10)$ e coeficiente de determinação $\left(\mathrm{R}^{2}\right)$ do isolado ESALQ 3.7 DE Bacillus thuringiensis em casa-de-vegetação e campo, sem ultravioleta (UV) e com ultravioleta (UV)

\begin{tabular}{ccc}
\hline Condições & Sem UV & Com UV \\
\hline Casa-de-vegetação & $6,4(4,53-11,08) R^{2}=0,63$ & $10,90(7,82-17,90) R^{2}=0,55$ \\
Campo & $7,9(5,61-13,8) R^{2}=0,21$ & $12,77(5,82-66,14) R^{2}=0,55$ \\
\hline
\end{tabular}

Tabela 3. Nota de dano causado por lagartas de Spodoptera frugiperda em plantas de milho, cultivadas em casa-de-vegetação e campo e inoculadas com o isolado ESALQ 3.7

\begin{tabular}{ccc}
\hline Tratamentos & \multicolumn{2}{c}{ Avaliações $^{1}$} \\
& 7 DAT & 14 DAT \\
\hline Casa-de-vegetação & \\
Testemunha & 2,50 a A & 3,00 a A \\
ESALQ 3.7 & 2,50 a A & 2,75 a A \\
Campo & & \\
Testemunha & 2,75 a A & 3,00 a A \\
ESALQ 3.7 & 2,50 a A & 2,75 a A
\end{tabular}

Médias seguidas pela mesma letra maiúscula nas linhas e minúscula nas colunas, não diferem entre si pelo teste de Tukey a $5 \%$ de probabilidade de erro.

${ }^{2}$ Dias após aplicação do tratamento. 

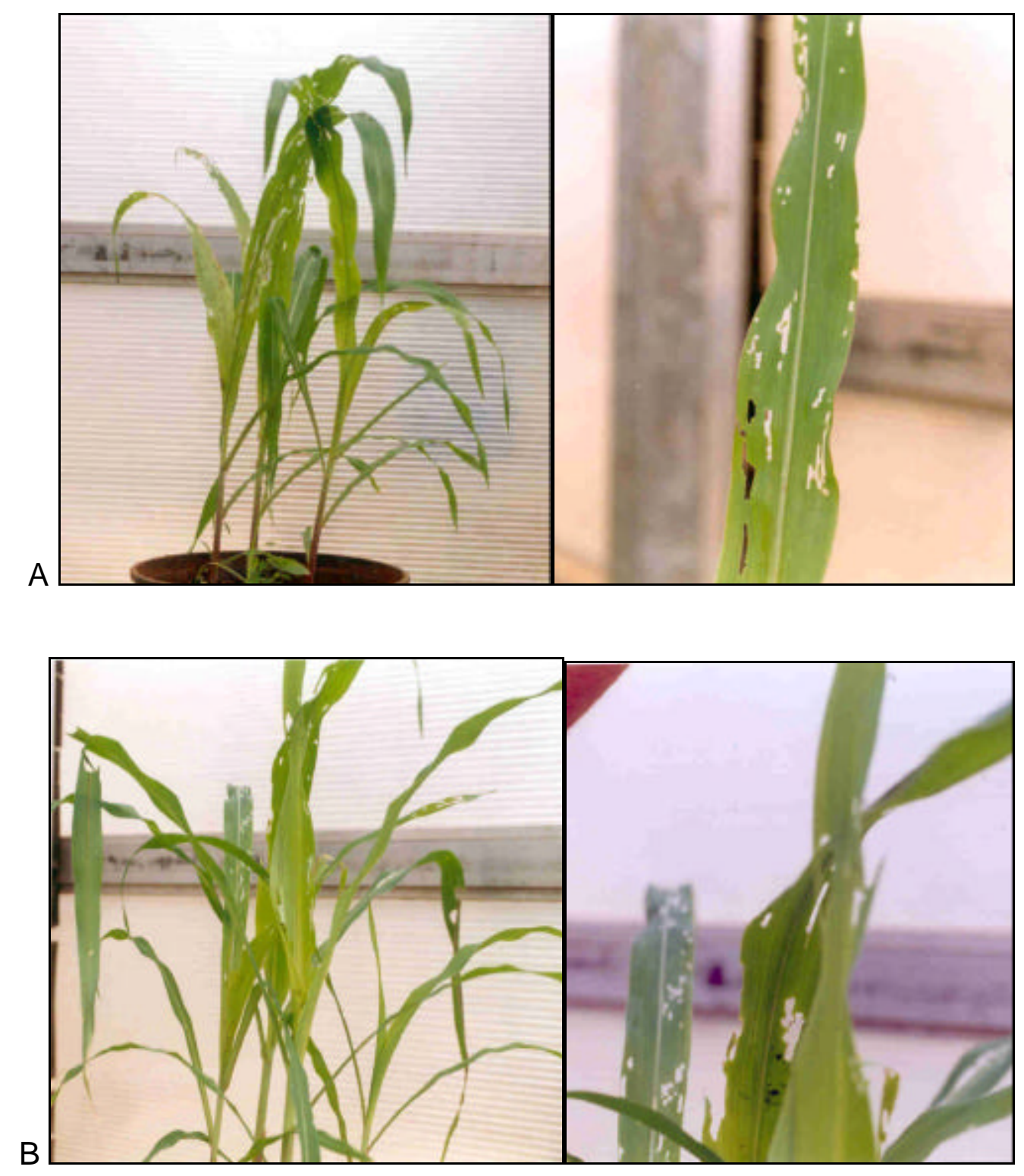

Figura 4 - Avaliação visual de dano de Spodoptera frugiperda em milho cultivado em casa-de-vegetação. A - testemunha e B - tratamento 

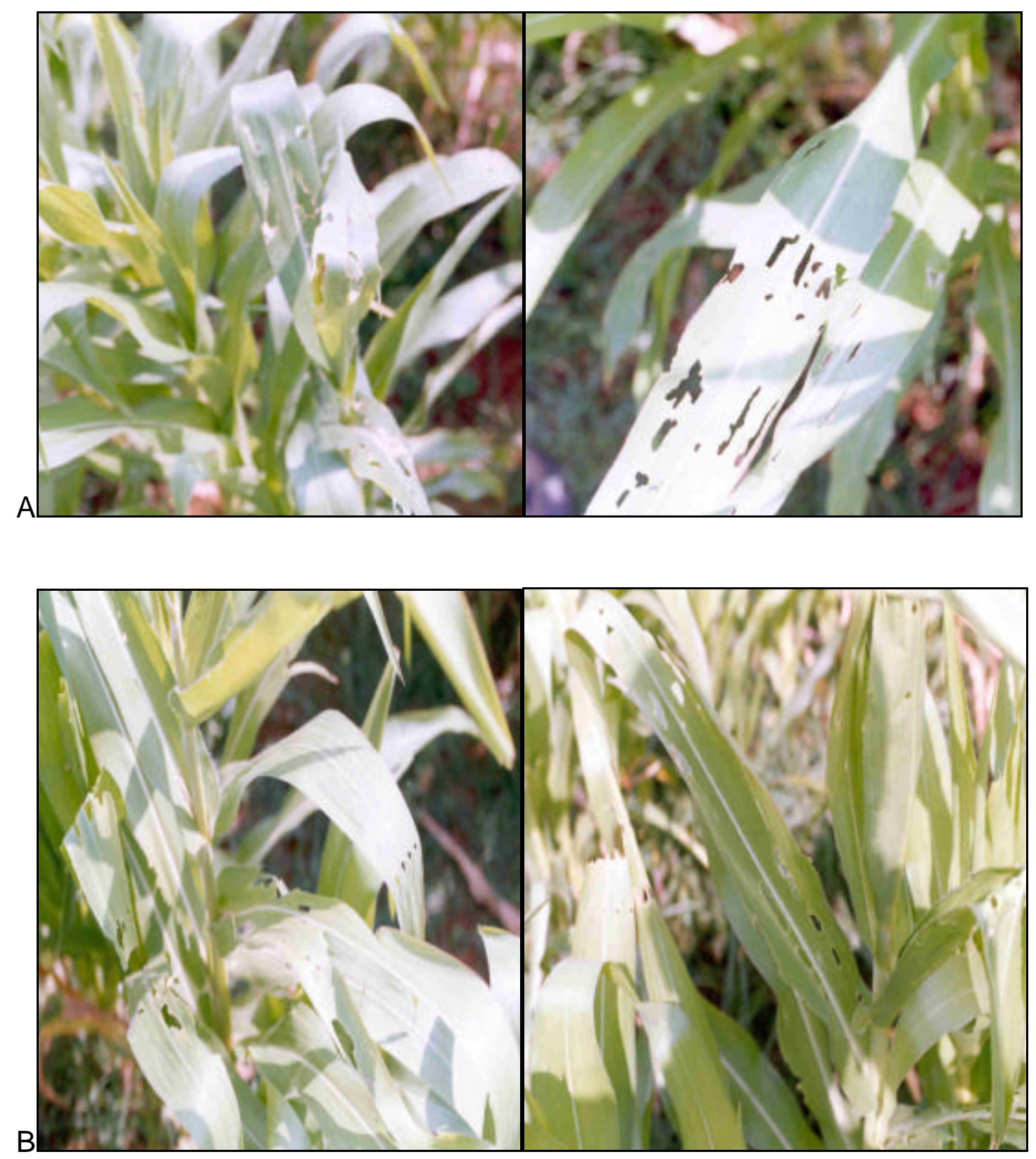

Figura 5 - Avaliação visual de dano de Spodoptera frugiperda em milho cultivado em campo. A - testemunha e B - tratamento 
Entre esses fatores, de acordo com Ben-Dov et al. (2003) e Glare \& O'Callagham (2000) estão: técnica de aplicação, substrato, substâncias químicas presentes na superfície das folhas e disposição das folhas, taxa de ingestão, presença de partículas e hábito alimentar do inseto.

\subsection{Conclusões}

Os formulados Dipel, Ecothech PRO e Bac-Control PM, apresentam diferenças no tempo de persistência em campo.

O isolado ESALQ 3.7 em campo e casa-de-vegetação foi influenciado por fatores bióticos e abióticos que prejudicaram a condução dos experimentos.

$O$ isolado ESALQ 3.7 não formulado não é eficaz, em casa-devegetação e campo, na redução de danos de $S$. frugiperda. 


\section{INTERAÇÃO DE Bacillus thuringiensis COM OUTROS ENTOMOPATÓGENOS NO CONTROLE DE Spodoptera frugiperda.}

\section{Resumo}

Avaliou-se em laboratório a interação de isolados de Bacillus thuringiensis (Bt) com Beauveria bassiana, Heterorhabditis sp., Nomuraea rileyi e um vírus de poliedrose nuclear (VPN), no controle da lagarta-do-cartucho, Spodoptera frugiperda. Para a realização dos bioensaios utilizou-se a concentração de $3 \times 10^{8}$ esporos $/ \mathrm{mL}$ para os isolados de Bt (ESALQ 2.4, 3.7 e 8.7); para o nematóide Heterorhabditis sp. foram utilizados cerca de 500, 2500 e 7500 juvenis infectivos $(\mathrm{JI}) / \mathrm{mL}$; para os fungos $B$. bassiana (isolados ESALQ 1074, 1115, 1117 e 1284) e $N$. rileyi (isolado ESALQ N1) utilizou-se $1 \times 10^{8}$ conídios/mL; e para o VPN foram testados cerca de $48 \times 10^{5}$ e $24 \times 10^{6}$ corpos de inclusões virais (cip)/mL. Para os bioensaios de interação utilizou-se a aplicação seqüencial dos entomopatógenos, com dois dias de intervalo entre os tratamentos. Observou-se que entre Bt e Heterorhabditis sp. ocorreu interação positiva, variando de efeito aditivo a sinergismo subaditivo, de acordo com a concentração do nematóide. Entre $B t$ e os fungos entomopatogênicos foi verificada interação negativa (antagonismo) e entre o VPN e Bt a interação foi negativa e positiva (efeito aditivo), dependendo da concentração do vírus. 


\section{Summary}

The interactions among Bacillus thuringiensis $(B t)$ and Beauveria bassiana, Heterorhabditis sp., Nomuraea rileyi and a nuclear plyhedrosis virus (NVP) to control the fall armyworm (Spodoptera frugiperda) have been assayed at laboratory. The bioassays were carried out with the concentration of $3 \times 10^{8}$ spores. $\mathrm{mL}^{-1}$ using $B t$ isolates (ESALQ 2.4, 3.7 and 8.7), the nematoid Heterorhabditis sp. using about 500, 2500 and 7500 infectives juveniles (IJ)/mL, the fungi $B$. bassiana (isolates 1074, 1115, 1117 e 1284) and $N$. rileyi (isolate ESALQ N1) using used $1 \times 10^{8}$ conidia. $\mathrm{mL}^{-1}$ and the NVP testing $48 \times 10^{5}$ e 24 $\times 10^{6}$ parasporal inclusions bodies (pib) $\mathrm{mL}^{-1}$. For the interaction bioassays was done the sequencial application of the control agents, adopting two days between applications. It was observed positive interaction between $B t$ and Heterorhabditis $\mathrm{sp}$. This interaction varied from additive effect to subaditive sinergism, according to nematode concentration. The interaction between $B t$ and entomopathogenic fungi was negative (antagonism) and to VPN and Bt it was negative or positive (aditive effect), depending on NVP concentration.

\subsection{Introdução}

A interação entre inseticidas e produtos formulados com Bacillus thuringiensis $(B t)$ foi amplamente estudada e, em alguns casos, foram obtidos resultados satisfatórios (Benz, 1971). Esta interação baseia-se no princípio de que $o$ inseticida atua como agente estressante do inseto, levando-o a adquirir ou ativar doenças infecciosas, tornando-o mais suscetível às toxinas do $B t$.

Mais recentemente, o estudo da interação de bioinseticidas à base $B t$ e outros entomopatógenos ganhou mais ênfase (Glare \& O'Callagham, 2000). A compatibilidade com outros bioinseticidas ou com agentes naturais de controle é importante no desenvolvimento de estratégias que utilizam entomopatógenos em programas de Manejo Integrado de Pragas (Gardner et al. 1984). É 
essencial, nesses casos, estudar as interações potenciais, principalmente para viabilizá-las economicamente e também para avaliar seu impacto sobre 0 ambiente. Porém, o estudo destas interações tem um elevado grau de complexidade e as respostas sinérgicas são raras, mesmo em laboratório (Koppenhöfer \& Kaya, 1997). As mesmas dificuldades, até em maior grau, são observadas em campo.

Apesar dessas dificuldades, alguns estudos de laboratório avaliaram o sinergismo de Bt com outros entomopatógenos. Koppenhöfen et al. (1999), Koppernhofer \& Kaia (1997) e Shamseldean \& Ismail (1997) estudaram o efeito da interação do nematóide entomopatogênico $H$. bacteriophora e Steinernema glaseri com Bt, e observaram efeito sinérgico para Cyclocephala hirta, $C$. pasadenae e Agrotis ipsilon, respectivamente. A interação de vírus entomopatogênicos com Bt para o controle de espécies-praga é o caso mais estudado de interação entre entomopatógenos, envolvendo principalmente o controle de Heliothis virescens, Spodoptera spp. e Trichoplusia ni (Glare \& O'Callagham, 2000), porém os exemplos de interação envolvendo $S$. frugiperda são raros (López-Lastra et al. 1995). Estudos que avaliam as interações de Bt com fungos entomopatogênicos são escassos (Ignoffo et al., 1980; El-Maghraby et al., 1988; Lewis \& Bing, 1991) e apresentam resultados variáveis.

Neste trabalho, avaliou-se em laboratório o efeito da interação dos

fungos entomopatogênicos $B$. bassiana e $N$. rileyi, de um vírus de poliedrose nuclear de $S$. frugiperda (VPNSf) e do nematóide entomopatogênico Heterorhabditis sp. com isolados de Bt no controle de $S$. frugiperda.

\subsection{Material e Métodos}

\subsubsection{Avaliação da interação do nematóide entomopatogênico (Heterorhabditis sp.) e Bacillus thuringiensis}


O nematóide foi isolado de amostra de solo procedente de campo de citros na região de Itapetininga-SP. Para manutenção e utilização nos bioensaios o mesmo foi produzido in vitro pelo método da esponja (Bedding, 1981) no Instituto Biológico em Campinas - SP. As lagartas de S. frugiperda, provenientes de São Paulo, foram obtidas de criação laboratorial mantida nos Laboratórios de Resistência de Plantas a Insetos e Biologia de Insetos (ESALQUSP).

Os bioensaios foram realizados no Laboratório de Patologia e Controle Microbiano de Insetos (ESALQ-USP). A câmara de Peters foi utilizada para a determinação das concentrações de cerca de 500, 2500 e 7500 juvenis infectivos $(\mathrm{Jl}) / \mathrm{mL}$, o que corresponde a aproximadamente $10^{8}, 5 \times 10^{8}$ e $1,6 \times$ $10^{9} \mathrm{JI} / \mathrm{ha}$. Para obter estes valores, utilizou-se uma suspensão preparada a partir da esponjas utilizadas na criação do nematóide. Esses valores são utilizados para estudos laboratoriais visando ao controle de larvas do besouro da raíz dos citros (Naupactus sp.) (Leite et al., 2003) e foram utilizados como referência na condução destes bioensaios. Cada concentração foi aplicada sobre papel filtro colocado no interior de placa de Petri plástica $(5,0 \times 1,5 \mathrm{~cm})$, utilizando-se 45 placas por tratamento, divididas em 3 repetições. $\mathrm{Na}$ testemunha foi utilizada água destilada esterilizada, adaptado de Molina-Ochoa et al. (1996). Após a aplicação dos tratamentos as lagartas de segundo instar foram individualizadas no interior das placas.

Nos bioensaios de $B t$ foram utilizados três isolados (ESALQ 2.4, 3.7 e 8.7 previamente testados para $S$. frugiperda (Capítulo 4). Estes isolados foram multiplicados em meio de cultura BHI (Infusão de Cérebro e Coração - Caldo $\mathrm{BHI}$ da $\mathrm{AZ}$ Labor) a $28^{\circ} \mathrm{C}$, e $180 \mathrm{rpm}$ por 76 horas para um crescimento padrão dos mesmos. Após a lise bacteriana, a mistura contendo esporos, cristais e células vegetativas foi submetida a três centrifugações consecutivas $(5.000 \mathrm{rpm}$ por 20 minutos), a fim de eliminar o meio de cultura e lavar o concentrado obtido, eliminando toxinas extra celulares como as $\beta$-exotoxinas. 
Após a multiplicação do isolado, uma alíquota deste $(1 \mathrm{~mL})$ foi diluída 1000 vezes em água destilada esterilizada, e a concentração de esporos foi determinada conforme método descrito por Alves \& Moraes (1998). Para os bioensaios, uma alíquota de $100 \mu \mathrm{L}$ de suspensão de Bt na concentração de $3 \mathrm{x}$ $10^{8}$ esporos $/ \mathrm{mL}$ foi aplicada na superfície do disco de dieta artificial (Burton \& Perkins, 1972), previamente distribuída em placas de acrílico. Após a evaporação do excesso de umidade, 45 lagartas de segundo ínstar, distribuídas em três repetições, foram acondicionadas individualmente. No lote correspondente à testemunha foi aplicada água destilada e esterilizada, em volume equivalente aos lotes tratados.

Nos bioensaios de interação, as lagartas foram inicialmente submetidas à inoculação com $B t$, e dois dias após foram transferidas para placas contendo os nematóides. Conforme Gardner et al. (1984) e Jaques \& Morris (1981), a aplicação seqüencial dos tratamentos em estudos de interação de entomopatógenos tem maior probabilidade de êxito. Além disso, essa transferência foi necessária devido aos diferentes substratos utilizados nos experimentos.

\subsubsection{Avaliação da interação entre fungos entomopatogênicos (B. bassiana e N. rileyi) x Bacillus thuringiensis}

Os bioensaios com $B t$ foram realizados conforme o item 6.2.1. Para $B$. bassiana foram testados os isolados 1074, 1115, 1117 e 1284, pertencentes ao Banco de Entomopatógenos do Laboratório de Patologia e Controle Microbiano de Insetos (ESALQ/USP). O isolado de $N$. rileyi (ESALQ N1), utilizado nos experimentos foi obtido durante coleta de lagartas na área experimental do Departamento de Entomologia, Fitopatologia e Zoologia Agrícola (ESALQ/USP).

Para os fungos entomopatogênicos, foram testadas 45 lagartas de segundo instar da população de São Paulo, distribuídas em 3 repetições e uma testemunha. Para a realização dos bioensaios o isolado foi repicado e 
multiplicado em meio de cultura M.C. $\left(0,18 \mathrm{~g} \mathrm{KH}_{2} \mathrm{PO}_{4}, 0,525 \mathrm{~g} \mathrm{Na}_{2} \mathrm{HPO}_{4}, 0,30 \mathrm{~g}\right.$ $\mathrm{MgSO}_{4}, 0,50 \mathrm{~g} \mathrm{KCl}, 5,0 \mathrm{~g}$ Glicose, 0,79 $\mathrm{g} \mathrm{NaNO}_{3}$, 2,5 g extrato de levedura, 10 $\mathrm{g}$ ágar, $1 \mathrm{~L}$ água destilada). Uma suspensão de $100 \mu \mathrm{L}$ do patógeno, na concentração de $1 \times 10^{8}$ conídios $/ \mathrm{mL}$ (utilizada para discriminar isolados patogênicos), foi aplicada na superfície do disco de dieta artificial (Burton \& Perkins, 1972), previamente distribuída em placas de acrílico (35 mm de diâmetro). Após a evaporação do excesso de umidade, as lagartas foram acondicionadas individualmente. No lote correspondente a testemunha foi aplicada água destilada e esterilizada, em volume equivalente aos lotes tratados.

Assim como nos bioensaios envolvendo Bt e Heterorhabditis sp., nesse caso a aplicação dos tratamentos foi realizada com dois dias de intervalo, sendo inicialmente aplicado o $B t \mathrm{e}$, posteriormente, os fungos entomopatogênicos. Os bioensaios foram realizados conforme o método utilizado para os bioensaios individuais, descritos no início deste item.

\subsubsection{Avaliação da interação entre Virus de Poliedrose Nuclear de S. frugiperda (VPNSf) $\times$ Bacillus thuringiensis}

Os bioensaios com $B t$ foram realizados conforme o item 6.2.1. O vírus de Poliedrose Nuclear (VPNSf) foi obtido junto à Embrapa de Milho e Sorgo (Sete Lagoas - MG). Para a realização dos testes foram utilizadas 45 lagartas de segundo ínstar de $S$. frugiperda. Foram empregadas as concentrações de $48 \times 10^{5}$ e $24 \times 10^{6}$ corpos de inclusões virais (cip) $/ \mathrm{mL}$, correspondentes à $2,5 \times$ $10^{11}$ e $1,25 \times 10^{12}$ cip/ha (Cruz et al., 1996), na formulação de pó molhável. Uma alíquota de $0,1 \mathrm{~mL}$ destas concentrações foi aplicada sobre a superfície da dieta artificial (Burton \& Perkins, 1972).

Assim como no bioensaio de interação anterior, nesse caso a aplicação dos tratamentos foi realizada com dois dias de intervalo, sendo inicialmente aplicado o Bte, posteriormente o vírus. 
Em todos os bioensaios, o acondicionamento do material foi feito em câmara incubadora tipo B.O.D., regulada para $25 \pm 0,5^{\circ} \mathrm{C}, 65 \pm 10 \%$ de UR e 12 horas de fotofase. Os tratamentos foram avaliados diariamente até o $8^{\circ}$ dia (Bt e nematóide e sua interação) e $12^{\circ}$ dia (fungos, vírus e sua interação com Bt) após a aplicação. A mortalidade foi corrigida conforme Abbott (1925) e para avaliação do grau de interação entre os entomopatógenos foi adaptada terminologia utilizada por Benz (1971):

1 - Sinergismo independente: é um sistema onde os dois componentes atuam de maneira independente, sem interferência entre eles. A mortalidade (\%) resultante deste sinergismo pode ser expressa por: $A_{1+2}=A_{1}+$ $A_{2}\left(1-A_{1} / 100\right)$, onde: $A_{1}$ e $A_{2}$ correspondem a mortalidade causada pelos agentes 1 e 2 , respectivamente.

2 - Sinergismo suplementar: é um sistema com dois componentes efetivos que em conjunto produzem um efeito maior que a soma algébrica dos efeitos independentes $\left(A_{1+2}>A_{2}+A_{2}\right)$.

3 - Sinergismo subaditivo: é um sistema onde os dois componentes atuando em conjunto produzem um efeito maior que o sinergismo independente, porém menor que a soma algébrica dos dois efeitos individuais.

4 - Efeito aditivo: é um sistema onde os dois componentes atuando em conjunto produzem um leve incremento no seu efeito, em relação a atuação dos componentes individuais, porém insuficiente para ser considerado sinergismo.

5 - Antagonismo: é um sistema onde a interação dos elementos produz um efeito menor do que suas atuações individuais. Nesse caso a interação e considerada negativa, enquanto que nos outros quatro exemplos, acima citados, é considerada positiva. 


\subsection{Resultados e Discussão}

\subsubsection{Nematóide entomopatogênico (Heterorhabditis sp.) X Bacillus thuringiensis}

No estudo da interação entre os isolados de $B t$ e o nematóide entomopatogênico Heterorhabditis sp., verificou-se interação positiva entre os isolados de $B t$ testados e as concentrações do nematóide (Tabela 1). Para os isolados ESALQ 2.4 e 8.7 o aumento da concentração do nematóide determinou a efeito sinérgico entre os entomopatógenos, uma vez que o sinergismo subaditivo somente foi obtido na maior concentração deste, enquanto que nas demais foi observado efeito aditivo. Para o isolado ESALQ 3.7 foi possível apenas determinar que houve interação positiva entre este isolado e o nematóide, em todas as concentrações. Este fato se deve a alta mortalidade individual causada pelos agentes envolvidos. Em geral, este elevado grau de interação positiva pode se explicado, em parte, pela rápida ação destes dois patógenos (Baur et al., 1998; Knowles, 1994).

Em relação à alta atividade do nematóide para a lagarta-do-cartucho (60-80\% de mortalidade), estes dados corroboram com os obtidos por MolinaOchoa et al. (1996), que estudando a eficiência de diferentes espécies de nematóides para $S$. frugiperda, verificou que $H$. bacteriophora na concentração de 100 nematóides $/ \mathrm{mL}$ causou mortalidade de 64,7\% em lagartas dessa espécie.

Heterorhabditis spp. associam-se a bactérias, com as quais estabelecem relação mutualística, oferecendo proteção à bactéria fora do corpo do hospedeiro e transportando seus vetores, do cadáver de um inseto, ao hemoceloma de outro. Já as bactérias servem de alimento aos nematóides, provendo-lhes meio nutritivo adequado ao desenvolvimento e à reprodução (Ferraz, 1998).

O processo infectivo desses entomopatógenos ainda não foi totalmente elucidado (Ribeiro et al., 1999), porém o cadáver fica tomado por 
verdadeira "sopa bacteriana", ou seja, um meio rico em nutrientes constituído pelas bactérias e por tecidos já desorganizados do inseto, a partir do qual os nematóides alimentam-se e desenvolvem-se.

Tabela 1. Interação entre Bacillus thuringiensis e o nematóide Heterorhabditis sp. no controle de lagartas de segundo ínstar de Spodoptera frugiperda

\begin{tabular}{|c|c|c|}
\hline Entomopatógenos & $\begin{array}{l}\text { Mortalidade } \\
\text { Corrigida (\%) }\end{array}$ & Tipo de interação \\
\hline ESALQ 2.4 & $55,00 \pm 4,0$ & - \\
\hline ESALQ 3.7 & $82,00 \pm 3,0$ & - \\
\hline ESALQ 8.7 & $62,00 \pm 4,5$ & - \\
\hline Nematóide $1\left(10^{8} \mathrm{Jl} / \mathrm{ha}\right)$ & $66,66 \pm 3,0$ & - \\
\hline Nematóide $2\left(5 \times 10^{8} \mathrm{Jl} / \mathrm{ha}\right)$ & $80,00 \pm 2,5$ & - \\
\hline Nematóide $3\left(1,6 \times 10^{9} \mathrm{JI} / \mathrm{ha}\right)$ & $80,00 \pm 7,0$ & - \\
\hline ESALQ 2.4 x Nematóide 1 & $77,00 \pm 9,5$ & efeito aditivo \\
\hline ESALQ 2.4 x Nematóide 2 & 100 & sinergismo subaditivo \\
\hline ESALQ 2.4 x Nematóide 3 & 100 & sinergismo subaditivo \\
\hline ESALQ 3.7 x Nematóide 1 & $97,50 \pm 4,0$ & interação positiva \\
\hline ESALQ 3.7 x Nematóide 2 & $91,00 \pm 2,0$ & interação positiva \\
\hline ESALQ 3.7 x Nematóide 3 & 100,00 & interação positiva \\
\hline ESALQ 8.7 x Nematóide 1 & $79,00 \pm 1,5$ & efeito aditivo \\
\hline ESALQ 8.7 x Nematóide 2 & $97,00 \pm 3,0$ & efeito aditivo \\
\hline ESALQ 8.7 x Nematóide 3 & 100,00 & sinergismo subaditivo \\
\hline
\end{tabular}

$\mathrm{Na}$ América Latina, a empresa Probioma (Bolívia) comercializa Heterorhabditis spp. com o nome comercial Probione para o controle de Spodoptera sp., P. xylostella, Trichoplusia ni, Pseudoplusia incluidens, Diaphania hyalinata, Leptophobia sp., Phyllophaga sp., Diabrotica sp., Agrotis sp., Cylas formicarius, Euscepes sp., Cosmopolites sordidus, Pachnaeus litus, 
Hypothenemus hampei e Pseudococcidae em cerca de 20 culturas. Além da alta eficiência esse nematóide não apresenta efeito sobre insetos polinizadores; tem capacidade de reproduzir-se em campo nos insetos que parasita, portanto apresenta um controle duradouro; pode ser utilizado em conjunto com outras medidas de controle biológico; é capaz de se movimentar no solo para encontrar o hospedeiro; possibilita a aplicação por meios convencionais e pode ser utilizado na agricultura orgânica. A aplicação deste nematóide é feita com esponjas (40/ha), sendo que cada esponja contém cerca de 3 milhões de nematóides. Poinar (1971), ressalta que fatores físicos do solo podem influenciar a eficiência dos nematóides entomopatogênicos. Entre esses fatores, o autor afirma que a alta umidade do solo é essencial para a longevidade satisfatória destes nematóides.

Koppenhöfer et al. (1999) e Koppenhöfer \& Kaya (1970) ressaltaram que o efeito sinérgico entre os nematóides entomopatogênicos e Bt japonensis, para o controle de $C$. hirta e $C$. pasadenae, tanto em casa-de-vegetação como em campo, foi maior quando os entomopatógenos foram aplicados em seqüência, com intervalo de sete dias entre a aplicação dos tratamentos, e que os estágios mais suscetíveis dos insetos são os primeiros ínstares larvais. Os autores afirmam que as larvas inoculadas com Bt japonensis estressam devido à presença do patógeno, ficando mais suscetíveis à ação do nematóide, posteriormente aplicado.

Quando os dois microrganismos são aplicados ao mesmo tempo, o nematóide afeta menos as larvas, pois uma proporção destas conseguem resistir ao seu ataque utilizando mecanismos fisiológicos e estruturais defensivos. Além do mais, durante esta defesa a larva cessa sua alimentação, ingerindo menos $B t$, reduzindo significativamente o efeito deste patógeno. Portanto, nesta interação, o estresse inicial causado pelo Bt é essencial para que ocorra interação positiva (efeito aditivo ou sinergismo) entre os agentes de controle. O intervalo de dois dias entre a aplicação dos tratamentos nos bioensaios realizados no presente estudo, foi suficiente para causar o mesmo 
efeito verificado nos trabalhos anteriormente citados, resultando no sinergismo entre os tratamentos aplicados.

A defesa dos insetos aos nematóides inclui: supressão pelas células responsáveis pela primeira linha de defesa (hemócitos), inibição causada pelos peptídeos antibacterianos produzidos pelo inseto e supressão pela atividade da feniloxidases (substâncias antimicrobianas). O modo como esses mecanismos de defesa atuam ainda não foi totalmente esclarecido, mas estes compõem uma série de respostas fisiológicas complexas, cuja intensidade varia de acordo com o hospedeiro e o patógeno envolvidos (Ribeiro et al., 1999).

Embora neste trabalho tenha sido observado sinergismo entre os isolados de Bt e Heterorhabditis sp., o mesmo não foi verificado com o nematóide entomopatogênico Steinernema carpocapse e Bt kurstaki no controle da traça-das-crucíferas (Plutella xylostella). Ao contrário, Baur et al. (1999) verificaram efeito antagônico entre estes dois patógenos para uma linhagem de $P$. xylostella resistente a $B t$.

Isto mostra que existe uma série de fatores que influenciam o sucesso da interação entre $B t$ e nematóides entomopatogênicos. Talvez a mais importante delas seja a agressividade do nematóide, pois este desencadeia uma série de eventos comportamentais no inseto que determinam sua suscetibilidade ao outro patógeno envolvido na interação.

\subsubsection{Fungos entomopatogênicos (Beauveria bassiana e Nomuraea rileyi) $x$ Bacillus thuringiensis}

A interação entre os isolados e os fungos entomopatogênicos resultou em antagonismo entre os agentes de controle. Esse efeito antagônico foi mais severo entre os isolados ESALQ 2.4 e ESALQ 3.7, pois o efeito da interação foi menor do que a atividade individual destes isolados, indicando que, nesse caso, os fungos inibiram a ação do Bt. O mesmo efeito foi observado para o isolado ESALQ 8.7, porém em menor intensidade (Tabela 2). 
A inibição da ação do $B t$, pode ser devida à diminuição da ingestão do alimento com Bt quando o fungo é inoculado no inseto, devido ao início de uma série de reações fisiológicas envolvidas no mecanismo de defesa do inseto, assim como foi verificado para a interação Heterorhabditis sp. e Bt. Outra explicação pode ser a competição entre os entomopatógenos pelo hospedeiro (Glare \& O'Callagham, 2000).

O Bt que atua por ingestão tem sua ação inicialmente limitada ao aparelho digestivo do inseto, porém com a redução do $\mathrm{pH}$ intestinal, causada pela ação das toxinas Cry, os esporos disseminam-se pelo corpo do inseto, causando contaminação generalizada (Glare \& O'Callagham, 2000). É neste momento que pode ocorrer a competição com os fungos entomopatogênicos, durante a colonização do hospedeiro pelos fungos, quando suas estruturas envolvidas neste processo encontram os esporos do Bt. A colonização do fungo ocorre após a penetração do tegumento do inseto e caracteriza-se pelo engrossamento da hifa que penetra no hospedeiro e sua ramificação, inicialmente no tegumento e posteriormente na hemocele do hospedeiro. (Alves, 1998b).

Com relação à ação desses fungos sobre a lagarta-do-cartucho, Gardner \& Fuxa (1980) e Gardner et al. (1984) observaram mortalidade semelhante (30 a 45\%) em estudos de laboratório. Os autores ressaltam que embora estes microrganismos sejam freqüentemente encontrados infectando lagartas no campo, sua virulência é reduzida, sendo necessária a realização de bioensaios de seleção para a obtenção de um isolado mais eficaz.

Resultados semelhantes na interação entre $B$. bassiana e $B t$ foram verificados por El-Magharaby et al. (1988). Os autores observaram o antagonismo entre os patógenos no sistema parasitóide $\mathrm{x}$ hospedeiro, Microplitis / Spodoptera. Segundo os autores, esta interação negativa, é resultante da incompatibilidade entre os microrganismos. 
Tabela 2. Interação entre Bacillus thuringiensis e fungos entomopatogênicos para o controle de lagartas de segundo instar de Spodoptera frugiperda

\begin{tabular}{ccc}
\hline Entomopatógenos & $\begin{array}{c}\text { Mortalidade } \\
\text { Corrigida (\%) }\end{array}$ & Tipo de interação \\
\hline ESALQ 2.4 & $53,00 \pm 5,0$ & - \\
ESALQ 3.7 & $80,00 \pm 6,4$ & - \\
ESALQ 8.7 & $61,00 \pm 7,1$ & - \\
Beauveria bassiana 1 (1074) & $30,00 \pm 5,2$ & - \\
Beauveria bassiana 2 (1115) & $33,00 \pm 3,7$ & - \\
Beauveria bassiana 3 (1117) & $45,00 \pm 2,5$ & - \\
Beauveria bassiana 4 (1284) & $40,00 \pm 4,5$ & - \\
Nomuraea rileyi (ESALQ N1) & $33,00 \pm 4,5$ & - \\
ESALQ 2.4 x Beauveria bassiana 1 & $43,00 \pm 3,2$ & antagonismo \\
ESALQ 2.4 x Beauveria bassiana 2 & $33,00 \pm 2,0$ & antagonismo \\
ESALQ 2.4 x Beauveria bassiana 3 & $38,00 \pm 3,0$ & antagonismo \\
ESALQ 2.4 x Beauveria bassiana 4 & $41,00 \pm 3,0$ & antagonismo \\
ESALQ 3.7 x Beauveria bassiana 1 & $43,50 \pm 4,5$ & antagonismo \\
ESALQ 3.7 x Beauveria bassiana 2 & $29,00 \pm 3,0$ & antagonismo \\
ESALQ 3.7 x Beauveria bassiana 3 & $53,00 \pm 4,0$ & antagonismo \\
ESALQ 3.7 x Beauveria bassiana 4 & $47,00 \pm 5,0$ & antagonismo \\
ESALQ 8.7 x Beauveria bassiana 1 & $49,00 \pm 7,0$ & antagonismo \\
ESALQ 8.7 x Beauveria bassiana 2 & $57,00 \pm 2,0$ & antagonismo \\
ESALQ 8.7 x Beauveria bassiana 3 & $54,00 \pm 3,0$ & antagonismo \\
ESALQ 8.7 x Beauveria bassiana 4 & $58,00 \pm 3,0$ & antagonismo \\
ESALQ 2.4 x ESALQ N1 & $40,00 \pm 3,5$ & antagonismo \\
ESALQ 3.7 x ESALQ N1 & $42,00 \pm 4,0$ & antagonismo \\
ESALQ 8.7 x ESALQ N1 & $45,00 \pm 5,0$ & antagonismo \\
\hline
\end{tabular}


De acordo com Krieg (1971), estudos realizados com o objetivo de utilizar $B$. bassiana e $B t$ no controle de ortópteros e coleópteros, obtiveram resultados pouco satisfatórios. Do mesmo modo, Lewis \& Bing (1991), realizaram um programa em campo para o controle de Ostrinia nubilalis utilizando-se Bt kurstaki e $B$. bassiana. Os autores não observaram efeito positivo ou negativo quando aplicaram os dois tratamentos ao mesmo tempo, sendo que os resultados foram altamente satisfatórios nas combinações testadas. Os resultados da literatura aqui citados e os obtidos neste trabalho indicam que a interação entre fungos e $B t$ pode resultar em efeitos variáveis. Provavelmente, esta variação está ligada à variação entre as subespécies e/ou toxinas e também à espécie de inseto com a qual foram realizados os testes.

\subsubsection{Virus de Poliedrose Nuclear de S. frugiperda (VPNSf) $x$ Bacillus thuringiensis}

Neste estudo a interação entre os agentes de controle variou de positiva (efeito aditivo) a antagônica (negativa) (Tabela 3). Entre os isolados ESALQ 2.4 e ESALQ 8.7 e a maior concentração do vírus foi observado um leve efeito aditivo, enquanto que nos demais casos foram verificados efeitos antagônicos. Neste caso fica claro que o sucesso da interação depende da concentração do vírus, sendo que, aparentemente, quanto maior a concentração maior a possibilidade de interação positiva.

A infecção das lagartas pelo baculovirus ocorre pela ingestão de alimento contaminado com corpos de inclusão virais, que são solubilizados no intestino médio do inseto, liberando os vírions. Estes infectam as células epiteliais, em cujos núcleos os vírus se replicam, resultando num segundo tipo viral com a capacidade de infectar outros tecidos, como a hemolinfa e através desta acarretar a infecção sistêmica (Andrade et al., 2003). O intestino médio também é o local de ação das toxinas do Bt (Knowles, 1994). Este fato pode explicar o antagonismo na interação entre o vírus e o Bt. 
Resultados diferentes aos obtidos neste trabalho foram verificados por López-Lastra et al. (1995). Em condições de campo, os autores observaram que na interação entre a toxina Cry1Ac e um vírus de poliedrose nuclear no controle de $S$. frugiperda não resultou em efeito sinérgico nem antagônico.

Tabela 3. Interação entre Bacillus thuringiensis e um vírus de poliedrose nuclear para o controle de lagartas de segundo instar de Spodoptera frugiperda

\begin{tabular}{|c|c|c|}
\hline Entomopatógenos & $\begin{array}{c}\text { Mortalidade } \\
\text { Corrigida (\%) }\end{array}$ & $\begin{array}{c}\text { Tipo de } \\
\text { interação }\end{array}$ \\
\hline ESALQ 2.4 & $59,00 \pm 4,0$ & - \\
\hline ESALQ 3.7 & $87,00 \pm 3,5$ & - \\
\hline ESALQ 8.7 & $64,00 \pm 2,0$ & - \\
\hline VPNSf $1\left(2,5 \times 10^{11}\right.$ poliedros/ha) & $75,00 \pm 3,0$ & - \\
\hline VPNSf2 $\left(1,25 \times 10^{12}\right.$ poliedros/ha) & $66,00 \pm 3,5$ & - \\
\hline ESALQ $2.4 \times$ VPNSf 1 & $60,00 \pm 4,0$ & antagonismo \\
\hline ESALQ $2.4 \times$ VPNSf2 & $68,00 \pm 2,5$ & efeito aditivo \\
\hline ESALQ $3.7 \times$ VPNSf 1 & $66,50 \pm 3,0$ & antagonismo \\
\hline ESALQ 3.7 x VPNSf2 & $79,00 \pm 5,0$ & antagonismo \\
\hline ESALQ $8.7 \times$ VPNSf 1 & $58,00 \pm 6,0$ & antagonismo \\
\hline ESALQ $8.7 \times$ VPNSf2 & $77,00 \pm 4,0$ & efeito aditivo \\
\hline
\end{tabular}

Devido à alta eficiência deste patógeno no controle de $S$. frugiperda (Cruz et al., 2000; Valicente \& Cruz, 1991), um programa nacional de utilização de VPNSf foi implementado pela Embrapa Milho e Sorgo, utilizando-se um isolado tão eficiente quanto os inseticidas convencionais. Neste programa a multiplicação do VPN foi feita em lagartas de $S$. frugiperda criadas individualmente, em dieta artificial, e posterior formulação do patógeno como pó-molhável, para distribuição aos produtores de milho. O produto biológico é atualmente utilizado em pequena escala no Brasil, mas os aperfeiçoamentos 
realizados, principalmente quanto à produção e utilização, indicam possibilidade de aumento gradativo da sua utilização (Moscardi, 1998).

Os dados obtidos neste trabalho estão de acordo com as observações feitas por Benz (1971). Esse autor afirma que é não é apropriado fazer generalizações sobre a interação entre entomopatógenos, pois muitas vezes o resultado da interação depende mais das concentrações utilizadas do que do patógeno. Além disso, a falta de padronização dos termos utilizados nestes estudos dificulta a interpretação e comparação dos resultados.

A variação nos resultados obtidos nestes experimentos mostra que a interação entre entomopatógenos e outros agentes de controle pode ser um instrumento essencial no controle de pragas importantes, como é o caso de $S$. frugiperda. No entanto, deve-se verificar se esta interação ocorre em condições de campo, onde fatores bióticos e abióticos podem afetar significativamente a ação dos agentes de controle. Devido a complexidade de fatores no ambiente natural, a definição dos parâmetros a serem avaliados a campo é importante para evitar desperdício de material, tempo e trabalho. Em sistemas agrícolas com uso constante de bioinseticidas e cujas pragas são reguladas por outros patógenos, que atuam como agentes do controle biológico natural, os estudos de suas interações devem ser considerados com maior ênfase.

\subsection{Conclusões}

Ocorre interação positiva (efeito aditivo e sinergismo subaditivo), entre os isolados de Bt e o nematóide entomopatogênico Heterorhabditis sp. para o controle da lagarta-do-cartucho.

A interação entre o $B t$ e os fungos entomopatogênicos no controle de $S$. frugiperda ( $B$. bassiana e $N$. rileyi) é negativa (antagônica).

ocorre interação negativa (antagonismo) e positiva (efeito aditivo) entre os isolados de $B t$ e o vírus de poliedrose nuclear (VPN), no controle da lagarta-do-cartucho. 


\section{CONCLUSÕES GERAIS}

- Todas as amostras de solos processadas possuem esporos de Bt.

- As características químicas dos solos afetam a presença de Bt em campo.

- O isolado ESALQ 3.7 é o mais promissor para o controle de $S$. frugiperda no Estado de São Paulo. Este isolado possui as toxinas Cry1Ac, Cry1C e CryD.

- As toxinas Cry1 estão presentes na maioria dos isolados testados para o controle da lagarta-do-cartucho.

- Ocorre diferença na suscetibilidade ao Bt entre as populações de $S$. frugiperda.

- Os resultados de eficiência do isolado ESALQ 3.7 em laboratório diferem do obtido em casa-de-vegetação e campo.

- Ocorre efeito subletal de alguns isolados de $B t$ sobre os parâmetros biológicos de $S$. frugiperda (peso de lagartas, peso de pupas fêmeas, oviposição e fecundidade dos ovos). 
- A persistência do Dipel é maior em campo, porém sua meia vida foi inferior. A avaliação da persistência do isolado ESALQ 3.7 em campo e casade-vegetação é afetada, principalmente, por fatores bióticos e abióticos que prejudicam o patógeno.

- $\mathrm{Na}$ interação entre $\mathrm{Bt}$ e demais agentes biológicos visando ao controle da lagarta-do-cartucho ocorre interação positiva com Heterorhabditis sp., negativa para $B$. bassiana e negativa e positiva com o VPN. 


\section{REFERÊNCIAS BIBLIOGRÁFICAS}

ABBOTT, W.S. A method of computing the effectiveness insecticide. Journal of Economic Entomology, v.18, p.265-267, 1925.

ABDUL-SATTAR, A.A.; WATSON, T.F. Effects of Bacillus thuringiensis var kurstaki on tabacco budworm (Lepidoptera: Noctuidae) adult and egg stage. Journal of Economic Entomology, v.75, n.4, p.596-598, 1982.

AGAISSE, H.; LERECLUS, D. How does Bacillus thuringiensis produce so much insecticidal crystal protein? Journal of Bacteriology, v.177, n.21, p.6027-6032, 1995.

ALVES, S. B. Patologia e controle microbiano: vantagens e desvantagens. In: ALVES, S. B. (Ed.). Controle microbiano de insetos. Piracicaba: FEALQ, 1998. cap. 1, p.21-38.

ALVES, S.B. Fungos entomopatogênicos. In: ALVES, S.B. (Ed.). Controle microbiano de insetos. 2. ed. Piracicaba: FEALQ, 1998. cap. 11, p. 289-382.

ALVES, S. B.; LECUONA, R.E. Epizootiologia aplicada ao controle microbiano. In: ALVES, S. B. (Ed.). Controle microbiano de insetos. Piracicaba: FEALQ, 1998. cap. 5, p.97-170. 
ALVES, S.B.; MORAES, S.B. Quantificação de inóculo de patógenos de insetos. In: ALVES, S.B. (Ed.). Controle microbiano de insetos. 2.ed. Piracicaba: FEALQ, 1998. cap. 23, p.765-778.

AMEEN, A. O.; FUXA, J.R.; RICHTER, A.R. Antagonism between formulations of different Bacillus thuringiensis subspecies in Heliothis virescens and Helicoverpa zea (Lepidoptera: Noctuidae). Journal of Entomological Science, v.33, n.2, p.129-134, 1998.

ANDRADE, F.G.; NEGREIRO, M.C.C.; CORTEZ, M.M.; SILVA, V.B.; MOSCARDI, F.; FALLEIROS, A.M.F. Detecção de copos de oclusão de Baculovirus anticarsia na hemolinfa de Anticarsia gemmatalis (Lepidoptera: Noctuidae). In: SIMPÓSIO DE CONTROLE BIOLÓGICO, 8., São Pedro, 2003. Livro de Resumos. São Pedro: Sociedade Entomológica do Brasil, 2003. p.67.

ARANDA, E.; SÁNCHES, J.; PEFEROEN, N.; GUERECA, L.; BRAVO, A. Interaction of Bacillus thuringiensis crystal protein with the midgut epithelial cells of Spodoptera frugiperda (Lepidoptera: Noctuidae). Journal of Invertebrate Pathology, v.68, n.3, p.203-212, 1996.

ARANGO, J. A.; ROMERO, M.; ORDUZ, S. Diversity of Bacillus thuringiensis strains from Colombia with insecticidal activity against Spodoptera frugiperda (Lepidoptera: Noctuidae). Journal of Applied Microbiology, v.92, n.8, p. 466-474, 2002.

ARONSON, A. I.; SHAI, Y. Why Bacillus thuringiensis insecticidal toxins are so effective: unique features of their mode of action. FEMS Microbiology Letters, v.195, n.1, p.1-8, 2001. 
ASHLEY, T. R. Classification and distribution of fall armyworm parasites. Florida Entomologist, v.62, n.1, p.114-123, 1979.

ÁVILA, C.J.; DEGRANDE, P.E.; GOMES, S.A. Insetos-pragas: reconhecimento, comportamento, danos e controle. EMBRAPA-CPAO. Circular Técnica, 5, n.s. p.157-181, 1997.

BAtista FILHO, A.; ALVES, S. B.; ALVES, L. F. A.; PEREIRA, R.M.; AUGUSTO, N.T. Formulação de entomopatógenos. In: ALVES, S.B. (Ed.). Controle microbiano de insetos. 2.ed. Piracicaba: FEALQ, 1998. cap. 25, p. 917-966.

BAUR, M.E.; KAYA, H.K.; TABASHNIK B.E.; CHILCUTT, C.F. Suppresion of diamothback moth (Lepidoptera: Plutellidae) with na entomopathogenic nematode (Rhabditida: Steinernematidae) and Bacillus thuringiensis Berliner. Journal of Economic Entomology, v.91, n.5, p.1089-1095, 1999.

BEDDING, R.A. Low cost in vitro mass production of Neoaplectana and Heterorhabditis species (Nematoda) for field control of insect pests. Nematologica, v. 27, n.1, p. 109-114, 1981.

BEEGLE, C. B.; YAMAMOTO, T. Invitation paper (C.P. Alexander Fund): History of Bacillus thuringiensis Berliner research and development. The Canadian Entomologist, v.124, n.3, p.587-616, 1992.

BEN-DOV, E.; SAXENA, D.; WANG, Q.; MANASHEROB, R.; BOUSSIBA, S.; ZARISTSKY, A. Ingested particles reduce susceptibility of insect larvae to Bacillus thuringiensis. Journal of Applied Entomology, v.27, n.1, p.146-152, 2003. 
BEN-DOV, E.; ZARITSKY, A.; DAHAN, E. Extended screening by PCR for seven group cry genes from field-collected strains of Bacillus thuringensis. Applied and Environmental Microbiology, v. 63, n.12, p.4883-4890, 1997.

BENZ G. Synergism of micro-organisms and chemical insecticides. In: BURGES, H.D.; HUSSEY, N.W. (Ed.). Microbial control of insects and mites. Londres: Academic Press, 1971. cap. 14, p.327-356.

BENZ, G. Environment. In: FUXA, J.R.; TANADA, Y. (Ed.). Epizootiology of insect diseases. New York: Wiley, 1987. cap. 13: p. 177-214.

BERNHARD, K.; JARRET, P.; MEADOWS, M. Natural isolates of Bacillus thuringiensis: worldwide distribution, characterization, and activity against insects pests. Journal of Invertebrate Pathology, v.70, n.1, p.59-68, 1997.

BERTELS, A. Estudos da influência da umidade sobre a dinâmica de flutuação de lepidópteros, pragas do milho. Pesquisa Agropecuária Brasileira, v.5, n.1, p.67-79, 1970.

BIANCO, R. Pragas e seu controle. In. FUNDAÇÃO INSTITUTO AGRONÔMICO DO PARANÁ, A cultura do milho no Paraná. Londrina, 1991. p.185-221. (IAPAR. Circular, 29).

BOHOROVA, N.; MACIEL, A.M.; BRITO, R.M.; AGUILLART, L.; IBARRA, J.E.; HOISINGTON, D. Selection and characterization of mexican strains of Bacillus thuringiensis active against four major lepidopteran maize pests. Entomophaga, v.41, n.2, p.153-165, 1996. 
BOHOROVA, N.; CABRERA, M.; ABARCA, C.; QUINTERO, R.; MACIEL, A.M.; BRITO, R.M.; HOISINGTON, D. BRAVO. A. Susceptibility of four tropical lepidopteran maize pests to Bacillus thuringiensis Cryl-type insecticidal proteins. Journal of Economic Entomology, v.90, n.2, p.412-415, 1997.

BOURQUE, S.N.; VALÉRO, J.R.; MERCIER, J.; LAVOIE, M.C.; LEVESQUE, R. Multiplex polymerase chain reaction for detection and differentiation of the microbial insecticide Bacillus thuringiensis. Applied and Environmental Microbiology, v. 59, n.2, p.523-527, 1993.

BRAVO, A.; SARABIA, S.; LOPEZ, L.; ONTIVEROS, H.; ABARCA, C.; ORTIZ, A.; ORTIZ, M.; LINA, L.; VILLALOBOS, F.J.; PENA, G.; NUNEZVALDEZ, M.E.; SOBERON, M.; QUINTERO, R. Characterization of cry genes in a Mexican Bacillus thuringiensis strain collection. Applied and Environmental Microbiology, v. 64, n.12, p.4965-4972, 1998.

BRETT, C.H.; BASTIDA, R. Resistance of sweet corn varieties to the fall armyworm, Laphygma frugiperda. Journal of Economic Entomology, v.56, n.2, p.162-167, 1963.

BROWNBRIDGE, M.; ONYANGO, J. Screening of exotic and locally isolated B. thuringiensis (Berliner) strains in Kenya fot toxicity to the spotted stem borer, Chilo partellus (Swinhoe). Tropical Pest Management, v.38, n.1, p.77-91, 1992.

BURGES, H. D.; HURST, J. A. Ecology of Bacillus thuringiensis in storage moths. Journal of Invertebrate Pathology, v.30, n.2, p.131-139, 1977. 
BURTON, R.L.; PERKINS, W.D. WSB, a new laboratory diet for the corn earworm and the fall armyworm. Journal of Economic Entomology, v.65, n.2, p.385-386, 1972.

CANTWELL, G. E.; FRANKLIN B. A. Inactivation by irradiation of Bacillus thuringiensis var. thuringiensis. Journal of Invertebrate Pathology, v.8, n.3, p. 256-258, 1966.

CAROZZI, N. B.; KRAMER, V. C.; WARREN, G. W.; EVOLA, S.; KOZIEL, M. G. Prediction of insectidical activity of Bacillus thuringiensis strains by polimarase chain reaction product perfiles. Applied and Environmental Microbiology, v.57, n.11, p. 3057-3061, 1991.

CARVALHO, R.P.L. Danos, flutuação populacional, controle e comportamento de Spodoptera frugiperda (J.E. Smith, 1797) e suscetibilidade de diferentes genótipos de milho em condições de campo. Piracicaba, 1970. 170p. Tese (Doutorado) - Escola Superior de Agricultura "Luiz de Queiroz", Universidade de São Paulo.

CARVALHO, A.O.R. Pragas e seu controle. In: FUNDAÇÃO INSTITUTO AGRONÔMICO DO PARANÁ, O milho no Paraná. Londrina, 1982. p.141-148. (IAPAR. Circular, 68).

CASTANHEIRA, R. S.; MUNHOZ, E. R. B.; COUTO, G. P. Influencia da adubacao do milho (Zea mays L.) sobre a eficiência da Beauveria bassiana (Bals.) Vuill., no controle da Spodoptera frugiperda (J. E. Smith, 1797). Ecossistema, v.18, n.2, p.119-129, 1993. 
CERÓN, J.; ORTíZ, A.; QUINTERO, R.; GUERECA, L. BRAVO, A. Specific PCR primers directed to identify cryl and crylll genes within a Bacillus thuringiensis strain collection. Applied and Environmental Microbiology, v. 61, n.11, p. 3826-3831, 1995.

CERÓN, J.; COVARRUBIAS, L.; QUINTERO, R.; ORTIZ, A.; ORTIZ, M.; ARANDA, E.; LINA, L.; BRAVO, A. PCR analysis of the cryl insecticidal crystal family genes from Bacillus thuringiensis. Applied and Environmental Microbiology, v. 60, n.1, p. 353-356, 1994.

CHAK, K.F.; CHAO, D.C.; TSENG, M.Y.; KAO, S.S.; TUAN, S.J.; FENG. T.Y. Determination and distribution of cry-type genes of Bacillus thuringiensis isolates from Taiwan. Applied and Environmental Microbiology, v.60, n.7, p. 2415-2420, 1994.

CHANG, J. H.; CHOI, J. Y.; JIN, B. R.; ROH, J. Y.; OLSZEWSKI, J. A.; SEO, S. J.; O'REYLLY, D. R.; JE, Y. H. As improved baculovirus insecticide producing occlusion bodies that contain Bacillus thuringiensis insect protein. Journal of Invertebrate Pathology, v.84, n. 1 , p. $30-37,2003$

CHILCOTT, C.N.; WIGLEY, P. J. Isolation and toxicity of $B$. thuringiensis from soil and insect habitats in New-Zealand. Journal of Invertebrate Pathology, v.61, n.3, p.244-247, 1993.

CHONAY, M. F. C. Determinacion de la patogenicidad del entomopatogeno Beauveria bassiana (Bals.) Vuill en 20 especies de insectos plaga en condiciones de laboratorio y su efecto a nivel de campo en Pieris sp. Guatelamala, 1988. 23p. Tese (Mestrado) - Universidade de São Carlos. 
COOPLANTIO. Lagarta-do-cartucho ou lagarta-militar, Spodoptera frugiperda (Lep., Noctuidae). Disponível em: http://www.cooplantio.com.br/scripts/cooplantio/pg. ( 06 de ago. 2003).

COPPING, L. G.; MENN, J.J. Review biopesticides: a review of their action, applications and efficacy. Pest Management Science, v.56, n.5, p.651$676,2000$.

CORREIA, A.C.B. Efeito de Bacillus thuringiensis Berliner sobre parâmetros biológicos de Spodoptera frugiperda (Smith \& Abbot, 1797). In: CONGRESSO BRASILERO DE ENTOMOLOGIA, 10., Rio de Janeiro, 1986. Anais. Rio de Janeiro: Sociedade Brasileira de Entomologia, 1986. p.95.

COSTA, S. D.; BARBERCHECK, M .E.; KENNEDY, G, G. Mortality of colorado potato beatle (Leptinotarsa decemlineata) after sublethal stress with the CryllIA $\delta$-endotoxin of Bacillus thuringiensis and subsequent exposure to Beauveria bassiana. Journal of Invertebrate Pathology, v. 77, n.3, p.173-179, 2001.

$\mathrm{COUCH}$, T. L.; IGNOFFO, C. M. Formulation of insect pathogens. In: BURGES, H. D. (Ed.). Microbial control of pests and plant diseases. London: Academic Press, 1981. p. 621-634.

CRICKMORE, N.; ZEIGLER, D. R.; FEITELSON, J.; SCHNEPF, E.; VAN RIE, J.; LEREClUS, D.; BAUM, J.; DEAN, D. H. Revision of the nomenclature for the Bacillus thuringiensis pesticidal crystal proteins. Microbiology and Molecular Biology Reviews, v.62, n.3, p.807-813, 1998. 
CRUZ, I. Impact of fall armyworm, Spodoptera frugiperda (Smith and Abbot, 1797), on grain yield in field corn. Lafayette, 1980. 162p. Dissertation (M.S.) - Purdue University.

CRUZ, I. A lagarta-do-cartucho na cultura do milho. Sete Lagoas: Embrapa, 1995. 45p.

CRUZ, I.; FIGUEIREDO, M.L.C.; OLIVEIRA, V.C. Effect of a nuclear polyhedrosis virus of Spodoptera frugiperda larvae, its damage and yield of maize crop at different egg mass infestation levels. In: INTERNATIONAL CONGRESS OF ENTOMOLOGY, 21., Foz do Iguaçu, 2000. Abstratcs. Londrina: Embrapa Soja, 2000. v.1, p.382.

CRUZ, I.; TURPIN, F.T. Efeito de Spodoptera frugiperda em diferentes estágios de crescimento da cultura de milho. Pesquisa Agropecuária Brasileira, v.17, n.3, p.355-359, 1982.

CRUZ, I.; FIGUEIREDO, M.L.C.; VAliCENTE, F.H.; OLIVEIRA, A.C. Application rate trials with a nuclear polyhedrosis virus to control Spodoptera frugiperda (Smith) on maize in Brazil. In: SIMPÓSIO DE CONTROLE BIOLÓGICO, 5., Foz do Iguaçu, 1996. Anais: Sessão de Pôsteres. Londrina: Embrapa Soja, 1996. p.169.

CRUZ, I., FIGUEIREDO, M. L. C., OliveirA, A. C., VASCONCElOS, C. A. Damage of Spodoptera frugiperda (Smith) in different maize genotypes cultivated in soil under three levels of aluminium saturation. International Journal of Pest Management, v.45, n.4, p.293-296, 1999. 
CRUZ, I.; VALICENTE, F. H.; SANTOS, J. P. dos ; WAQUIL, J. M.; VIANA, $P$. A. Manual de identificação de pragas da cultura do milho. Sete Lagoas: EMBRAPA/CNPMS, 1997, 67 p.

DAMGAARD, P.H. Natural occurrence and dispersal of Bacillus thuringiensis in the environment. In: CHARLES, J.F.; DELÉCLUSE, A.; NIELSEN-LE ROUX, C. (Ed.). Entomopathogenic bacteria: from laboratory to field application. Netherlands: Kluwer Academic Publishers, 2000. p.23-40.

DELUCCA, A.J.; SIMONSON, J.G.; LARSON, A.D. Bacillus thuringiensis distribution in soils of the United States. Canadian Journal of Microbiology, v.27, n.12, p.865-870, 1981.

DIAS, J.M.C.de S. Produção e utilização de bioinseticidas bacterianos. Pesquisa Agropecuária Brasileira, v.27, n.1, p.59-76, 1992.

DIAS, S.C.; SAGARDOY, M.A.; SILVA, S.F.; DIAS, J.M.C.S. Characterization and pathogenic evaluation of Bacillus thuringiensis and Bacillus sphaericus isolates from argentinean soils. BioControl, v.44, n.1, p.59-71, 1999.

DIEZ-RODRIGUES, G.I.; OMOTO, C. Herança da resistência de Spodoptera frugiperda (J.E. Smith) (Lepidoptera: Noctuidae) à lambdacialotrina. Neotropical Entomology, v.30, n.2, p.311-316, 2001.

DONOVAN, W.P.; GONZALES, J.M. JUNIOR.; GILBERT, M.P. Isolation and characterisation of EG2158, a new strain of Bacillus thuringiensis toxic to coleopteran larvae, and nucleotid sequence of the toxic gene. Molecular and General Genetics, v.58, n.10, p.1344-1350, 1988. 
DULMAGE, H.T.; RHODES, R.A. Production of pathogens in artificial media. In: BURGES, H.D.; HUSSEY, N.W. (Ed.). Microbial control of insects and mites. London: Academic Press, 1973. cap. 24, p.507-540.

DUNKLE, R. L.; SHASHA, B.S. Strach-encapsulated Bacillus thuringiensis: a potential new method for increasing environmental stability of entomopathogens. Environmental Entomology, v.17, n.1, p.120-126, 1988.

EL-MAGHRABY, M. M. A.; HEGAG, A.; YOUSIF KHALIL, S. I. Interactions between Bacillus thuringiensis Berl., Beauveria bassiana (Bals.) Vuill. and the host/parasitoid system Spodoptera littoralis (Boisd.)/Microplitis rufiventris Kok. Journal of Applied Entomology, v.106, n.3, p.417-421, 1998.

ELY, S. The engineering of plants to express Bacillus thuringiensis $\delta$ endotoxins. In: ENTWISTLE, P. F.; CORY, J. S.; BAILEY, M. J.; HIGGS, S. (Ed.). Bacillus thuringiensis, an environmental biopesticide: theory and practice. Chichester: John Willey, 1993. cap. 5, p.105-124.

FANCELLI, A.L. Exigências climáticas e fenologia do milho. Piracicaba: FEALQ, 1990. 16p.

FATORETTO, J. C. Associação de bioensaio e caracterização molecular para seleção de isolados de Bacillus thuringiensis efetivos contra Spodoptera frugiperda. Jaboticabal, 2002. 105 p. Monografia (Graduação) - Faculdade de Ciências Agrárias e Veterinárias, Universidade Estadual Paulista "Julio de Mesquita Filho". 
FERRANDIS, M. D.; JUÁREZ-PERES, V.M.; FRUTOS, R. Distribution of cryl, cryll and crylV genes within Bacillus thuringiensis isolates from Spain. Systematic Applied Microbiology, v.22, n.1, p.179-185, 1999.

FERRAZ, M.C.V.D. Determinação das exigências térmicas de Spodoptera frugiperda (J.E. Smith, 1797) (Lepidoptera, Noctuidae) em cultura de milho. Piracicaba, 1982. 81p. Tese (Mestrado) - Escola Superior de Agricultura "Luiz de Queiroz", Universidade de São Paulo.

FERRAZ, L. C. C. B. Nematóides entomopatogênicos. In: ALVES, S.B. (Ed.). Controle microbiano de insetos. 2.ed. Piracicaba: FEALQ, 1998. p.541-570.

FORCADA, C.; ALCÁCER, E.; GARCERÁ, M.D. Differences in the midgut proteolytic activity on two Heliothis virescens strains, one susceptible and one resistant to Bacillus thuringiensis toxins. Archives on Insect Biochemestry and Physiology, v.32, n.2, p.257-272, 1996.

FORSYTH, G.; LOGAN, N. A. Isolation of Bacillus thuringiensis Northern Victoria Land, Antarctica. Letters in Applied Microbiology, v.30, n.2, p.263-266, 2000.

FRANÇA, M. M.; TIGANO, M. S.; CARVALHO, R. S. Suscetibilidade de $S$. frugiperda aos fungos entomopatogênicos $B$. bassiana e Nomuraea rileyi. In: CONGRESSO BRASILEIRO DE ENTOMOLOGIA, 12., Belo Horizonte, 1989. Resumos. Belo Horizonte: EMBRAPA, 1989. p. 254. 
GALLO, D., O. HAKANO, S. SiLVEIRA NETO, R. P. L. CARVALHO, G. C. DE BAPTISTA, E. BERTI FILHO, J. R. P. PARRA, R. A. ZUCCHI, S. B. ALVES, J. D. VENDRAMIM, L. C. MARCHINI, J. R. S. LOPES, C. OMOTO. Entomologia Econômica. Piracicaba: FEALQ, 2002. 920 p.

GARCIA, M. A.; SIMÕES, M.; HABIB, M.E.M. Possible reasons of resistance in larvae of Spodoptera frugiperda (Abbot \& Smith, 1797) infected by Bacillus thuringiensis var. kurstaki. Revista de Agricultura, v.57, n.2, p.215-222, 1982.

GARCZYNSKY, S.F.; ADANG, M.J. Investigations of Bacillus thuringiensis Cry1 toxin receptor structure and function. In: CHARLES, J.F.; DELÉCLUSE, A.; NIELSEN-LE ROUX, C. (Ed.). Entomopathogenic bacteria: from laboratory to field application. Netherlands: Kluwer Academic Publishers, 2000. p.181-197.

GARDNER, W.A.; FUXA, J.R. Pathogens for the supression of the fall armyworm. Florida Entomologist, v.63, n.4, p.439-447, 1980.

GARDNER, W.A.; NOBLET, R.; SCHWEHR, R. The potential of microbial agents in managing populations of the fall armyworm (Lepidoptera: Noctuidae). Florida Entomologist, v.67, n.3, p.325-332, 1984.

GASSEN, D. Pragas associadas à cultura do milho. Passo Fundo: Aldeia Norte, 1994. 92p. 
GELERNTER, W.; SCHWAB, G. E. Transgenic bacteria, viruses, algae and other microorganims as Bacillus thuringiensis toxin delivery sistems. In: ENTWISTLE, P. F.; CORY, J. S.; BAILEY, M. J.; HIGGS, S. (Ed.). Bacillus thuringiensis, an environmental biopesticide: theory and practice. Chichester: John Willey, 1993. cap. 4, p. 89-104.

GERK, A. O.; KITAJIMA, E. W.; SOUZA, M. L. Identificação e caracterização do isolado brasileiro do vírus de poliedrose nuclear da lagarta do cartucho do milho. Anais da Sociedade Entomológica do Brasil, v.26, n.3, p.507-515, 1997.

GLEAVE, A.P.; WILLIAMS, R.; HEDGES, R. J. Screening by polimerase chain reaction of Bacillus thuringiensis serotypes for the presence of cryV-like insecticidal protein genes and characterization of a CryV gene cloned from B. thuringiensis subsp. kurstaki. Applied and Environmental Microbiology, v.69, n.5, p.1683-1687, 1993.

GLADSTONE, S. Prueba del hongo entomopatogeno Nomuraea rileyi (Farlow) Samson, para el control de cogollero Spodoptera frugiperda (J. E. Smith) en maiz de riego sembrado en epoca seca. Revista de la Escuela de Sanidad Vegetal, v.1, n.2, p.10-13, 1989.

GLARE, T. R.; O'CALLAGHAN, M. Bacillus thuringiensis: biology, ecology and safety. Chichester: John Wiley, 2000. 350 p.

GÓMEZ, I.; OLTEANS, D. I.; GILL, S.S.; BRAVO, A.; SOBERÓN, M. Mapping the epitope in cadherin-like receptors involved in Bacillus thuringiensis Cry1a toxin interaction using phage display. The Journal of Biological Chemestry, v.276, n.31, p.28906-28912, 2001. 
GONZÁLES, J. M. J.; BROWN, B. S.; CARLTON, B. C. Transfer of Bacillus thuringiensis to Bacillus cereus. Proceedings of the National Academic of Science, v. 79, n.10, p.6951-6955, 1982.

GRAVENA, S. Controle biológico no manejo integrado de pragas. Pesquisa Agropecuária Brasileira, v.27, n.3, p.281-300, 1992.

GRIEGO, V. M.; SPENCE, K. D. Inactivation of Bacillus thuringiensis spores by ultraviolet and visible light. Applied and Environmental Microbiology, v.35, n.2, p. 906-910, 1978.

HABIB, M. E. E. M.; PATEL, P. N. Patogenicidade de Nomuraea rileyi (Farlow) Samson em larvas de Spodoptera frugiperda (J. E. Smith, 1797), praga de milho. Revista de Agricultura, v.65, n.1, p.83-90, 1990.

HABBIB, M.E.E.M.; FERRAZ, J.M.G.; OLIVEIRA, G.G. Avaliação de uma nova formulação de Bacillus thuringiensis var. kurstaki em larvas de Spodoptera frugiperda (J.E Smith, 1797). In: CONGRESSO BRASILEIRO DE ENTOMOLOGIA, 11., Salvador, 1987. Anais. Salvador: Sociedade Brasileira de Entomologia, 1987, p.218.

HADDAD, M.L. Utilização do Polo-PC para análise de Probit. In: ALVES, S.B. (Ed.) Controle microbiano de insetos. 2. ed. Piracicaba: FEALQ, 1998. cap. 34. p.999-1014.

HANSEN, B.M.; SALAMITOU, S. Virulence of Bacillus thuringiensis In: CHARLES, J.F.; DELÉCLUSE, A.; NIELSEN-LE ROUX, C. (Ed.). Entomopathogenic bacteria: from laboratory to field application. Netherlands: Kluwer Academic Publishers, 2000. p.41-64. 
HERNANDEZ, J. L. L. Évaluation de la toxicité de Bacillus thuringiensis sur Spodoptera frugiperda. Entomophaga, v.32, n.2, p.163-171, 1988.

HOFTE, H.; WHITELEY, H. R. Insecticidal crystal proteins of Bacillus thuringiensis. Microbiological Reviews, v. 53, n.3, p.242-255, 1989.

HONGYU, Z.; ZINIU, Y.; WANGXI, D. Isolation, distribution and toxicity of Bacillus thuringiensis from warehouses in China. Crop Protection, v.19, n.3, p.449-454, 2000.

HOSSAIN, M.A.; AHMED, S.; HOQUE, S. Abundance and distribution of Bacillus thuringiensis in the agricultural soil of Bangladesh. Journal of Invertebrate Pathology, v.70, n.3, p.221-225, 1997.

IGNOFFO, C.M.; GARCIA, C.; KROHA, M.J.; HOFFMAN, J.D. Effects of bacteria and a fungus fed singly or in combination on mortality lavae of cabbage looper (Lepidoptera: Noctuidae). Journal of the Kansas Entomological Society, v.53, n.3, 797-800, 1980.

INSTITUTO BRASILEIRO DE GEOGRAFIA E ESTATÍSTICA. Levantamento Sistemático da Produção Agrícola. www.ibge.gov.br. (05 jan. 2004).

JAQUES, R.P.; MORRIS, O.N. Compatibility of pathogens with other methods of pest control and with different crops. In: BURGES, E.D. (Ed.). Microbial Control of Pest and Plant Diseases 1970-1980. London: Academic Press, 1981. p.695-715. 
JOHNSON, C.; BISHOP, A.H. A technique for the effective enrichment and isolation of Bacillus thuringiensis. FEMS Microbiology Letters, v.142, n.1, p.173-177,1996.

JUNG, Y. C.; KIM, S.U.; CÔTE, J.C.; LECADET, M.M.; CHUNG, Y.S.; BOK, S.H. Characterization of a new Bacillus thuringiensis subsp. higo strain isolated from rice bran in Korea. Journal of Invertebrate Pathology, v.71, n.1, p.95-96, 1998.

KAUR, S.; SINGH, A. Natural occurrence of Bacillus thuringiensis in legominous phylloplanes in the New Dehli region of India. World Journal of Microbiology and Biotechnology, v. 16, n.3, p. 679-682, 2000.

KLIER, A.; BOURGOUIN, C.; RAPPOPORT, G. Mating between Bacillus subtilis and Bacillus thuringiensis and transfer of cloned crystal genes. Molecular and General Genetics, v.191, n.2, p.257-262, 1983.

KNIPLING, E. F. Regional management of the fall armyworm - a realistic approch? Florida Entomologist, v.63, n.4, p.468-480, 1980.

KNOWLES, B. H. Mechanism of action of Bacillus thuringiensis insecticidal $\delta$-endotoxins. Advances in Insect Physiology, v.24, n.2, p.275-308, 1994.

KOPPENHOFER, A. M.; KAYA, H. K. Additive and synergistic interaction between entomopathogenic nematodes and Bacillus thuringiensis for scarab grup control. Biological Control, v.8, n.2, p.131-137, 1997. 
KOPPENHOFER, A. M.; CHOO, H. Y.; KAYA, H. K.; LEE, D.W.; GELERNTER, W.D. Increased field and greenhouse efficacy against scarab grups with a combination of an entomopathogenic nematode and Bacillus thuringiensis. Biological Control, v.14, n.1, p.37-44, 1999.

KOZIEL, M. G.; BELAND, G. L.; BOWMAN, C.; CAROZZI, N.B.; CRENSHAW, R.; CROSSLAND, L.; DAWSON, J.; DESAI, N.; HILL, M.; KADWELL, S.; LAUNIS, K.; LEWIS, K.; MADDOX, D.; McPHERSON, K.; MEGHJI, M.R.; MERLIN, E.; RHODES, R.; WARREN, G.W.; WRIGHT, M.; EVOLA, S.V. Field performance of elite transgenic maize plants expressing and insecticidal protein derived from Bacillus thuringiensis. Biotechnology, v.11, n.2, p.194-200, 1993.

KRIEG, A. Interactions between pathogens. In: BURGES, H.D.; HUSSEY, N.W. (Ed.). Microbial control of insects and mites. Londres: Academic Press, 1971 cap. 21, p.459-468.

LECADET, M. M.; FRACHON, E.; DUMANOIR V.C.; RIPOUTEAU, H.; HAMON, S.; LAURENT, P.; THIERY, I. Updating the H-antigen classification of Bacillus thuringiensis. Journal of Applied Microbiology, v.86, n.3, p.660-672, 1999.

LECUONA, R. Microbial control with entomopathogenic fungi in Argentina. Revista de la Sociedad Entomologica Argentina, v.58, n.1/2, p.301306, 1999.

LEE, M. K.; CURTISS, S. ALCANTARA, E.; DEAN, H. Synergistic effect of the Bacillus thuringiensis toxins CrylAa and CrylAc on the gypsy moth, Lymantria dispar. Applied and Environmental Microbiology, v.62, n.2, p.583-586, 1996. 
LEIDERMAN, L.; SAUER, H.F.G. A lagarta dos milharais Laphygma frugiperda (Abbot e Smith, 1797). O Biológico, v.19, n.6, p.105-113, 1953.

LEITE, L.G.; MACHADO, L.A.; BATISTA FILHO, A. Potencial para produção e uso de nematóides entomopatogênicos para o controle de pragas e necessidade de pesquisas no Brasil. In: SIMPÓSIO DE CONTROLE BIOLÓGICO, 8., São Pedro, 2003. Livro de Resumos. São Pedro: SEB, 2003. p.51.

LERECLUS, D.; DELECLUSE, A.; LECADET, M. M. Diversity of Bacillus thuringiensis toxins and genes. In: ENTWISTLE, P. F.; CORY, J.S.; BAILEY, M.; HIGGS, S. (Eds.). Bacillus thuringiensis an environmental biopesticide: theory and practice. Chichester: John Wiley, 1993. p.37-70.

LEUCK, D.B.; PERKINS, W.D. A method of estimating the fall armyworm progeny reduction when evaluating control achieved host-plant resistance. Journal of Economic Entomology, v.65, n.4, p. 482-483, 1972.

LEZAMA, G. R.; ALATORRE, R. R.; BODAJIL, J. L. F. Virulencia de cinco cepas de los hongos entomopatogenos contra Spodoptera frugiperda (Lepidoptera: Noctuidae) en huevos y larvas neonatas. Revista Internacional de Control Biologico, v.3, n.1, p.35-39, 1996.

LEWIS, L.C.; BING, L.A. Bacillus thuringiensis Berliner and Beauveria bassiana (Balsamo) Vuillimen for european corn borer control: program for immediate and season-long supression. The Canadian Entomologist, v.123, n.2, p.387-393, 1991. 
LI, J.; CARREL, J.; ELLAR, D. J. Cristal structure of insecticide deltaendotoxina from Bacillus thuringiensis at 2,5 A resolution. Nature, v.353. n.7, p.815-821, 1991.

LIMA, J.O.G. de; ZANUNCIO, J.C. Controle da "lagarta do cartucho do milho", Spodoptera frugiperda, pelo carbaril, carbofuram, dipel (Bacillus thuringiensis) e endossulfam. Revista Ceres, v.23, n.127, p.222-225, 1976.

LOGUERCIO, L. L., SANTOS, C. G., BARRETO, M. R.; GUIMARÃES, C.T.; PAIVA, E. Association of PCR and feeding bioassays as a large-scale method to screen tropical Bacillus thuringiensis isolates for Cry constitution with higher insecticidal effect against Spodoptera frugiperda (Lepidoptera: Noctuidae) larvae. Letters In Applied Microbiology, v.32, n.1, p.1-6, 2001.

LÓPEZ-EDWARDS, M.; HERNÁNDEZ-MENDOZA, M.J.L.; PESCADORRUBIO, A.P.; MOLINA-OCHOA, J.; LEZAMA-GUTIÉRREZ, R.; HAMM, J.J.; WISEMAN, B.R. Biological differences between five populations of fall armyworm (Lepidoptera: Noctuidae) collected from corn in Mexico. Florida Entomologist, v.82, n.2, p.254, 262, 1999.

LOPEZ-LASTRA, C.C.; BOUCIAS, D.G.; SOARES JÚNIOR., G.C. Bacillus thuringiensis endotoxin effects on Spodoptera exigua and S. Frugiperda larva infected with baculoviruses. Environmental Entomology, v.24, n.2, p.239-242, 1995. 
LORDELLO, A.L.L; LARA. F.M.; PARRA, J.R.P. Preferência para a alimentação de Spodoptera frugiperda (J.E. Smith, 1797) (Lepidoptera Noctuidae) em sorgo, em condições de laboratório. Anais da Sociedade Entomológica do Brasil, v.9, n.2, p.219-241, 1980.

LUCCHINI, F. Biologia de Spodoptera frugiperda (Smith \& Abbot, 1797) (Lepidoptera: Noctuidae). Níveis de prejuízo e avaliação toxicológica de inseticidas para o seu combate em milho. Curitiba, 1977. 114 p. Tese (Mestrado) - Universidade Federal do Paraná.

LUO, K.; BANKS, D.; ADANG, M .J. Toxicity, binding and permeality analyses of four Bacillus thuringiensis Cry $1 \delta$-endotoxinas using brush border membrane vesicles of Spodoptera exigua and Spodoptera frugiperda. Applied and Environmental Microbiology, v.65, n.2, p.457-464, 1999.

LUTHY, P.; WOLFERSBERGER, M. G. Pathogenisis of Bacillus thuringiensis toxins. In: CHARLES, J.F.; DELÉCLUSE, A.; NIELSEN-LE ROUX, C. (Ed.). Entomopathogenic bacteria: from laboratory to field application. Netherlands: Kluwer Academic Publishers, 2000. p.167-180

LYSENKO, O. Bacillus thuringiensis: evolution of a taxonomic conception. Journal of Invertebrate Pathology, v.41, n.2, p.295-298, 1983.

McGUIRE, M.R.; SHASHA, B. S. Sprayable self-encapsulation strach formulations for Bacillus thuringiensis. Journal of Economic Entomology, v.83, n.7, p.1813 -1817, 1989. 
McGUIRE, M.R.; SHASHA, B. S. Sprayable self-encapsulation strach formulations for Bacillus thuringiensis. Journal of Economic Entomology, v.89, n.2, p.863 -869, 1996.

MAEDA, M.; MIZUKI, E.; NAKAMURA, Y. Recovery of Bacillus thuringiensis from marine sediments of Japan. Current Microbiology, v.40, n.6, p.418-422, 2000.

MARTIN, P.A.W.; TRAVERS, R.S. Worldwide abundance and distribution of Bacillus thuringiensis isolates. Applied and Environmental Microbiology, v.55, n.8, p.2437-2442, 1989.

MARTÍNEZ, C.; CABALLERO, P. Contents of cry genes and insecticidal activity of Bacillus thuringiensis strains from terrestrial and aquatic habitats. Journal of Applied Microbiology, v.92, n.3, p.745-752, 2002.

MEADOWS, M. P. Bacillus thuringiensis in the environment: ecology and risk assessment. In: ENTWISTLE, P. F.; CORY, J. S.; BAILEY, M. J.; HIGGS, S. (Ed.). Bacillus thuringiensis, an environmental biopesticide: theory and practice. Chichester: John Wiley, 1993. p.193220.

MEADOWS, M. P. ELLIS, D. J.; BUTT, J.; JARRET, P.; BURGES, H.D. Distribution, frequency, and diversity of Bacillus thuringiensis in an animal feed mill. Applied and Environmental Microbiology, v.58, n.4, p.1344-1350, 1992. 
MELO, M.; SILVA, R.F.P. Influência de três cultivares de milho no desenvolvimento de Spodoptera frugiperda (J.E. Smith, 1797) (Lepidoptera, Noctuidae). Anais da Sociedade Entomológica do Brasil, v.16, n.1, p.37-49, 1987.

MOLINA-OCHOA, J.; HAMM, J.J.; LEZAMA-GUTIERREZ, R.; BOJALILJABER, L.F.; ARENAS-VARGAS, M.; GONZALES, RAMIREZ, M. Virulence of six entomopathogenic nematodes (Steinermatidae and Heterorhabditidae) on immature stages of Spodoptera frugiperda (Lepidoptera: Noctuidae). Vedalia, v.3, n.1, p.25-29, 1996.

MOSCARDI, F. Utilização de vírus entomopatogênicos em campo. In: ALVES, S.B. (Ed.). Controle microbiano de insetos. 2.ed. Piracicaba: FEALQ, 1998. cap. 15, p. 509-540.

MOSCARDI, F.; KASTELIC, J. G.; SOSA-GÓMEZ, D. R. Suscetibilidade de três espécies de lepidópteros associados a soja a três isolados do fungo Nomuraea rileyi (Farlow) Samson. Anais da Sociedade Entomológica do Brasil, v.21, n.2, p.93-100, 1992.

MULLIS, K.; FALOONA, F. Specific synthesis of DNA in vitro via a polymerase catalysed chain reaction. Methods in Enzymology, v.55, n. 2, p.335-350, 1987.

NALIM, D. M. biologia, nutrição quantitativa e controle de qualidade das populações de Spodoptera frugiperda (J.E. Smith, 1797) (Lepidoptera: Noctuidae) em duas dietas artificiais. Piracicaba, 1991. 150p. Tese (Doutorado) - Escola Superior de Agricultura "Luiz de Queiroz", Universidade de São Paulo. 
NAVON, A. Bacillus thuringiensis insecticides in crop protection - reality and prospects. Crop Protection, v.19, n.8/10, p.669-676, 2000.

NAVON, A. Bacillus thuringiensis application in agriculture. In: CHARLES, J.F.; DELÉCLUSE, A.; NIELSEN-LE ROUX, C. (Ed.). Entomopathogenic bacteria: from laboratory to field application. Netherlands: Kluwer Academic Publishers, 2000. p.355-367.

NAKANO, O.; SILVEIRA NETO, S.; ZUCCHI, R. A. Entomologia Econômica. São Paulo: Livroceres, 1981. 313p.

OHBA, M.; AIZAWA, K. Distribution of Bacillus thuringiensis in soils of Japan. Journal of Invertebrate Pathology, v.47, n.3, p. 277-282, 1986.

OMOTO, C.; SCHMIDT, F.B.; SILVA, R.B.; ZUCCHI, T.D.; RISCO, M.D.M.; TRAVALINI, C.; THOMAZINI, T.; TAKAKI, S.C. Bases for an insecticide resistance management of Spodoptera frugiperda in corn in Brazil. In: INTERNATIONAL CONGRESS OF ENTOMOLOGY, 21., Foz do Iguaçu, 2000. Abstracts. Londrina: Embrapa Soja, 2000. v.1, p.347.

PANIZZI, A.R.; PARRA, J.R.P. Ecologia nutricional de insetos e suas implicações no Manejo de Pragas. São Paulo: Manole, 1991. 359 p.

PARK, H. W.; DELÉClUSE, A.; FEDERICI, B. A. Constrution and characterization of a recombinant Bacillus thuringiensis subps. Israelensis strain that produces Cry11B. Journal of Invertebrate Pathology, v.78, n.1, p.37-44, 2001.

PARRA, J.R.P.; HADDAD, M.L. Determinação do número de ínstares de insetos. Piracicaba: FEALQ, 1989. 49p. 
PASHLEY, D. P. Current status of fall armyworm host strains. Florida Entomologist, v.71, n.2, p.227-234, 1988.

PEDERSEN, A.; DEDES, J.; GAUTHIER, D.; Van FRANKENHUYZEN, K. Sublethal effects of Bacillus thuringiensis on the spruce budworm, Choristoneura fumiferana. Entomologia Experimentalis et Applicatta, v.83, n.3, p.253-262, 1997.

PEDIGO, L.P. Entomology and pest management. New York: MacMillan, 1989. $646 \mathrm{p}$.

PERÉZ, N.; VASQUÉZ, L. L. Manejo ecológico de plagas. In: F. Funes et al. (Ed.). Transformando el campo cubano. Avances de la agricultura sostenible. La Habana, Cuba: ACTAF, 2001. p.191-226.

PHYLLIS, A. W. M.; TRAVERS, R.J. Worldwide abundance and distribution of Bacillus thuringiensis isolates. Applied and Environmental Microbiology, v.55, n.10, p.2437-2442, 1989.

PILCHER, C. D.; RICE, M. E.; OBRYCKI, J. J. Field and laboratory evaluations of transgenic Bacillus thuringiensis corn on secundary lepidopteran pests (Lepidoptera: Noctuidae). Journal of Economic Entomology, v.90, n.2, p.669-678, 1997.

PINNOCK, D. E.; BRAND, R. J.; MILSTEAD J. E. The field persistence of Bacillus thuringiensis spores. Journal of Invertebrate Pathology, v.18, n.4, p. 405-411, 1971. 
PINNOCK, D. E.; BRAND, R. J.; JACKSON, K. L. The field persistence of Bacillus thuringiensis spores on Cercis occidentalis leaves. Journal of Invertebrate Pathology, v.23, n.4, p. 341-346, 1974.

PINNOCK, D. E.; BRAND, R. J.; MILSTEAD J. E. Effect of three species on the coverage and field persistence of Bacillus thuringiensis spores. Journal of Invertebrate Pathology, v. 25, n.3, p. 209-214, 1975.

POINAR, G.O. Use of nematodes for microbial control of insects. In: BURGES, H.D.; HUSSEY, N.W. (Ed.). Microbial control of insects and mites. Londres: Academic Press, 1971. cap. 8, p.181-204.

PORCAR, M.; CABALLERO, P. Molecular and insecticidal characterization of a Bacillus thuringiensis strain isolated during an natural epizootic. Journal of Applied Microbiology, v. 89, n.4, p.309-316, 2002.

PORCAR, M.; JUARÉZ-PÉREZ, V. PCR-based identification of Bacillus thuringiensis pesticidal crystal genes. FEMS Microbiology Reviews, v.26, n.5, p.419-432, 2003.

PRIEST, F.G. Biodiversity of the entomopathogenic, endospore-forming bacteria. In: CHARLES, J.F.; DELÉCLUSE, A.; NIELSEN-LE ROUX, C. (Ed.). Entomopathogenic bacteria: from laboratory to field application. Netherlands: Kluwer Academic Publishers, 2000. p.1-22.

RAJAGOPAL, D.; MALLIKARJUNAPPA, S.; GOWDA, J. Occurrence of natural enemies of the groundnut leaf miner, Aproaerema modicella Deventer (Lepidoptera: Gelechiidae). Journal of Biological Control, v.2, n.1, p.129-130, 1998. 
RAMACHADRAN, R.; RAFFA, K.F.; MILLER, M.J.; ELLIS, D.D.; McCOWN, B.H. Behavioral responses and sublethal effects of spruce budworm (Lepidoptera: Tortricidae) and fall webworm (Lepidoptera: Arctiidae) larvae to Bacillus thuringiensis Cry $1 \mathrm{Aa}$ toxin in diet. Environmental Entomology, v.22, n.1, p.197-211, 1993.

RAUN, E. S.; JACKSON, R. D. Encapsulation as a technique for formulating microbial and chemical insecticides. Journal of Economic Entomology, v.59, n.3, p.612-622, 1966.

RAUN, E. S.; SUTTER G. R.; REVELO, M. A. Ecological factors affecting the pathogenicity of Bacillus thuringiensis var. thuringiensis to the European corn borer and fall armyworm. Journal of Invertebrate Pathology, v.8, n.4, p.365-375, 1966.

RIBEIRO, C.; DUVIC, B.; OLIVEIRA, P. Insect immunity - effects of factors produced by a nematobacterial complex In immunocompetent cells. Journal of Insect Physiology, v.45, v.3, p.677-685, 1999.

RICE, W. C. Specific primers for the detection of vip3A insecticidal gene within a Bacillus thuringiensis collection. Letters and Applied Microbiology, v.28, n.5, p. 378-382, 1999.

RODRIGUES JÚNIOR, C.; PRATISSOLI, D. Avaliação da patogenicidade de fungos entomopatógenos Beauveria bassiana e Metarhizium anisopliae sobre Spodoptera frugiperda (lagarta do cartucho do milho). In: CONGRESSO BRASILEIRO DE ENTOMOLOGIA, 12., Belo Horizonte, 1989. Resumos. Belo Horizonte: EMBRAPA, 1989. p. 223. 
RODRIGUES JÚNIOR., C.; FERNANDES, O.D.; BOICA JUNIOR, A.L. Controle de Spodoptera frugiperda (Lep., Noctuidae) através de Bacillus thuringiensis $(B t)$ na cultura do milho In: CONGRESSO DE INICIAÇÃO CIENTÍFICA, 2., Botucatu, 1990. Resumos. Botucatu: Universidade Estadual Paulista, 1990, p.178.

SALAMA, H.S.; FODA, M.S.; EL SHARABI, A.; MATTER, M.; KHALAFALLAH, M. Development of some lepidopterous cotton pests affected by exposure to sublethal levels of endotoxins of Bacillus thuringiensis for different periods. Journal of Invertebrate Pathology, v.38, n.3, p.220-229, 1981.

SALAMA, H. S.; MORRIS, O. N. The use of Bacillus thuringiensis in developing countries. In: ENTWISTLE, P. F.; CORY, J. S.; BAILEY, M. J.; HIGGS, S. (Ed.). Bacillus thuringiensis, an environmental biopesticide: theory and practice. Chichester: John Willey, 1993. cap. 11, p.237-253.

SALAMA, H.S.; SHARABY, A.F. Effects of exposure to sublethal doses of Bacillus thuringiensis (Berl.) on the development of the greasy cutworm Agrotis ypsilon (Hufn.). Journal of Applied Entomology, v.106, n.4, p.503-511, 1988.

SALEH, S. M.; HARRIS, R. F.; ALLEN, O. N. Method for determining Bacillus thuringiensis var. thuringiensis Berliner in soil. Canadian Journal of Microbiology, v.15, n.8, p.1101-1104, 1969. 
SAlvadoRI, J. R., QUINTElA, E. D., CORREIA, A. C. B., AlVES, S. B. Efeito de Bacillus thuringiensis sobre parametros biologicos de Spodoptera frugiperda. In: CONGRESSO BRASILEIRO DE ENTOMOLOGIA, 10., Rio de Janeiro, 1986, Anais. Rio de Janeiro - RJ: Sociedade Entomologica do Brasil., 1986. v.1. p. 201.

SAMBROOCK, J.; MINIATIS, T.; FRITSH, E.F. Molecular cloning: a laboratory manual. 2 ed. New York: Cold Sring Harbor, 1989. 250p.

SANCHIS, V.; LERECLUS D.; MENOU, G.; CHAUFAUX, J.; LECADET, M. M. Multiplicity of $\delta$ endotoxinas genes with different insecticidal specificities in Bacillus thuringiensis aizawai 7.29. Molecular Microbiology, v.2, n.2, p.393-404, 1998.

SCHNEPF, E.; CRIKMORE, N.; VAN RIE, J.; LERECLUS, D.; BAUM, J.; FEITELSON, J.; ZEIGLER, D. R.; DEAN, D. H. Bacillus thuringiensis and its pesticidal crystal proteins. Microbiology and Molecular Biology Reviews, v.62, n.3, p.775-806, 1998.

SHAMSELDEAN, M.M.M.; ISMAIL, A.A. Effect of the nematode Heterorhabditis bacteriophora and the bacterium Bacillus thuringiensis as integrated biocontrol agents og the black cutworm. Anzeiger fuer Schaedlingskunde, Pflanzenschutz, Umweltschutz, v.70, n.1, p.7799, 1997.

SIKDAR, D.P.; MAJUMDAR, M.K.; MAJUMDAR, S.K. Effect of minerals on the production of the delta endotoxin by Bacillus thuringiensis subsp. Israelensis. Biotechnology Letters, v.13, n.7, p.511-514, 1991. 
SILOTO, R.C.; ALMEIDA, J.E.M.; RAGA, A. Epizooty of Nomuraea rileyi in Spodoptera frugiperda larvae in the corn crop, Zea mays. . In: CONGRESSO INTERNACIONAL DE ENTOMOLOGIA, 21., Foz do Iguaçu, 2000. Abstracts. Foz do Iguaçu: EMBRAPA, 2000. v.1, p.543.

SILVA, M.T.B.; RUEDELL, J.; CAMPOS, A.E. et al. Bioecologia e efeito de Spodoptera frugiperda (Smith \& Abbot 1797) sobre o rendimento de milho semeado em diversas épocas. In: REUNIÃO TÉCNICA ANUAL DO MILHO, 28., 1983, Porto Alegre. Ata. Porto Alegre: IPAGRO, 1983. p.227.

SILVA, S. F. da.; DIAS, J. M. C. S.; MONNERAT, R. G. Isolamento, identificação e caracterização entomopatogênica de bacilos de diferentes regiões do Brasil. Brasília: Embrapa, 2002a. 4 p. (EMBRAPACenargen, Comunicado Técnico, 70).

SILVA, S. F. da.; DIAS, J. M. C. S.; MONNERAT, R. G. Comparação entre três métodos de isolamento de bacilos entomopatogênicos. Brasília: Embrapa, 2002b. 3 p. (EMBRAPA-Cenargen, Circular Técnica, 14).

SILVA-WERNECK, J. O.; ABREU NETO, J. R. M. V.; TOSTES, A. N.; FARIA, L.O; DIAS, J.M.C.S. Novo isolado de Bacillus thuringiensis efetivo contra a lagarta-do-cartucho. Pesquisa Agropecuária Brasileira, v. 35, n.1, p.221-227, 2000.

SILVEIRA, L.C; VENDRAMIM. J.D.; ROSSETTO, C.J. Efeito de genótipos de milho no desenvolvimento de Spodoptera frugiperda (J.E. Smith). Anais da Sociedade Entomológica do Brasil, v.26, n.2, p.291-298, 1997. 
SILVEIRA NETO, S. Análise fenética. In: ALVES, S.B. (Ed.). Controle microbiano de insetos. São Paulo: Manole, 1986. cap. 22, p. 384-407.

SOARES JÚNIOR., G. G. New products and uses arising from Mycogen's CellCap $^{\circledR}$ biological encapsulation technology. In: SIMPÓSIO DE CONTROLE BIOLÓGICO, 5., Foz do Iguaçu, 1996. Anais: Conferências e Palestras. Foz do Iguaçu: EMBRAPA, 1996. p.178191.

SWIECICKA, I.; FIEDORUK, K.; BEDNARZ, G. The occurrence and properties of Bacillus thuringiensis isolated from free-living animals. Letters in Applied Microbiology, v.34, n.3, p. 194-198, 2002.

TAMEZ-GUERRA, P.; MCGUIRE, M. R.; BEHLE, R. W.; SHASHA, B. S.; WONG, L. J. G. Assessment of microencapsulated formulations for improved residual activiy of Bacillus thuringiensis. Journal of Economic Entomology, v.93, n.2, p.219-225, 2000.

TAMEZ-GUERRA, P.; GALÁN-WONG, L.J.; MEDRANO- ROLDÁN, H.; GARCIA-GUTIÉRREZ, C.; RODRIGUEZ-PADILLA, C.; GOMEZ-FLORES, R. A.; TAMEZ-GUERRA, R.S. Bioinseticidas: su empleo, produción y comercialización en México. Ciencia UANL, v.4, n.2, p.143-152, 2001.

TALALAEV, E. V. Septicemia of the caterpillars of the Siberian silkworm. Mikrobiologiya, v.25, n.1, p.99-102, 1956.

TIGANO, M. M. S.; FARIA, M. R. de.; LECUONA, R. E. Análise da patogenicidade e germinação do fungo Nomuraea rileyi (Farlow) Samson isolado no distrito federal. Anais da Sociedade Entomológica do Brasil, v.24, n.1, p.53-60, 1995. 
TRAVERS, R. S., MARTIN, P. A. W.; REICHEFELDER, C. F. Selective process for efficient isolation soil Bacillus sp. Applied and Environmental Microbiology, v.53, n.10, p.1263-1266, 1987.

UEMURA, T. The cadherin superfamily at synapse: more members, more missions. Cell, v.93, n. 10, p.1095-1098, 1998.

URIBE, D.; MARINEZ, W.; CERÓN, J. Distribution and diversity of cry genes in native strains of Bacillus thuringiensis obtained from different ecosystems from Colombia. Journal of Invertebrate Pathology, v.82, n.2, p.119-127, 2003.

VAECK, M.; REYNAERTS, A.; HOFTE, H.; JANSENS, S.; De BEUKELLER, M.; DEAN, C.; ZABEAU, M. Van MONTAGU, M.; LEEMANS, J. Transgenic plants protected from insect attack. Nature, v.328, n.1, p.3337, 1987.

VALADARES-INGLIS, M. C. C.; SOUZA, M. T.; SHILER. W. Engenharia genética de microrganismos agentes de controle biológico. In: MELO, I. S.; AZEVEDO, J. L. (Ed.). Controle biológico. EMBRAPA: Jaguariúna, 1998. p. 102-225.

VALICENTE, F. H; COSTA, E. F. da. Controle da lagarta do cartucho, Spodoptera frugiperda (J. E. Smith), com o Baculovirus spodoptera, aplicado via água de irrigação. Anais da Sociedade Entomológica do Brasil, v.24, n.1. p.61-67, 1995.

VALICENTE, F.H.; CRUZ, I. Controle biológico da lagarta-do-cartucho, Spodoptera frugiperda, com o baculovírus. Sete Lagoas: Embrapa, 1991. 23p. (EMBRAPA-CNPMS, Circular Técnica, 15). 
VALICENTE, F.H.; PAIVA, E.; VASCONCELOS, M.J.V. Mortalidade de Spodoptera frugiperda por cepas de Bacillus thuringiensis isolados de diferentes regiões do Brasil. In: SIMPÓSIO DE CONTROLE BIOLÓGICO, 5., Foz do Iguaçu, 1996. Anais: Sessão de Pôsteres. Londrina: Embrapa Soja, 1996. p.75.

VALICENTE, F.H.; LOGUERCIO, L.L.; FRANÇA, F.T.; PAIVA, E.; BARRETO, M. Effect of treatment timing of Baculovirus spodoptera and Bacillus thuringiensis on Spodoptera frugiperda. In: CONGRESSO INTERNACIONAL DE ENTOMOLOGIA, 21., Foz do Iguaçu, 2000. Abstracts. Foz do Iguaçu: EMBRAPA, 2000. v.1, p.545.

VAlicente, F. H., Martins, M. F., CARVAlho, C. H. S., PAiva, E. Mortality of Spodoptera frugiperda caused by Bacillus thurigiensis In: SEGUNDO ENCUENTRO LATINO-AMERICANO DE BIOTECNOLOGIA VEGETAL, 1995, Proceedings. Puerto Iguazu. 1995. p. 117.

VALICENTE, F.H.; VASCONCELOS, M.J.V.; PAIVA, E., FARIA, A.; SOUZA, F.; BARRETO, M. Caracterização através da PCR de cepas de Bacillus thuringiensis de diferentes regiões do Brasil. In: SIMPÓSIO DE CONTROLE BIOLÓGICO, 6., Rio de Janeiro, 1998, Anais. Rio de Janeiro: EMBRAPA/FIOCRUZ, 1998. p.164.

Van FRANKENHUYZEN, K. The Challenge of Bacillus thuringiensis. In: ENTWISTLE, P. F.; CORY, J. S.; BAILEY, M. J.; HIGGS, S. (Ed.). Bacillus thuringiensis, an environmental biopesticide: theory and practice. Chichester: John Willey, 1993. cap. 1, p.1-35. 
Van FRANKENHUYZEN, K. Application of Bacillus thuringiensis in forestry. In: CHARLES, J.F.; DELÉCLUSE, A.; NIELSEN-LE ROUX, C. (Ed.). Entomopathogenic bacteria: from laboratory to field application. Netherlands: Kluwer Academic Publishers, 2000. p. 371- 381.

VANNINEN, I.; KOSKULA, H. Biological control of the shore fly (Scatella tenuicosta) with steinernematidae nematodes and Bacillus thuringiensis var. thuringiensis in peat and rockwool. Biocontrol Science and Technology, v.13, n.1, p. 47-63, 2003.

VANKOVA, J.; PURRINI, K. Natural epizootics caused by bacilli of the species Bacillus thuringiensis and Bacillus cereus. Zeitschrift fur Angewandte Entomologie, v.88, n.2, p.216-221, 1979.

WANG, J.; BOETS, A.; VAN RIE, J.; REN. G. Characterization of cry1, cry2 and cry9 genes in Bacillus thuringiensis isolates from China. Journal of Invertebrate Pathology, v.82, n.1, p.63-71, 2003.

WAQUIL, J.M.; VIANA, P.A.; LORDELLO, A.I.; CRUZ, I.; OLIVEIRA, A.C. Controle da lagarta-do-cartucho em milho com inseticidas químicos e biológicos. Pesquisa Agropecuária Brasileira, v.17, n.2, p.163-166. 1982.

WISEMAN, B.R.; DAVIS, F.M; CAMPBELL, J.E. Mechanical infestation device used in fall armyworm plant resistance programs. Florida Entomologist, v.63, n.4, p.425-432, 1980. 
WORLD HEALTH ORGANIZATION. Informal consultation on the development of Bacillus sphaericus as a microbial larvicide. Geneva/ UNDP: World Bank/WHO. 24 p. Special Programme for Research and Training in Tropical Deseases (TDR).

YAMAMOTO, T.; DEAN, D. H. Insecticidal proteins produced by bacteria pathogenic to agriculturas pests. In: CHARLES, J.F.; DELÉCLUSE, A.; NIELSEN-LE ROUX, C. (Ed.). Entomopathogenic bacteria: from laboratory to field application. Netherlands: Kluwer Academic Publishers, 2000. p. 81-100.

YAMVRIAS, C. Contribution à l'étude du mode d'action de Bacillus thuringiensis Berliner vis-à-vis de la teigne de la farine Anagasta (Ephestia) kuehniella Zeller (Lépidoptère). Entomophaga, v.7, n.1, p.101-159, 1962.

YAO, J.; LIU, Y.; GAO, Z.T.; LIU, P.; SUN, M.; ZOU, X.; QU, S.S.; YU, Z.N. Microcalorimetric study on the biological effects of $\mathrm{Zn}^{+2}$ on Bacillus thuringiensis growth. Chinese Journal of Chemistry, v.20. n.4, p.746752, 2002.

YAO, J.; LIU, Y.; GAO, Z.T.; LIU; P., SUN, M.; QU, S. S.; YU, Z. N. A microcalorimetric study of the biologic effect of $\mathrm{Mn}(\mathrm{II})$ on Bacillus thuringiensis growth. Journal of Thermal Analysis and Calorimetry, v.70, n.2, p.415-421, 2002

YU, S.J. Detection and biochemical characterization of insecticide resistance in fall armyworm (Lepidoptera: Noctuidae). Journal of Economic Entomology, v.85, n.3, p.675-682, 1992. 
YU, C. C.; MULLINS, M. A.; WARREN, G. W.; KOZIEL, M. G.; ESTRUCH, J. $J$. The Bacillus thuringiensis vegetative insecticidal protein Vip3A lyses epithelial cells of susceptible insects. Applied and Environmental Microbiology, v.63, n.2, p.532-536, 1997. 